\title{
Questa baseline and pre-mining ground-water quality investigation. 23. Quantification of mass loading from mined and unmined areas along the Red River, New Mexico
}

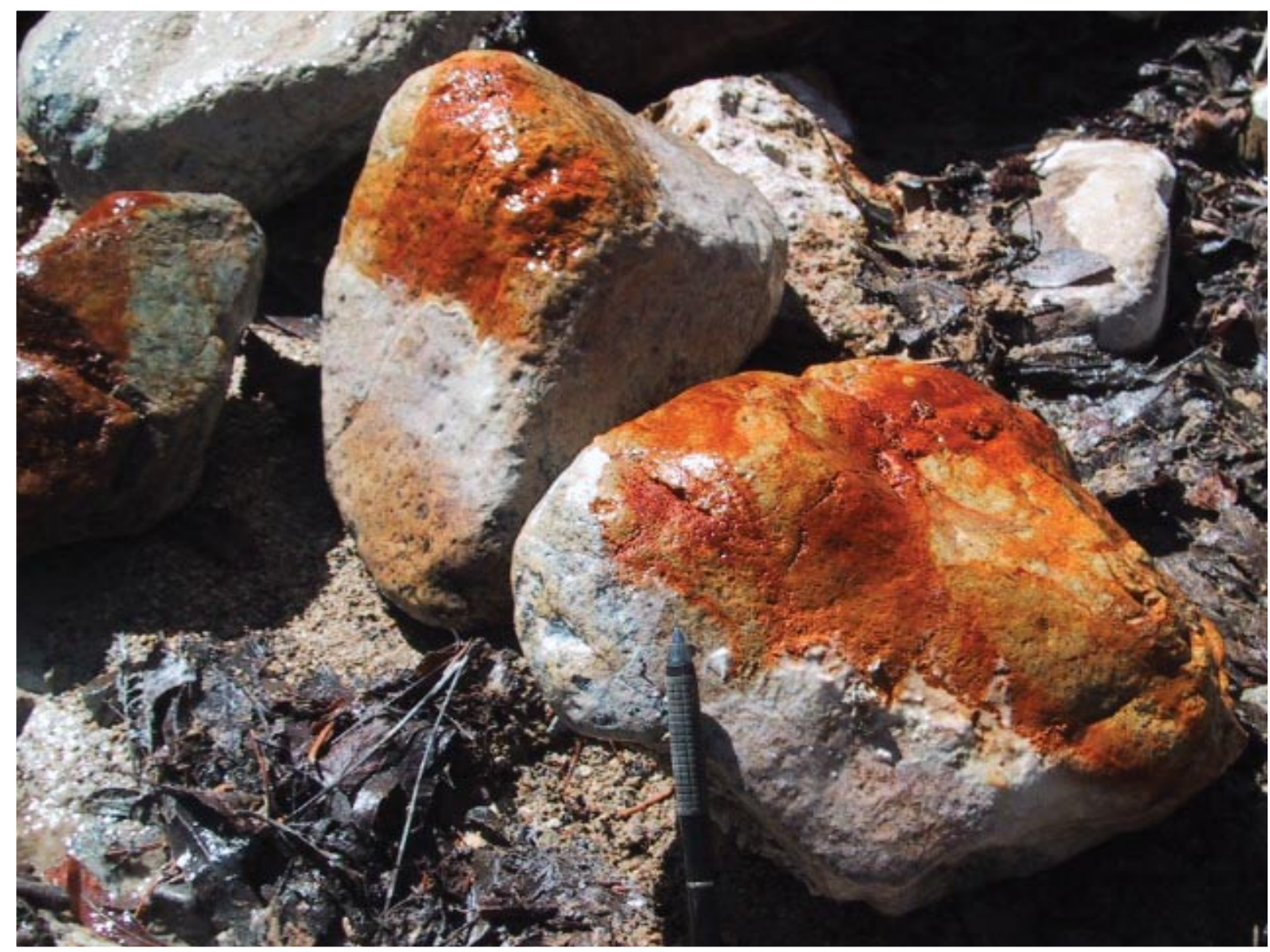

Prepared in cooperation with the

New Mexico Environment Department

Scientific Investigations Report 2006-5004 
Cover photo: Streambed cobbles from the Red River near Capulin Canyon, New Mexico. These cobbles have been turned over to show that iron oxyhydroxide precipitates (ochre color) form below the streambed and aluminum oxyhydroxide precipitates (white) form in the water column above the streambed. The difference occurs because the $\mathrm{pH}$ in the stream is greater than 7.0 and the $\mathrm{pH}$ in the streambed is less than 5.0. The visible chemical differences indicate that acidic ground water is entering the stream. 


\section{Questa baseline and pre-mining ground-water quality investigation. 23. Quantification of mass loading from mined and unmined areas along the Red River, New Mexico}

By Briant A. Kimball, D. Kirk Nordstrom, Robert L. Runkel, Kirk R. Vincent, and Phillip L. Verplanck

Scientific Investigations Report 2006-5004

Prepared in cooperation with the

New Mexico Environment Department 


\section{U.S. Department of the Interior \\ Gale E. Norton, Secretary}

\section{U.S. Geological Survey \\ P. Patrick Leahy, Acting Director}

Salt Lake City, Utah, 2006

For additional information write to:

U.S. Geological Survey

Director, USGS Utah Water Science Center

2329 W. Orton Circle

Salt Lake City, UT 84119-2047

Email: GS-W-UTpublic-info@usgs.gov

URL: http://ut.water.usgs.gov/

For more information about the USGS and its products:

Telephone: 1-888-ASK-USGS

World Wide Web: http://www.usgs.gov/

Any use of trade, firm, or product names is for descriptive purposes only and does not imply endorsement by the U.S. Government

Although this report is in the public domain, permission must be secured from the individual copyright owners to reproduce any copyrighted materials contained within this report.

Suggested citation:

Kimball, B.A., Nordstrom, D.K., Runkel, R.L., Vincent, K.R., and Verplanck, P.L., 2006, Questa baseline and premining ground-water quality investigation. 23. Quantification of mass loading from mined and unmined areas along the Red River, New Mexico: U.S. Geological Survey Scientific Investigations Report 2006$5004,45 \mathrm{p}$.

Scientific Investigations Report 2006-5004 


\section{Contents}

Abstract

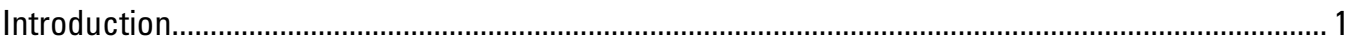

Physical Setting, General Geology and Hydrology, and Mining History.................................... 1

Geographic and Physiographic Features ................................................................. 1

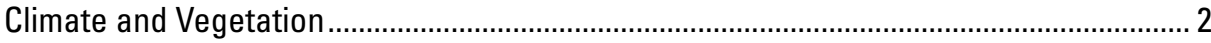

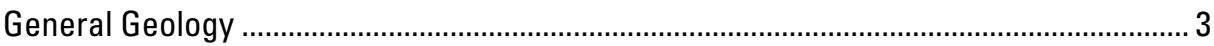

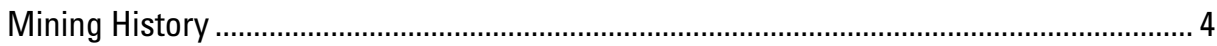

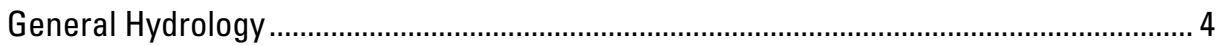

Surface Water ...................................................................................................... 4

Ground Water and Aqueous Geochemistry .............................................................. 5

Methods for Mass-Loading Analysis ..................................................................................... 5

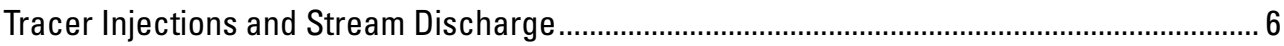

Synoptic Sampling and Analytical Methods ...................................................................... 7

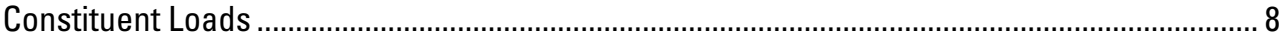

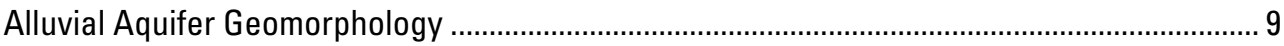

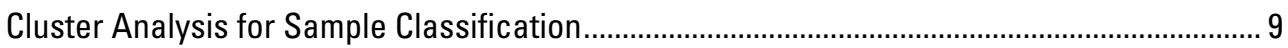

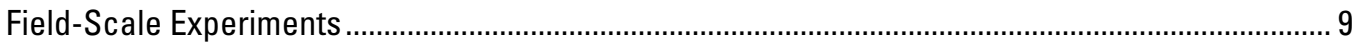

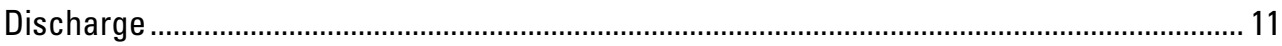

Chemical Variation of Synoptic Samples ............................................................................ 13

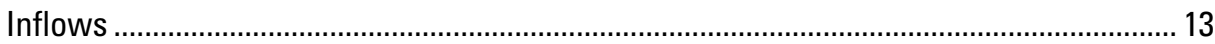

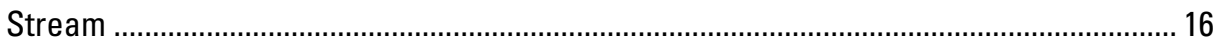

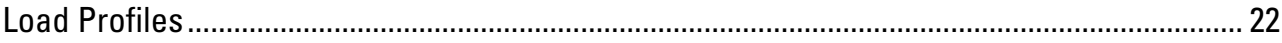

Load in 2001 versus 2002

Principal Locations of Mass Loading ................................................................................ 23

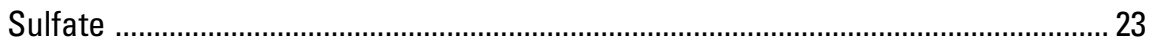

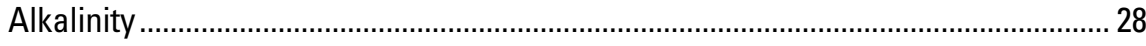

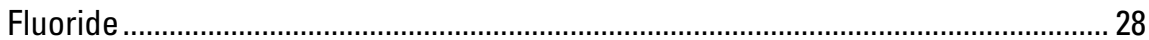

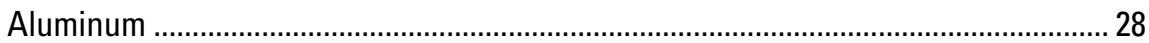

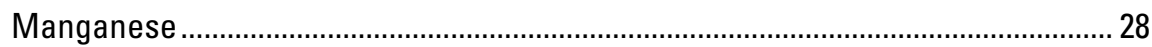

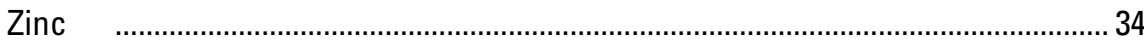

Implications for Mined versus Unmined Sections ................................................................ 34

Summary and Conclusions......................................................................................................... 34

References Cited

Appendix 


\section{Figures}

Figure 1. Location and topographic map of the study area, Red River, New Mexico, indicating reaches for tracer-injection studies and principal hydrothermal scars and intrusions ....... 2

Figure 2. Variation of bromide and sulfate concentration with time during the lower and middle injection periods, Red River, New Mexico.

Figure 3. Variation of bromide concentration and calculated discharge with distance along the study reach, Red River, New Mexico.

Figure 4. Variation of $(\mathrm{A}) \mathrm{pH}$ and $(\mathrm{B})$ sulfate concentration with distance along the study reach, (C) manganese concentration with fluoride concentration, and (D) basemetal concentration with $\mathrm{pH}$ for inflow samples to the Red River, New Mexico.

Figure 5. Variation of concentrations of $(A)$ manganese with sulfate and $(B)$ cadmium with zinc for median concentrations of inflow groups defined by cluster analysis and selected alluvial wells

Figure 6. Variation of $(\mathrm{A}) \mathrm{pH}$ and concentrations of $(\mathrm{B})$ manganaese and $(\mathrm{C})$ sulfate with distance along the study reach, Red River, New Mexico.

Figure 7. Variation of cumulative instream load of (A) manganese and (B) sulfate with distance along the study reach for 2001 and 2002, Red River, New Mexico

Figure 8. Variation of (A) sulfate load with distance along the study reach and (B) change in sulfate load for individual sections along the Red River, New Mexico, August 2001

Figure 9. Comparison of mass ratios for selected solute pairs in water from La Bobita Camground well and the Hansen alluvial well, near the Red River, New Mexico 26

Figure 10. Relation of calculated inflow concentration and sampled alluvial well concentrations to median, minimum, and maximum inflow concentrations for (A) sulfate, (B) aluminum, and (C) manganese in sections along the Red River, New Mexico

Figure 11. Variation of $(A)$ alkalinity load with distance along the study reach and $(B)$ change in alkalinity load for individual sections along the Red River, New Mexico, August 2001 ...... 29

Figure 12. Variation of (A) fluoride load with distance along the study reach and (B) change in fluoride load for individual sections along the Red River, New Mexico, August 2001. ....... 30

Figure 13. Variation of $(A)$ aluminum load with distance along the study reach and $(B)$ change in aluminum load for individual sections along the Red River, New Mexico, August 2001..... 31

Figure 14. Variation of (A) manganese load with distance along the study reach and (B) change in manganese load for individual sections along the Red River, New Mexico, August 2001

Figure 15. Variation of (A) zinc load with distance along the study reach and (B) change in zinc load for individual sections along the Red River, New Mexico, August 2001

Figure 16. Silhouette values for (A) inflow clusters and (B) stream clusters. Values near zero indicate a sample in between clusters. 


\section{Tables}

Table 1. Downstream distance, source, cluster analysis group, description, sample identification, pH, and estimated discharge for synoptic samples, Red River, New Mexico...

Table 2. Summary statistics for inflow groups defined by cluster analysis, Red River, New Mexico

Table 3. Summary of statistics for stream groups defined by cluster analysis, Red River, New Mexico.

\section{Conversion Factors, Datums, and Abbreviated Water-Quality Units}

\begin{tabular}{lcl}
\hline \multicolumn{1}{c}{ Multiply } & By & \multicolumn{1}{c}{ To obtain } \\
\hline cubic meter per second $\left(\mathrm{m}^{3} / \mathrm{s}\right)$ & 70.07 & acre-foot per day (acre-ft/day) \\
kilogram per day $(\mathrm{kg} / \mathrm{day})$ & 2.205 & pound per day (lb/day) \\
kilometer $(\mathrm{km})$ & 0.6214 & mile $(\mathrm{mi})$ \\
liter per second $(\mathrm{L} / \mathrm{s})$ & 15.85 & gallon per minute $(\mathrm{gal} / \mathrm{min})$ \\
meter $(\mathrm{m})$ & 3.281 & foot $(\mathrm{ft})$ \\
micrometer $(\mu \mathrm{m})$ & 0.00003937 & inch $(\mathrm{in})$. \\
milligram per second $(\mathrm{mg} / \mathrm{s})$ & 0.1905 & pound avoirdupois per day (lb/day) \\
milliliter $(\mathrm{mL})$ & 0.00382 & ounce, fluid (fl. oz) \\
square kilometer $\left(\mathrm{km}^{2}\right)$ & 247.1 & acre \\
\hline
\end{tabular}

Temperature in degrees Celsius $\left({ }^{\circ} \mathrm{C}\right)$ may be converted to degrees Fahrenheit $\left({ }^{\circ} \mathrm{F}\right)$ as follows:

$$
{ }^{\circ} \mathrm{F}=\left(1.8 \times{ }^{\circ} \mathrm{C}\right)+32 \text {. }
$$

Horizontal coordinate information is referenced to the North American Datum of 1983 (NAD 83) and vertical coordinate information is referenced to the North American Vertical Datum of 1929 (NAVD 29).

Chemical concentration and water temperature are reported only in metric units. Chemical concentration is reported in milligrams per liter (mg/L), micrograms per liter $(\mu \mathrm{g} / \mathrm{L})$, or millimoles per liter $(\mathrm{mM} / \mathrm{L})$. Milligrams per liter is a unit expressing the mass of solute per unit volume (liter) of water. For concentrations less than 7,000 milligrams per liter, the numerical value is about the same as for concentrations in parts per million. Specific conductance is reported in microsiemens per centimeter at 25 degrees Celsius $(\mu \mathrm{S} / \mathrm{cm})$. 



\title{
Questa baseline and pre-mining ground-water quality investigation. 23. Quantification of mass loading from mined and unmined areas along the Red River, New Mexico
}

\author{
By Briant A. Kimball, D. Kirk Nordstrom, Robert L. Runkel, Kirk R. Vincent, and Phillip L. Verplanck
}

\section{Abstract}

Along the course of the Red River, between the town of Red River, New Mexico, and the U.S. Geological Survey streamflow-gaging station near Questa, New Mexico, there are several catchments that contain hydrothermally altered bedrock. Some of these alteration zones have been mined and others have not, presenting an opportunity to evaluate differences that may exist in the mass loading of metals from mined and unmined sections. Such differences may help to define pre-mining conditions. Spatially detailed chemical sampling at stream and inflow sites occurred during low-flow conditions in 2001 and 2002, and during the synoptic sampling, stream discharge was calculated by tracer dilution. Discharge from most catchments, particularly those with alteration scars, occurred as ground water in large debris fans, which generally traveled downstream in an alluvial aquifer until geomorphic constraints caused it to discharge at several locations along the study reach. Locations of discharge zones were indicated by the occurrence of numerous inflows as seeps and springs. Inflows were classified into four groups, based on differences in chemical character, which ranged from near-neutral water showing no influence of mining or alteration weathering to acidic water with high concentrations of metals and sulfate. Acidic, metal-rich inflows occurred from mined and unmined areas, but the most-acidic inflow water that had the highest concentrations of metals and sulfate only occurred downstream from the mine. Locations of ground-water inflow also corresponded to substantial changes in stream chemistry and mass loading of metals and sulfate. The greatest loading occurred in the Cabin Springs, Thunder Bridge, and Capulin Canyon sections, which all occur downstream from the mine. A distinct chemical character and substantially greater loading in water downstream from the mine suggest that there could be impacts from mining that can be distinguished from the water draining from unmined areas.

\section{Introduction}

The Red River, in New Mexico, flows from Wheeler Peak in its headwaters to the Rio Grande River near Questa, New Mexico. Downstream from the town of Red River, the river drains several catchments that have been hydrothermally altered by waters associated with the emplacement of porphyry molybdenum deposits (fig. 1). The most economic of these deposits has been mined in the Questa Molybdenum mine since about 1920 (Schilling, 1956; 1990). To close the mine, ground-water quality standards must be met or else it must be shown that pre-mining conditions exceeded those standards. Because Federal and State regulators commonly need to understand pre-mining conditions, the presence of both mined and unmined alteration scars along the Red River presents an opportunity to evaluate differences in chemical signatures and mass loading that may be a result of mining. This study uses detailed chemical and mass-loading profiles from field-scale experimental studies to quantify and distinguish the loading contributions from the mined and unmined sections along the study reach to find differences in their chemical and loading signatures. The stream integrates both surface- and ground-water inflows, and this approach tests whether the sampled inflows along the study reach are sufficient to account for the observed changes in the stream, including contributions to stream loading that can come from the alluvial aquifer that has been shown to contain water with high metal and sulfate concentrations (Vail Engineering, 2000). Other reports in this series also have addressed issues of ground-water quality (LoVetere and others, 2004; Naus and others, 2005; Cheryl Naus, U.S. Geological Survey, written commun., 2005), to allow the comparison of sampled inflow chemistry to the ground-water chemistry.

\section{Physical Setting, General Geology and Hydrology, and Mining History}

\section{Geographic and Physiographic Features}

The study area is located in Taos County in the Taos Range of the Sangre de Cristo Mountains of north-central New Mexico (fig. 1). The Red River drainage basin is a tributary to the Rio Grande River within Carson National Forest. The area is a rugged and altered terrain with steep slopes and V-shaped valleys (fig. 1). The study reach of the Red River is in the Red River Valley between the Questa Ranger station at 2,280 m elevation at the west end and the town of Red River at 2,646 m 


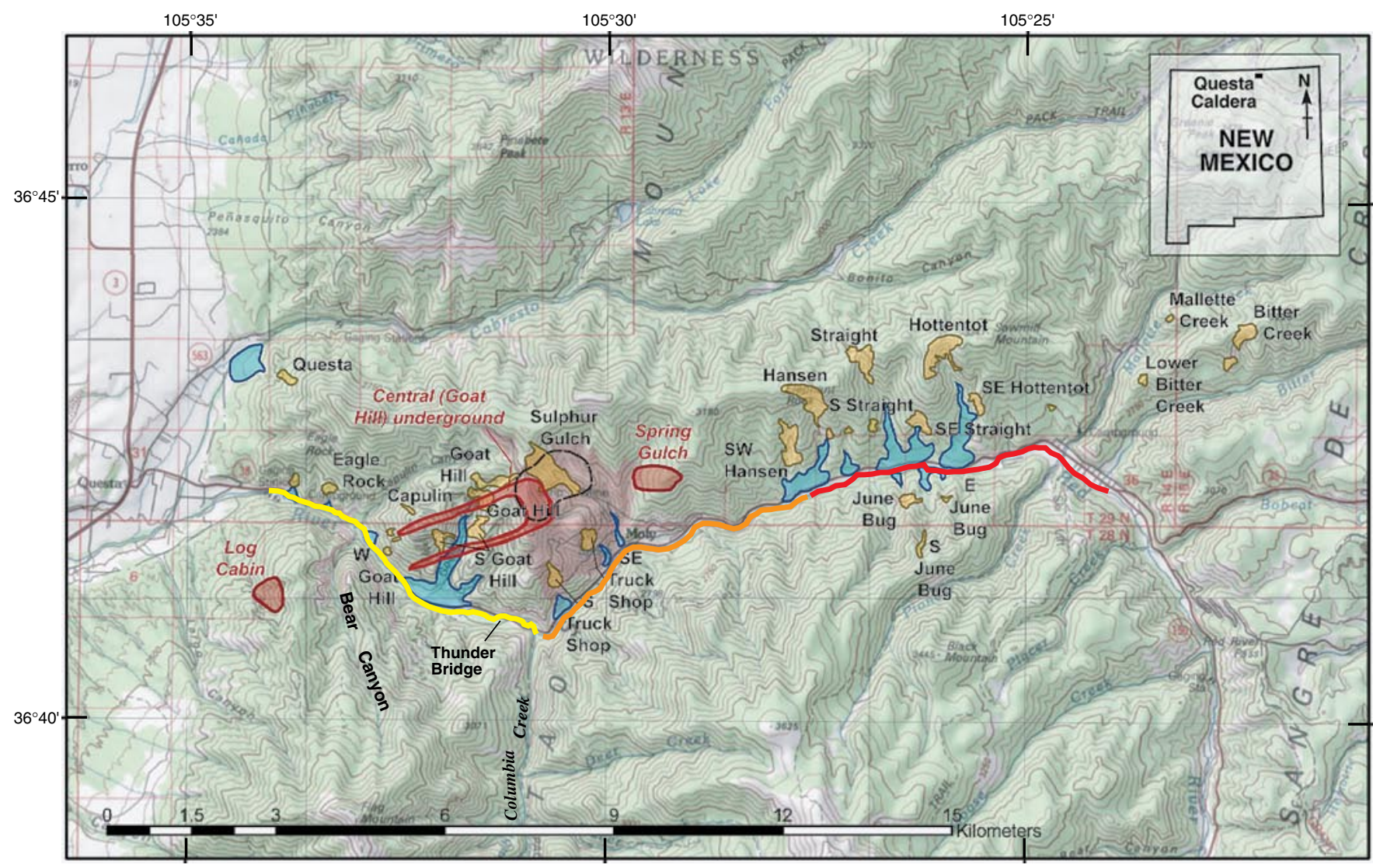

Figure 1. Location and topographic map of the study area, Red River, New Mexico, indicating reaches for tracer-injection studies and principal hydrothermal scars and intrusions. Features include lower injection reach (yellow line), middle injection reach (orange line), upper injection reach (red line), alteration scars (yellow areas), debris fans (blue areas), known ore bodies (red areas), the mine site (pink area), and the open pit (black dashed line). Topography from U.S. Geological Survey, 1:100,000 Taos $30 \times 60$ quadrangle.

elevation at the east end (fig. 1). The canyon walls of the Red River Valley climb rapidly from 2,400 $\mathrm{m}$ to more than 3,000 $\mathrm{m}$ at the ridge crest on both the north and south sides of the river. Some peaks reach nearly $3,500 \mathrm{~m}$. The $600 \mathrm{~m}$ difference in elevation between the Red River and the adjacent ridge crest can occur over a horizontal distance of less than $2,000 \mathrm{~m}$.

The Molycorp, Inc. Questa Molybdenum mine, referred to as the mine site, is located on the north side of State Highway No. 38 and the Red River $13 \mathrm{~km}$ east of the mountain front and mouth of the Red River canyon. The mine site is approximately $16 \mathrm{~km}^{2}$ and encompasses three main tributary valleys to the Red River: Capulin Canyon, Goat Hill Gulch, and Sulphur Gulch, from west to east respectively (fig. 1).

Mining activities produced extensive underground workings and an open pit of approximately $0.65 \mathrm{~km}^{2}$ near or in Sulphur Gulch. Waste-rock piles cover steep slopes on the north side of the Red River between Capulin Canyon and Spring Gulch (a tributary valley of Sulphur Gulch). Hydrothermally altered and extensively fractured and faulted areas of bedrock are present in Capulin, Goat Hill, Sulphur, Hansen, Straight, June Bug, Hottentot and Bitter Creek drainages (fig. 1). The latter five drainages are examples of unmined drainages with the exception of minor prospects in Bitter Creek. Weathering of extensively altered rock along fracture networks and fault zones has resulted in steep, highly erosive, sparsely vegetated "alteration scars" that are clearly visible from the ground and in aerial photographs (Meyer and Leonardson, 1990). Where there has been no mining these scar areas also are important natural sources of trace-metal and acid loading to surface and ground waters.

\section{Climate and Vegetation}

The Red River Valley is located within a semi-arid desert that receives precipitation throughout the year and sustains moderate biodiversity. According to the Western Regional Climate Center (written commun., 2005), between 1915 and 2002 , the average annual temperature was $4^{\circ} \mathrm{C}$, the precipitation and snowfall were $52 \mathrm{~cm}$ and $370 \mathrm{~cm}$, respectively, and the daily temperatures generally fluctuated by $18^{\circ} \mathrm{C}$ throughout the year.

Climate and vegetation vary greatly within short distances because of differences in topography, weather, bedrock, and sediment composition. Orographic effects of mountainous topography lead to precipitation on the windward slopes and localized storms within tributary valleys. Major precipitation 
events include summer thunderstorms and winter-spring snowstorms. Thunderstorms are responsible for mass wasting in hydrothermally altered scar areas, producing debris flows that potentially impact vegetation, alluvial aquifers, and the Red River. Winter snowpack contributes to ground-water recharge through snowmelt infiltration and runoff.

Prevalent vegetation in the Red River Valley is representative of the following altitude zones: piñon-juniper woodland (1,800-2,300 m), mixed conifer woodland (2,300-2,740 m), and spruce-fir woodland (2,740-3,660 m; Knight, 1990). Willows, cottonwoods, shrubs, perennial grasses, and flowering vegetation are common near the banks of the Red River. Extending from the river are widely spaced piñon pines and junipers. Gains in altitude give rise to an abundance of ponderosa pines and lumber pines, whereas Douglas fir and white fir can be found at higher altitudes. This typical mountain community, although diverse, is dominated by ponderosa pines (L. Gough, oral communication, 2003).

\section{General Geology}

The geochemical interaction of water with soil, colluvium, alluvium, and fractured bedrock produces the composition of surface and ground waters that are the overall focus of the baseline and pre-mining ground-water quality investigation. Hence, the geology is a fundamental component to understanding the hydrology and ground-water chemistry. This section briefly summarizes the general geologic framework from several studies (Lipman, 1981; Meyer and Leonardson, 1990; Rehrig, 1969; Schilling, 1956), in addition to observations made by the USGS scientists currently working at the site.

The Taos Range is composed of Precambrian metamorphic rocks and granitic intrusive rocks overlain and intruded by Tertiary volcanic and plutonic rocks (Lipman and Reed, 1989). The volcanics are primarily intermediate to felsic composition (andesites to rhyolites), and are intruded by Late Oligocene and Early Miocene quartz monzonites and granites that provided the source of the hydrothermal fluids and molybdenite mineralization. The hydrothermally altered volcanics often contain pyrite mineralization (generally 1-3 percent). The Red River Valley is located along the southern edge of the Questa volcanic caldera and contains complex structural features and extensive hydrothermal alteration associated with the evolution of the Rio Grande rift (fig. 1). The mineral deposits in the Red River Valley are considered Climax-type deposits that are associated with silica- and fluorine-rich rhyolite porphyry and granitic intrusives. The three principal alteration zones include highly altered quartz-sericite-pyrite (QSP), less-altered argillic (dominantly kaolinite) zones, and mildly altered propylitic zones (containing calcite mineralization). QSP alteration, as the name implies, produces a mixture of quartz, pyrite (up to 10 percent), and fine-grained mica (sericite) or illite. Chlorite, epidote, albite, and calcite typically are present in the propylitic assemblages. Ore deposits contain quartz, molybdenite, pyrite, fluorite, calcite, manganif- erous calcite, dolomite, and rhodochrosite. Lesser amounts of galena, sphalerite, chalcopyrite, magnetite, and hematite also are present. The hydrothermal alteration related to mineralization overprints an older, regional propylitic alteration. In these areas, rocks can contain a mixture of quartz, pyrite, and illite clays replacing feldspars, chlorite, carbonates, and epidote. Abundant minerals in waste rock produced by mining activities include chlorite, gypsum, illite, illite-smectite, jarosite, kaolinite, and muscovite (Gale and Thompson, 2001).

Andesite volcanic and volcaniclastic rocks are present in most scar-area bedrock outcrops and are the dominant bedrock units in the Straight Creek, South and Southeast Straight Creek, South Goat Hill, Sulphur Gulch, and Southwest Hansen scars (Ludington and others, 2004 and fig. 1). Amalia Tuff, a mildly alkaline, rhyolitic tuff, is the dominant rock type in the Goat Hill and Hansen scars, and quartz latite porphyry is the main rock type in the June Bug and Southeast Hottentot scars (fig. 1). Rhyolite porphyry is the main rock type in the Hottentot scar, and quartz latite and rhyolite porphyries form the hill slopes of many scars. Rhyolite porphyry and tuff do not seem to have been substantially affected by propylitization. Advanced argillic alteration was identified in the Hansen and Hottentot scars and in areas southwest of the Molycorp open pit. Propylitized andesite bedrock is present in several drainages that typically do not contain alteration scars.

After eruption of the Amalia Tuff and the Rio Grande rift began to form 26 million years ago, the landscape of the study area consisted of a broad, low relief plateau (P. Lipman, written communication, 2005). Rifting has caused as much as $7 \mathrm{~km}$ of structural relief across the Sangre de Cristo fault system - the eastern structural boundary of the rift and the western boundary of the Sangre de Cristo mountain block (Grauch and Keller, 2004; Kluth and Schaftenaar, 1994). Tectonically driven uplift caused the Red River to incise into the Taos Range resulting in the development of the today's rugged terrain (Kirk Vincent, U.S. Geological Survey, written commun., 2005). However, prior to a million years ago the Red River was essentially the headwater of the Rio Grande and it flowed near the level of the top of the sediments within the rift basin (Wells and others, 1987). About 700 to 600 thousand years ago the San Luis basin was captured by the Rio Grande, dramatically increasing discharges, increased incision in the Rio and tributary watersheds, and relegated the Red River to the status of one of those tributaries (Wells and others, 1987). Although thin Pleistocene alpine glaciers formed in the highest peaks of the Sangre de Cristo mountains, they likely had little influence on the form of the Red River Valley.

During the late Holocene, forested hillslopes eroded at about $0.04 \mathrm{~mm} / \mathrm{yr}$ as compared to the then-exposed alteration scars which eroded at about $3.0 \mathrm{~mm} / \mathrm{yr}$ (Kirk Vincent, U.S. Geological Survey, written commun., 2005). This extremely rapid erosion rate caused tributary watersheds containing alteration scars to deliver more sediment to the Red River than it could transport away, thus developing large debris fans to interfinger with alluvial sediments within the valley. These hydrothermally and structurally controlled facies relations 
have resulted in significant heterogeneities within the generally high permeability Red River Valley alluvial aquifer because the fan deposits have several orders of magnitude lower permeability than the alluvial deposits.

Tectonic deformation, in addition to and accompanying igneous and exhumation processes from Precambrian through Holocene times, has produced a highly complex array of folds, fault zones, fractures, and veins. Since the inception of the caldera in the Oligocene, the region around the Red River Valley has been in a tensional stress regime which has ultimately produced the ancient and modern Rio Grande rift as discussed above (Meyer and Foland, 1991). Generally north-northwest to north-northeast striking extensional fault zones, that have been progressively reactivated during the coupled development of the caldera, ore mineral system, and the eastern rift flank have accommodated approximately 200-percent extensional strain focused in the caldera (Meyer and Foland, 1991). These fault zones show a wide variety of internal deformation and structures, degree of mineralization, and dip. Numerous fracture networks, joints, and veins pervasively penetrate the entire study area. Collectively these brittle structures form the permeability structure, in otherwise generally low permeability crystalline rock, in which the modern geochemical and ground-water flow system exists.

Bedrock at the surface and buried under alluvial, colluvial, and anthropogenic deposits shows a variable and complex zone of weathering. Samples collected from a bedrock weathering profile in the Straight Creek scar were studied in detail to characterize the mineralogic variations in a weathered profile (Ludington and others, 2004). Relatively unweathered bedrock exposed in the creek bottom is propylitized andesite with a QSP overprint. Depending on location within the weathering profile, altered rocks contain variable amounts of quartz, illite, chlorite, and plagioclase feldspar, with smaller amounts of pyrite, gypsum, rutile, jarosite, and goethite (Livo and Clark, 2002; Ludington and others, 2004). Calcite, goethite, and sericite are widely distributed in the Red River valley rocks and soils as revealed by Airborne Visible/InfraRed Imaging Spectrometer (Livo and Clark, 2002). Calcite is an important mineral in the Red River Valley because its dissolution effectively neutralizes the acid inflows so that $\mathrm{pH}$ values in the Red River tend to be alkaline (pH 7-8). Gypsum is commonly found throughout the Red River valley and forms as a secondary product of acid-sulfate weathering when pyrite oxidizes and reacts with calcite. Because gypsum is soluble in water, calcium and sulfate are the major ions for most surface and ground waters in the Red River Valley.

The major minerals in rock samples collected during mineral exploration and mining are biotite, calcite, chalcopyrite, fluorite, galena, molybdenite, pyrite, quartz, rhodochrosite, and sphalerite. Mining activities produced roughly 328 million tons of rock overburden in Capulin Canyon, along the north slope of the Red River, and in Goat Hill, Sulphur and Spring Gulches (URS, 2001). The abundant minerals in waste rock samples include chlorite, gypsum, illite, illite-smectite, jarosite, kaolinite, and muscovite (Gale and Thompson, 2001).

\section{Mining History}

Prior to 1916, prospectors discovered outcrops of rich yellow weathered rock that looked like sulfur (hence the name, Sulphur Gulch) and a greasy mineral that looked like graphite (fig. 1). The graphitic mineral was identified as molybdenite in 1916 and the yellow mineral was ferrimolybdite, the oxidized product derived from the weathering of molybdenite (Schilling, 1956). By 1920 the Molybdenum Corporation of America had acquired the property to mine the deposit and the company subsequently shortened its name to Molycorp, Inc. A mill and flotation plant was set up by 1923 for production and small-scale underground mining of high-grade veins (averaging 4\% with a maximum of 35\%) continued until 1958 . During the 1950s, exploration had identified a large low-grade deposit (about 0.3 percent) below the high-grade deposit and the decision was made to extract this ore by open-pit methods (Carpenter, 1968). Extraction of open-pit ore began in 1965 and tailings were transported by a 9-mile long pipeline to a tailings facility in the Rio Grande Valley just west of Questa. Peak production occurred in 1976 with 11.5 million pounds per year. In 1977 Molycorp, Inc. became a wholly owned subsidiary of Union Oil Company of California.

Open-pit mining ceased in 1983 and underground mining restarted. Waste rock was no longer dumped onto piles at the mine site, but the amount of tailings increased. Low market values for molybdenum have periodically caused the mine to shut down (1986-89 and 1992-1995). Active mining continues at Molycorp's Questa mine in response to market demand. Further history and related information on the Questa Molycorp mine is available from Molycorp, Inc. www.molycorp. com) and from the U.S. Environmental Protection Agency (U.S. Environmental Protection Agency, 2005).

\section{General Hydrology}

\section{Surface Water}

The Red River originates at an altitude of approximately 3,658 m near Wheeler Peak, the highest peak in New Mexico $(4,011 \mathrm{~m})$, and flows roughly $55 \mathrm{~km}$ to its confluence with the Rio Grande River at an altitude of 2,012 m. Total basin drainage area is $492 \mathrm{~km}^{2}$ and the drainage area upstream from the Questa Ranger Station gaging station (at the mouth of the Red River Canyon) is $293 \mathrm{~km}^{2}$ (fig. 1). Peak streamflow typically occurs from late May to mid-June, with snowmeltrelated flows beginning in late March and increasing through mid-April. Summer thunderstorms are prevalent in July and August. Between 1930 and 2001, the mean annual discharge of the Red River at the Questa Ranger Station gage has ranged from 0.36 to $2.92 \mathrm{~m}^{3} / \mathrm{s}$, while the average daily discharge ranged from 0.07 to $21.24 \mathrm{~m}^{3} / \mathrm{s}$ with an average of $1.33 \mathrm{~m}^{3} / \mathrm{s}$ (U.S. Geological Survey, 2005).

The main drainages in the vicinity of the mine site are Capulin Canyon, Goat Hill Gulch, and Sulphur Gulch on the north side of the Red River (fig. 1). Upstream from the 
mine site, Southwest Hansen, Hansen, Straight, Hottentot, and Bitter Creeks drain scar areas whereas Mallette Creek drains a non-scar area on the north side of the Red River. Bear Canyon, Columbine, Pioneer, and Placer Creeks drain largely unmineralized land on the south side of the river (fig. 1). Bear Canyon and upper Pioneer Creeks also contain some mineralization. Downstream from the mine site and in the Rio Grande Rift Valley, the Red River joins with Cabresto Creek, entering from the north side of the Red River, before it discharges to the Rio Grande.

Springs and shallow alluvial ground water discharge to the Red River rendering it a gaining stream over much of its length (Smolka and Tague, 1989). Between the town of Red River and the gaging station near Questa, there are many ephemeral seeps and springs along the banks of the Red River and also intermittent seeps and springs in tributary drainages on the north side of the river (South Pass Resources, Inc., 1995; Steffen, Robertson, and Kirsten, 1995; Robertson GeoConsultants, 2001). Most seeps and springs are acidic ( $\mathrm{pH}$ 2-4) with high conductance, dissolved solids, and metal concentrations. Aluminum hydroxide often precipitates from springs down-gradient from scar and mined areas on the north side of the Red River, affecting the color and turbidity of the river. These and other seeps and springs were sampled in this study.

\section{Ground Water and Aqueous Geochemistry}

Aquifer units in the Red River Valley are highly varied. Waste-rock piles and scars with associated debris fans are geochemically reactive, have high porosity, and relatively high permeability. Alluvial aquifers are restricted in aerial extent and have variable compositions. Hillslope soils are thin and composed of materials eroded from adjacent up-gradient slopes. Debris fans are composed of sediments rapidly shed from their respective watersheds. Where the tributary watersheds contain "alteration scars" the debris fans are large and active, and contain both coarse and fine-grained, largely unsorted clay-rich, debris-flow sediments, making them heterogeneities in the alluvium as discussed above.

The chemistry of these sediments reflects the chemistry of their source terrains. The rapidly eroding and altered erosion scars have source materials that can generate low $\mathrm{pH}$, trace-metal-rich ground waters. Sediments deposited by the Red River, in contrast, generally consist of well-washed, rounded sands, gravels, and cobbles and are composed of a mix of lithologies found in the entire Red River basin, including carbonates from the uppermost reaches. The largest debris fans caused the Red River alluvium to aggrade behind the fans during the Quaternary. Thus, ground water flowing in the shallow alluvial aquifer passes alternately through Red River alluvium and debris fans and may emerge when a relatively low permeability fan is encountered. Both the Red River alluvium and debris fans act as a complex aquifer unit that is less than several hundred meters wide and less than $100 \mathrm{~m}$ thick.
Alluvial ground water is a calcium-sulfate water type with magnesium, the second most abundant cation. Ground water downgradient from the waste-rock piles and scars has acidic $\mathrm{pH}$ values and elevated metal concentrations compared to ground water upgradient from these altered areas.

The bedrock aquifer constitutes the largest volume of aquifer in the study area but probably contains only relatively small amounts of ground water below the weathered zone because of inferred low porosity and low permeability largely controlled by fracture networks. Bedrock ground waters are also calcium-sulfate type but generally of neutral $\mathrm{pH}$. Most wells developed in the Red River Valley were installed to monitor water quality downgradient from mining operations (waste-rock and tailings piles) and/or scar areas. Wells installed in the Straight Creek drainage (fig. 1) during this study were developed for the purpose of measuring water levels and collecting water-chemistry data for a range of environments in the Red River Valley, similar to the mine environment, and to interpret the water-rock interactions under non-mining baseline conditions as a reference for pre-mining water-rock interactions for the mine site.

Hydrothermal alteration produced substantial changes in mineralogy over relatively short distances, a common feature of hydrothermally altered terrains. Hence, both the mineralogy and the resultant water chemistry can change substantially on a small spatial scale. Such hydrogeochemical environments are described as highly heterogeneous, making the estimation of pre-mining ground-water chemistry a highly variable function of changing lithology rather than single fixed concentrations for an area the size of the mine site.

A companion study to this report (Kirk Vincent, U.S. Geological Survey, written commun., 2005) evaluated the geomorphology and ground-water flow of the alluvial aquifer to help constrain the geochemical interpretations provided here. Loading of sulfate to the Red River is discussed in a report by Vail Engineering (Vail Engineering, 2000), which points out the influence of ground-water discharge from the alluvial aquifer on sulfate loads in the Red River. The work detailed here illustrates important similarities with the Vail Engineering (2000) report. However, the additional spatial detail and analysis of more chemical constituents adds important resolution to and allows additional interpretation of the sources of solutes in the Red River and the role of drainage from alteration zones.

\section{Methods for Mass-Loading Analysis}

The ability to quantify and distinguish loads entering the Red River depends on the ability to quantify mass loading. The mass-loading approach used here addresses the problem of solute source determination (Kimball and others, 2002). This study is based on two well-established techniques: the tracer-dilution method (Kilpatrick and Cobb, 1985) and synoptic sampling (Bencala and McKnight, 1987). The tracer-dilution method provides estimates of stream discharge 
that are used in turn to quantify the amount of water entering the stream in a given stream segment through tributary and ground-water inflow. Synoptic sampling of stream and inflow chemistry provides a spatially detailed "snapshot" of stream-water quality and the inflows that influence changes in the stream. When used together, these techniques provide a description of a watershed that includes both discharge and concentration that may then be used to determine mass loading of chemical constituents associated with various sources of surface and ground water. Hence, it is possible to compare chemical signatures and mass-loading contributions between mined and unmined sections.

The studies described below were undertaken during low-flow conditions in August 2001 and March 2002. Application of the method to low-flow conditions provides a focus on metal sources that enter the stream on a continuous basis, but the values of loading from the low-flow study might not be representative of a mean annual value needed for remediation engineering. Profiles obtained from low-flow studies, however, will be a good indication of the pattern of mass loading throughout the year.

A critical step in this approach was to walk the entire study reach and identify visible inflows and areas of likely ground-water inflow. Stream-sampling sites are located upstream and downstream of these visible inflows and in locations that may bracket areas of potential ground-water inflow. These areas can be identified during the stream reconnaissance by considering changes in vegetation, geomorphologic controls, and geologic structure. Distance along the study reach is measured from the tracer-injection site, which is assigned a distance of $0 \mathrm{~m}$. This downstream metric provides an ordinate for the study and for computer simulation studies (Kimball and others, 2003; Runkel and Kimball, 2002). Each stream site represents the downstream end of a stream segment, and stream segments divide the watershed into increments to account for instream and inflow loads. At this level of spatial detail, changes in stream chemistry and discharge between stream sampling sites reflect a net metal load for specific segments. Specific sources that are responsible for the loading that occurs within particular stream segments, however, cannot always be identified at this stream-reach scale.

\section{Tracer Injections and Stream Discharge}

Quantifying discharge in mountain streams by the traditional velocity-area method (Rantz, 1982) can be compromised due to the roughness of the streambed and the variability caused by pools and riffles (Jarrett, 1992). Furthermore, a substantial percentage of stream water may be flowing through porous areas of the streambed that comprise the hyporheic zone (Zellweger and others, 1989). Measurement of discharge using the velocity-area method does not account for flow through the hyporheic zone, and discharge estimates based on the velocity-area method may result in an underestimate of metal loads (Zellweger and others, 1989). Another limitation of the velocity-area method for the characterization of metal loads is the time limit it may place on the number of sites that can be sampled in 1 day. In the studies described below, numerous (often about 60) instream samples were collected during a single day to characterize stream and inflow chemistry within the hydrologic context of the tracer injection. Velocity-area discharge measurements performed in conjunction with sample collection at such a large number of sites would be difficult, if not impossible.

An alternative means of estimating discharge used in this study is the tracer-dilution method (Kilpatrick and Cobb, 1985). To apply the tracer-dilution method, an inert tracer is continuously injected into the stream at a constant rate and concentration. A key factor is the ability to maintain a constant rate during the continuous tracer injection. During this study, tracer injections were controlled with precision metering pumps linked to a data logger. Use of the data logger provides a means to maintain a constant injection rate as battery voltage decreases. Given sufficient time, all portions of the stream including side pools and the hyporheic zone will reach a steady tracer concentration (Broshears and others, 1993). Decreases in that steady concentration with distance downstream reflect the dilution of tracer by additional surface and ground water entering the channel. Consideration of this dilution allows for the calculation of discharge at each stream site. Application of the tracer-dilution method addresses both of the problems noted above: (1) the tracer enters porous areas of the streambed such that flow through the hyporheic zone is accounted for; and (2) collection of tracer samples when steady concentrations are achieved provides the ability to obtain discharge estimates at numerous locations.

Mass-balance equations are used to determine stream discharge, which is based on the observed dilution of the bromide tracer. Because of the circum-neutral $\mathrm{pH}$ values found in the Red River, sodium bromide was used in the individual studies described herein. The bromide tracer provided a large concentration contrast with background bromide, and also has little tendency to sorb to solid materials in the neutral $\mathrm{pH}$ range of these waters. In addition, spatial variability in background concentrations was low, such that background concentrations were nominally uniform. Given these conditions, stream discharge at any location downstream of the injection is given by:

$$
Q_{A}=\frac{Q_{I N J} C_{I N J}}{C_{A}-C_{b g}}
$$

where:

$Q_{A}$ is the stream discharge, in $\mathrm{L} / \mathrm{s}$,

$Q_{I N J}$ is the injection rate, in $\mathrm{L} / \mathrm{s}$,

$C_{I N J}$ is the injectate concentration, in $\mathrm{mg} / \mathrm{L}$,

$\mathrm{C}_{\mathrm{A}}$ is the tracer concentration at plateau, in $\mathrm{mg} / \mathrm{L}$, and

$C_{b g}$ is the naturally occurring background concentration, in $\mathrm{mg} / \mathrm{L}$. 
Alternatively, stream discharge may be calculated sequentially, given a known discharge at an upstream site:

where:

$$
Q_{B}=\frac{Q_{A}\left(C_{A}-C_{B G}\right)}{\left(C_{B}-C_{B G}\right)}
$$

$Q_{B}$ is the stream discharge at the downstream site, in L/s,

$Q_{A}$ is the stream discharge at the upstream, in $\mathrm{L} / \mathrm{s}$,

$C_{A}$ is the tracer concentration at the upstream site, in $\mathrm{mg} /$ $\mathrm{L}$,

$C_{B}$ is the tracer concentration at the downstream site, in $\mathrm{mg} / \mathrm{L}$, and

$C_{b g}$ is the naturally occurring background concentration, in $\mathrm{mg} / \mathrm{L}$.

Additional information on tracer-dilution is available in Kimball and others (2002). Previous studies document the transport, chemistry, and toxicity of inorganic tracers (Bencala and others, 1990; Broshears and others, 1993; Tate and others, 1995; Zellweger, 1994).

The tracer can be diluted in several ways. If there is no visible inflow or there are seeps or springs in a stream segment, the change in stream discharge comes from dispersed, subsurface inflow. If there is a tributary inflow, the change calculated by tracer-dilution includes both the surface-water tributary inflow and any dispersed, subsurface inflow that may be associated with the tributary or dispersed, subsurface inflows. Individual discharge measurements of tributary surface-water inflows were not made.

Discharge of an inflow is assigned the difference in discharge between the downstream and upstream stream sites:

$$
Q_{I}=\left(Q_{B}-Q_{A}\right)
$$

where:

$Q_{I}$ is theinflow discharge, in $\mathrm{L} / \mathrm{s}$,

$Q_{B}$ is the downstream discharge, in $\mathrm{L} / \mathrm{s}$, and

$Q_{A}$ is the upstream discharge, in L/s.

For more than one inflow sample in a single stream segment, the discharge assigned to the individual inflows is proportioned according to mass balance using the concentrations of a conservative constituent (often sulfate at high $\mathrm{pH}$ ) from the inflows and the change of constituent mass along the stream segment.

\section{Synoptic Sampling and Analytical Methods}

The spatial distribution of metal sources may be characterized by synoptic sampling. Under ideal conditions, samples at all of the sampling sites would be collected simultaneously, providing a description of stream-water quality at steady state. Personnel limitations generally preclude simultaneous sample collection, but the synoptic studies described below provide an approximate means of describing steady-state conditions. This approximation is achieved by collecting samples over a relatively short time (less than 8 hours) and by conducting the studies under low-flow conditions such that the effects of diurnal flow variation are minimized.

For each of the studies described below, stream and inflow samples were collected at predetermined sites, beginning at the downstream end of the study reach and ending upstream of the tracer-injection site. This downstream-toupstream sampling order was followed in order to avoid disturbing streambed materials. Inflow and stream sites that were considered well mixed were sampled using grab techniques. Sites that were not well mixed were sampled by equal width integration (Ward and Harr, 1990). Water temperature was measured onsite and water samples were transported to a central location where samples were divided into several 125$\mathrm{mL}$ bottles with different treatments at the central processing location: a raw (unfiltered) unacidified sample (RU), a raw acidified sample (RA), a filtered unacidified sample (FU), a filtered acidified sample (FA), and an ultrafiltered, acidified sample (UFA).

Specific conductance and $\mathrm{pH}$ were determined from the RU sample within hours of sample collection. Tangential-flow filtration was used with $0.45-\mu \mathrm{m}$ membranes (FU and FA samples) and 10,000-Dalton molecular weight membranes (UFA ultrafiltration sample). Metal concentrations for the RA, FA, and UFA treatments were determined by inductively coupled plasma-atomic emission spectrometry (Lichte and others, 1987). Anion concentrations were determined from FU samples using ion chromatography (Brinton and others, 1996; Kimball and others, 1999). Ferrous iron was determined colorimetrically from the UFA sample (Stookey, 1970; To and others, 1998). Fluoride was determined by ion-sensitive electrode (Barnard and Nordstrom, 1982). Total alkalinity was determined by titration from the FA sample (Barringer and Johnsson, 1989).

Use of two filtration techniques provides three different operationally defined concentrations for each metal. Metal concentration from the unfiltered sample (RA) is a measure of the total-recoverable concentration (dissolved + colloidal), and the ultrafiltrate concentration (UFA) is a measure of the dissolved metal concentration. Colloidal metal concentrations are defined here as the difference between the total-recoverable (RA) and the ultrafiltrate metal concentrations (UFA) for stream samples (Kimball and others, 1995). The 0.45- $\mu \mathrm{m}$ concentration (FA) is a measure of dissolved and colloidal concentrations that will pass through the $0.45-\mu \mathrm{m}$ filter. Aquatic standards for toxicity generally are based on $0.45-\mu \mathrm{m}$ filtration. 


\section{Constituent Loads}

Sampled instream load may be calculated for each stream sampling site along the study reach as:

where:

$$
M_{A}=C_{A} Q_{A}(0.0864)
$$

$M_{A}$ is the constituent load, or mass flux, at location $A$, in $\mathrm{kg} / \mathrm{day}$,

$C_{A}$ is the concentration of the selected constituent at location $A$, in $\mathrm{mg} / \mathrm{L}$,

$Q_{A}$ is the discharge at location $A$, in $\mathrm{L} / \mathrm{s}$, and

0.0864 is the conversion factor from $\mathrm{mg} / \mathrm{s}$ to $\mathrm{kg} / \mathrm{day}$.

Sampled instream load is calculated from the total-recoverable concentration of the constituent, but dissolved and colloidal loads can be calculated individually if both filtered and totalrecoverable samples are collected. The longitudinal profile of sampled instream load constitutes the basic data for the massloading approach.

For each stream segment, the change in load between a pair of stream sites accounts for the gain or loss of constituent load for that segment. The change in load for the segment starting at location $A$ and ending at location $B$ is:

where:

$$
M_{S}=\left(C_{B} Q_{B}-C_{A} Q_{A}\right)(0.0864)
$$

$M_{S}$ is the change in sampled instream load from location $A$ to $B$, in $\mathrm{kg} /$ day,

$C_{B}$ is the concentration of the selected constituent at location $B$, in $\mathrm{mg} / \mathrm{L}$,

$Q_{B}$ is the discharge at location $B$, in $\mathrm{L} / \mathrm{s}$, and

$C_{A}, Q_{A}, 0.0864$ are defined in equation 4 .

Gains in constituent load ( $M_{S}$ is greater than zero) imply that there is a source that contributes to the stream between the two stream sites. However, there could be instream processes that reduce the net gain; thus, the measured change may not indicate the total magnitude of the source. Instream load also can decrease within a stream segment ( $M_{S}$ is less than zero), meaning that there is a net loss of the constituent as a result of physical, chemical, or biological processes. A net loss does not preclude the presence of a source of loading for a particular stream segment, but it does preclude quantifying the magnitude of that source. Summing all the increases in load between sampling sites along the study reach (positive values of $M_{S}$ ) leads to the cumulative instream load. At the end of the study reach, the cumulative instream load is the best estimate of the total load added to the stream but is likely a minimum estimate because it only measures the net loading between sites and does not account for metal loads added to and then lost from the water column within individual stream segments.

For those segments that include one or more sampled inflows, it is possible to evaluate how well the sampled inflow accounts for the instream changes. If stream sites $A$ and $B$ bracket one inflow sample, location $I$ :

where:

$$
M_{I}=C_{I}\left(Q_{B}-Q_{A}\right)(0.0864)
$$

$M_{I}$ is the sampled inflow load between location $A$ and $B$, in $\mathrm{kg} / \mathrm{day}$,

$C_{I}$ is the concentration of the selected constituent at inflow location $I$, in $\mathrm{mg} / \mathrm{L}$, and

\section{$Q_{A}, Q_{B}, 0.0864$ are defined in equations 4 and 5 .}

Summing the sampled inflow loads along the study reach produces a longitudinal profile of the cumulative inflow load that can be compared to the cumulative instream load. Commonly in streams affected by mine drainage, the cumulative instream load is greater than cumulative inflow load. This result can indicate important areas of unsampled inflow, defined as:

where:

$$
M_{U}=M_{S}-M_{I}
$$

$M_{U}$ is unsampled inflow load between locations $A$ and $B$, in $\mathrm{kg} / \mathrm{day}$, and

$M_{S}, M_{I}$ are defined in equations 5 and 6.

Unsampled inflow can be calculated for individual stream segments, or for the entire study reach. A negative value for the entire study reach does not preclude positive values for some individual stream segments. If $M_{I}$ is greater than $M_{S}$ for an individual stream segment, the value of $M_{S}$ is summed for the cumulative inflow load, not the greater value of $M_{r}$.

A mean discharge-weighted concentration can be calculated for a stream segment to represent the concentration of unsampled inflow. This is accomplished by dividing the change of instream load by the change in discharge:

where:

$$
C_{\text {ICalc }}=\frac{\left(\Delta M_{S} / 0.0864\right)}{\left(Q_{B}-Q_{A}\right)}
$$

$C_{\text {ICalc }}$ is the calculated inflow concentration, in $m g / L$, and $M_{S}, 0.0864, Q_{B}$, and $Q_{A}$ are defined in equation 2 .

This mean is called a calculated inflow concentration and often may be the best value to use for lateral inflow concentrations in solute transport simulations (Kimball and others, 2003; Runkel and others, 1996a; Runkel and others, 1996b). In the absence of chemical reactions that can decrease the instream concentration, calculated inflow concentrations can 
be compared with sampled inflow concentrations to evaluate whether the sampled inflows are representative of the changes in the stream (Bencala and McKnight, 1987).

In considering estimates of stream discharge and metal concentration at each stream site, it is possible to predict an error for the change in load along a stream segment. The error is determined by the precision of both discharge and chemical measurements (Taylor, 1997), according to the equation (McKinnon, 2002):

$$
\text { Load Error }=\left(\sqrt{Q_{A}^{2} \Delta C_{A}^{2}+C_{A}^{2} \Delta Q_{A}^{2}}\right)(0.0864)
$$

where:

$C_{A}$ is the concentration error at site $A$, in $\mathrm{mg} / \mathrm{L}$,

$Q_{A}$ is the discharge error at site $A$, and

$Q_{A}, C_{A}$, and 0.0864 are already defined.

The value of $C_{A}$ is based on the single operator precision of the chemical analysis (Friedman and Erdmann, 1982). The value of $Q_{A}$ is based on the precision of the tracer concentration analysis of repeated measurements at sites that cover the range of discharge in the study reach. This results in a precision value as a function of discharge, calculated for each value of $Q_{A}$. Load error is calculated for the upstream sampling site of each stream segment and compared to the change in load for the stream segment, $M_{S}$. If the absolute value of $M_{S}$ is greater than the load error, then there has been a significant change in load. Only the values of $M_{S}$ that are greater than the load error are included in the longitudinal profiles of sampled instream load and the cumulative instream load.

\section{Alluvial Aquifer Geomorphology}

To aid the geochemical interpretation of ground and surface waters, the geomorphology of the alluvial aquifer was investigated in a companion study. The methods of this study are briefly summarized here. The alluvial aquifer was evaluated in an orientation parallel to the center of the valley bottom. Water-level profiles were constructed using ground-water levels measured in wells that penetrated the alluvial aquifer and depict the top of the aquifer at the times of the tracer studies. Water-level data and pumping data from wells were provided by Molycorp and were supplemented by water levels measured by the U.S. Geological Survey.

\section{Cluster Analysis for Sample Classification}

An important objective of synoptic sampling is to recognize patterns or chemical characteristics among samples that can indicate the sources of mine drainage. Water that interacts with a particular mineral assemblage may exhibit a characteristic chemical signature that provides distinction from other inflow samples. Thus, groups of inflow samples are identified by their similarities. In this study, this leads to the question whether inflow groups differ between mined and unmined areas.

A cluster-analysis method called partitioning around medoids was used to objectively quantify distinctions among the samples (Kaufman and Rousseeuw, 1990). The method uses a multidimensional dissimilarity measure between samples. A matrix of dissimilarity measures is minimized by forming clusters or groups of samples that minimize dissimilarity among samples within a group while distinguishing differences among groups. Total-recoverable concentrations were used as input to the analysis for inflow samples, and both dissolved and colloidal concentrations were used for stream samples. Variability among inflow chemistry often can result from the extent of water-rock interaction. This can lead to relations among variables that arise from mass-balance stoichiometry during dissolution and chemical equilibrium during precipitation. These relations often are expressed linearly in log-transformed data. Thus, the chemical concentration of each constituent, expressed in millimoles per liter, was log transformed to improve correlations that may be related to the stoichiometry of particular chemical reactions and mineral equilibrium constraints.

\section{Field-Scale Experiments}

The methods of mass-loading analysis were applied to the Red River in three separate injection reaches to investigate the entire 19,790-m study reach in 2001 and to three parts of the study reach in 2002. The study reach began at the upstream end of the town of Red River, New Mexico, and continued to the U.S. Geological Survey streamflow-gaging station 08265000, Red River near Questa, New Mexico (fig. 1). A total of 91 stream segments were chosen by walking the entire study reach, and the stream sites bracketed 62 inflow sites (McCleskey and others, 2003). Results of chemical analysis and locations of sampling sites are presented in McCleskey and others (2003); a listing of the sampling sites is presented in table 1 (located at the end of the report). Sites are referred to by their downstream distance as listed in the table. Injections were carried out in downstream to upstream order; in 2001, the most downstream, or lower injection occurred on August 16-17, the middle injection occurred on August 18-19, and the most upstream, or upper injection, occurred on August 22-24.

In the period preceding the downstream injection, substantial storms flushed sediment and solutes from the scarred areas of the watershed into the Red River and could potentially have affected the loading results. Concentrations of bromide and sulfate in samples obtained by an autosampler positioned at 13,195 $\mathrm{m}$ for the entire period of the lower and middle injections provided an indication of the stability of flow, in terms of solute variation, during the injections (fig. 2). A substantial decrease in sulfate concentration occurred at the 


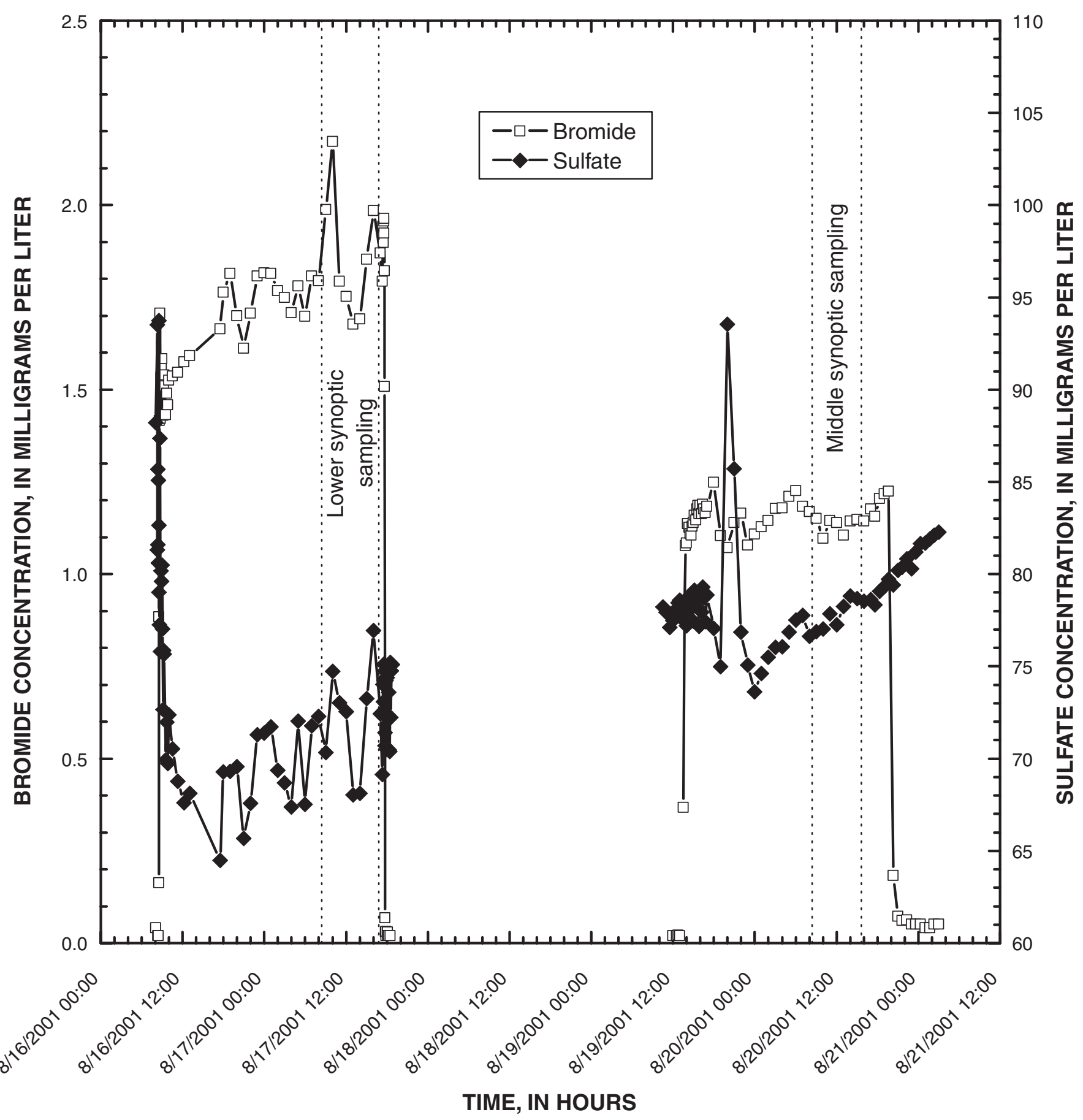

Figure 2. Variation of bromide and sulfate concentration with time during the lower and middle injection periods, Red River, New Mexico. 
start of the lower injection and could have been the tail end of a flush of dissolved salts from the storms. During synoptic sampling, indicated by vertical lines on the graph, sulfate concentration had daily variation and the minimum concentration for each daily pattern gradually increased, indicating a period of slowly decreasing discharge. No large decrease in bromide concentration occurred as it did for sulfate because bromide was injected. Bromide concentration also increased, comparable to sulfate concentration. Because the injection pumps kept the mass flux of bromide constant, that increase in concentration is due to a slow decrease in flow. These data indicate that no flushing affected the results of the synoptic sampling.

Three injection reaches were selected in 2002 to focus on particular sections of the 2001 study reach; the injection reaches included most, but not all of the 2001 study reach. The most upstream injection was started downstream from Hottentot Creek and ended upstream from the Fawn Lakes diversion on April 1. A middle injection was started downstream from the Fawn Lakes return flow and continued to a point upstream from the Mill area on March 30-31. A lower injection was started downstream from Columbine Creek and continued to a point just upstream from Bear Creek on March 29-30. Because these three injections did not include the entire study reach that was sampled in 2001, the overall reference scheme comes from the measurements made in 2001.

In this study, stream segments have been grouped to represent drainage from 15 sections along the study reach. Distance at the downstream end of each section is indicated by vertical lines in figures that show longitudinal profiles. Samples that are grouped by each of these study-reach sections are shown in table 1 (located at the end of the report). The distance and sample identification in table 1 correspond to the data base listed in McClesky and others (2003). Values of measured $\mathrm{pH}$ for stream and inflow samples are given in table 1 to indicate the sections that had acidic inflow.

\section{Discharge}

Discharge estimates, based on the six tracer injections, are shown in figure 3 . Injected bromide concentrations were substantially higher than ambient background concentrations (fig. 3). Background concentrations of bromide in sampled inflows averaged $0.03 \mathrm{mg} / \mathrm{L}$. Four inflows that had bromide concentrations comparable to the stream concentration most likely contained some stream water. Where possible, observed bromide concentrations were used with equation 1 to estimate discharge. Alternative discharge calculations were required for specific sample locations for two of the 2001 injections. First, the upper study reach, from 0 to $5,735 \mathrm{~m}$, included an 1,800 m section downstream of Pioneer Creek where bromide concentrations were nominally constant $(2,404-4,200 \mathrm{~m}$; fig. 3$)$. The lack of dilution within this section suggested a loss in flow that was indicated by velocity-area discharge measurements. A diversion of stream water to a trailer park was noted in this section of the stream. Standard tracer-dilution estimates (equa- tion 1) were developed up to the point of the flow loss $(2,404$ $\mathrm{m})$. Using the discharge estimate at $2,404 \mathrm{~m}$ as a starting point, discharge estimates for stream sites within the losing section $(2,404-4,200 \mathrm{~m})$ were developed using the observed rate of flow loss:

$$
Q_{x}=Q_{2404}^{t d}-\frac{Q_{2404}^{v a}-Q_{3350}^{v a}}{3350-2404}(x-2404)
$$

where:

$Q_{x}$ is the discharge for the site at $\mathrm{x} \mathrm{m}$ along the study reach, in $\mathrm{L} / \mathrm{s}$,

$Q_{2404}^{t d}$ is the tracer-dilution discharge at $2,404 \mathrm{~m}$, in $\mathrm{L} / \mathrm{s}$, and

$Q_{2404}^{v a}$ and $Q_{3350}^{v a}$ are the velocity-area estimates at 2,404 and $3,350 \mathrm{~m}$, in $\mathrm{L} / \mathrm{s}$.

Discharge estimates for the remaining sites, from 4,200 to $5,735 \mathrm{~m}$, were calculated using the observed bromide concentrations and equation 2.

Alternative calculations also were required in the lower study reach (12,600-19,780 m) because of an unanticipated withdrawal of water from the Red River to the mill site upstream from the injection. The removal of water was of short duration such that only a small number of sites in the middle of the study reach were affected from 16,100 to 17,480 $\mathrm{m}$. Discharge at the affected sites was estimated by interpolating between the tracer-dilution discharge estimates at 16,100 and $17,480 \mathrm{~m}$.

During the 2001 study, discharge increased by 753 $\mathrm{L} / \mathrm{s}$ along the entire $20-\mathrm{km}$ study reach. Tributary inflows accounted for 22 percent at Columbine Creek, 8 percent at Pioneer Creek, and 1 percent at Bear Creek. The remaining 69 percent was from the many seeps and springs that represent ground-water discharge to the stream. The decrease in discharge at 19,500 $\mathrm{m}$ resulted from a diversion upstream from the Forest Service buildings. The decrease shows up as a loss of load in later calculations, but was a diversion loss, rather than a loss due to reactive processes. The total increase in discharge for the segments that were sampled in 2002 was 382 $\mathrm{L} / \mathrm{s}$, but this did not represent the increase of the entire study reach.

The spatial pattern of springs and seeps suggests that there are several locations where ground-water discharge occurs, indicated by hatched boxes in figure 3 . These locations do not always correspond to physical catchments along the study reach. The most upstream zone along the study reach extended from Bitter Creek to a point downstream from Mallette Creek, at 1,510 m (fig. 1). Evidence of this zone included numerous seeps stained with white aluminum hydroxide precipitate along the right bank. A middle discharge zone ran from near Hansen Creek at 6,214 m to 7,615 m, which is a 


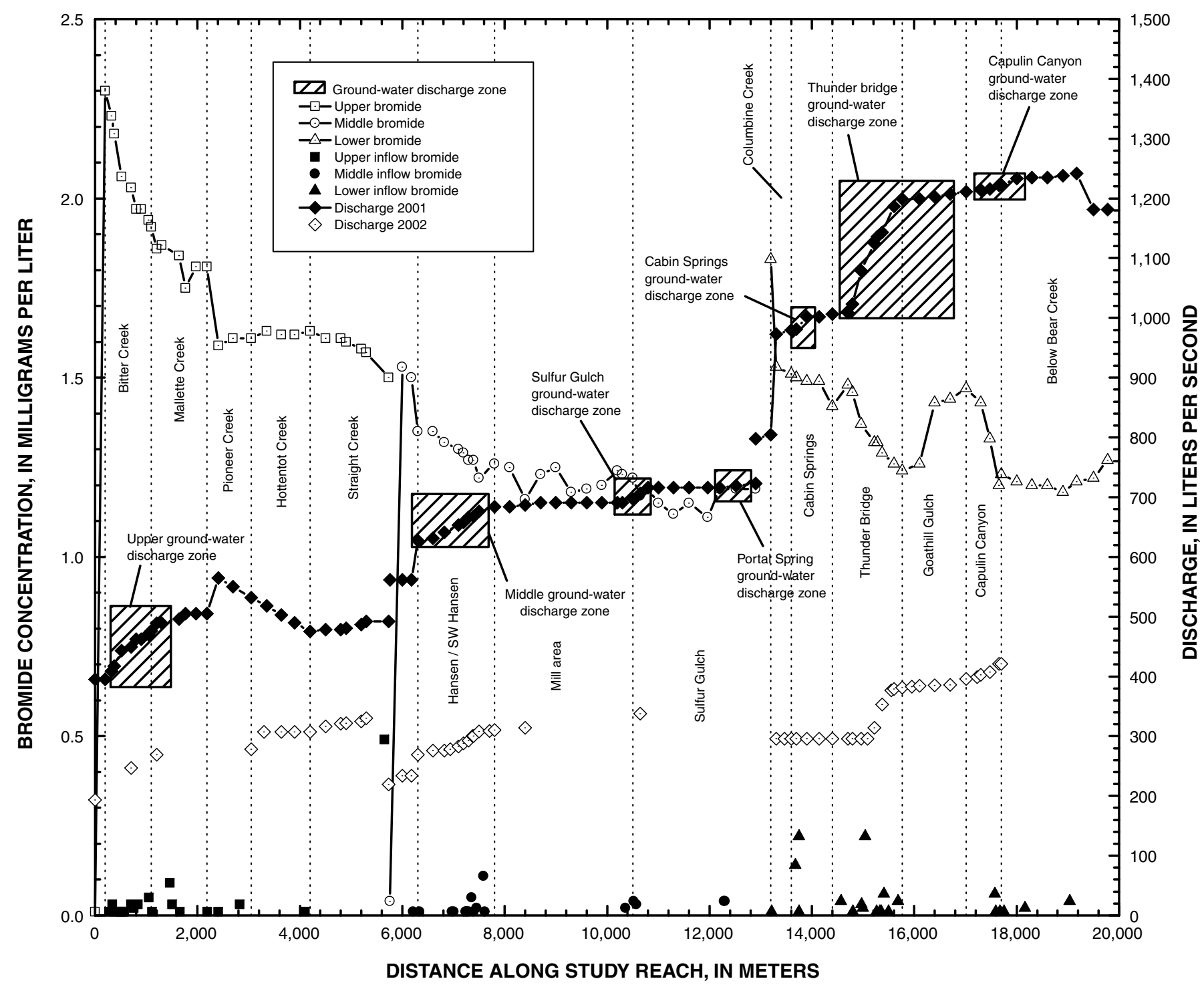

Figure 3. Variation of bromide concentration and calculated discharge with distance along the study reach, Red River, New Mexico. Principal areas of ground-water discharge are indicated.

stream site just downstream from Waldo Springs. Two smaller zones occurred near Sulfur Gulch (10,644 m) and Portal Spring $(12,515 \mathrm{~m})$. The area near Cabin Springs (13,675 m to $13,900 \mathrm{~m}$ ) included both the Cabin Springs and seeps from manganocrete in the stream bank downstream from Cabin Springs. The greatest ground-water discharge was between $14,570 \mathrm{~m}$ and $16,700 \mathrm{~m}$ in the area near Thunder Bridge, where 10 sampled springs had water flowing to the stream. Similarly, near Capulin Canyon, from 17,300 m to 18,160 m, there was inflow from several springs along the right bank and distinct inflows near Bear Creek along the left bank.

The discharge zones described above correspond to locations where the ground-water levels and the geomorphology of the canyon suggest that the alluvial aquifer should discharge to the Red River (Kirk Vincent, U.S. Geological Survey, written commun., 2005). Two alluvial facies were identified from field studies and through drilling logs. A terrace or floodplain facies was deposited by the Red River over time. This facies is interrupted by large debris-fan facies shed from tributary watersheds that contain alteration scars. The debris fans extend across the entire width of the Red River Valley and down to the bedrock base of the aquifer. The fans constitute ground-water aquitards in the shallow aquifer and account for ground-water discharge at Sulfur Gulch, Portal Springs, Thunder Bridge, and Goathill Gulch. Vincent (Kirk Vincent, U.S. Geological Survey, written commun., 2005, fig. 10) indicates water levels in the alluvial aquifer for 2001 and 2002.

These levels are based on measured water levels and pumping records from the mining operations. In the vicinity of Columbine Creek, there was an important difference between 2001 and 2002. In 2001, the water level was above the land surface, indicating discharge, but in 2002 the level at the same location was below land surface. 


\section{Chemical Variation of Synoptic Samples}

The detailed spatial sampling in 2001 and 2002 provides information about the chemical changes that occurred in the 91 stream segments along the study reach. The spatial detail of sampling was greater than in previous studies, and more constituents were sampled to help understand the system.

\section{Inflows}

Detailed inflow sampling provides the means to evaluate instream chemical changes in terms of solute sources within a catchment. Cluster analysis was used to help describe the variability among a total of 92 inflow samples from 74 sites. Results of the analysis indicate that the majority of variation among inflow samples can be described by the chemical differences among four inflow groups. Goodness of fit for the cluster analysis classification is discussed in the appendix. Chemical compositions of the groups range from high $\mathrm{pH}$ water with low metal and sulfate concentrations (inflow group 1) to low $\mathrm{pH}$ water with high metal and sulfate concentrations (inflow groups 3 and 4). Summary statistics of these inflow groups are listed in table 2. Distinctions in chemical composition among the inflow groups were substantial, particularly the differences in $\mathrm{pH}$ and concentrations of sulfate and base metals, including cadmium, copper, nickel, and zinc (fig. 4). For example, the median zinc concentration of inflow group 3 was almost 50 times greater than the median zinc concentration of inflow group 1, and the median sulfate concentration was almost 6 times greater (table 2).

Inflow group 1 includes about an equal number of left bank and right bank samples. The most prominent inflows on the left bank (draining the south side of the valley) include samples from Pioneer (2,195 m), Columbine (13,210 m), and Bear Creeks $(17,749 \mathrm{~m})$, which mostly drain areas with little alteration compared to catchments on the north side of the stream (right bank samples). Samples of group 1 are generally calcium magnesium bicarbonate type waters. This type differs from that of the samples in the other inflow groups, all of which are calcium magnesium sulfate type waters with differing concentrations. This distinction of inflow group 1 reflects the weathering of unaltered rocks, while each of the other inflow groups represents some interaction with the weathering products alteration scars.

A consistent pattern of chemical change occurred at most of the ground-water discharge zones, and is illustrated by variation in $\mathrm{pH}$ and sulfate concentrations (fig. $4 \mathrm{~A}$ and B). For example, the most upstream samples in the upper discharge zone, which are located mostly in the Bitter Creek section $(275-1,100 \mathrm{~m})$, had the chemistry of inflow group 1 (blue symbols). Inflows farther downstream had the chemistry of groups 2 (green symbols) and 3 (yellow symbols). At the middle ground-water discharge zone (mostly in the Hansen / SW Hansen section from about 6,343 $\mathrm{m}$ to $7,800 \mathrm{~m}$ ) this basic pattern was repeated. At the Thunder Bridge discharge zone
(14,570 $\mathrm{m}$ to $15,675 \mathrm{~m})$, chemical character again ranged from inflow group 1 to 3 , but also included one sample of inflow group 4 (orange symbol; 15,507 m). Finally, at the Capulin Canyon discharge area $(17,230 \mathrm{~m}$ to $17,700 \mathrm{~m})$, the pattern was different because only inflows with the chemical character of groups 3 (yellow) and 4 (orange) occurred.

There are two plausible causes for this pattern of chemical change. First, the change could result from progressive water-rock interaction, with each inflow group representing a greater extent of interaction. Alternatively, the changes could result from a progression of mixing between of water, perhaps of the type of inflow group 1, with water in the alluvial aquifer which is known to have low $\mathrm{pH}$ and solute concentrations higher than the inflows sampled in this study (LoVetere and others, 2004; Vail Engineering, 2000).

Comparison of inflow chemistry with alluvial well chemistry is helpful to distinguish among these possibilities. Median values for each inflow group (table 2) are plotted along with alluvial well concentrations in figure 5. For the variation of manganese with sulfate, the median inflow group concentrations follow a linear trend (on the log-log plot), indicated by an arrow (fig. 5A). For comparison, a line of 1:1 slope is drawn through the median concentrations of inflow group 1. Each inflow group had progressively higher concentrations that closely followed the variation in alluvial well compositions. Inflow group 1 likely represents unmixed water, unaffected by the alluvial water. On the other hand, median concentrations of inflow group 4 fall among the alluvial wells that had the highest manganese and sulfate concentrations; group 4 essentially had the same chemical character as those alluvial well waters. Thus, the variation of chemical character among inflow groups is consistent with mixing between two end members, but also indicates a changing chemical character of the alluvial well samples because the trend (arrow) has a slope greater than 1:1. This mixing with alluvial aquifer water also has been discussed by Ball and others (2005).

A possible mixing pattern also is indicated by the variation of cadmium with zinc (fig. 5B). The increase in median concentrations from group 1 to group 4 is again linear (arrow, fig. 5B). Alluvial well samples that had the lowest concentrations of cadmium and zinc plot away from the line of 1:1 slope. The well sample from Straight Creek has a much different cadmium:zinc ratio; it plots below the 1:1 slope line. Well samples that had concentrations near the median concentrations of inflow groups 3 and 4, however, plot on the line of constant 1:1 slope; they have a nearly constant solute ratio. A change in the solute ratios indicates a changing input of solutes (and water) to the alluvial water composition along the study reach. From the variations in the manganese:sulfate and cadmium:zinc ratios it would appear that the greatest changes in ratios occur between upstream wells (Elephant Rock Campground, Junebug Campground, Mill wells) and downstream wells (downstream from Sulphur Gulch). Varying solute ratios could result from regional variations in alteration mineral composition, if there were local contributions from bedrock ground water to the alluvial aquifer along the study 
Table 2. Summary statistics for inflow groups defined by cluster analysis, Red River, New Mexico

[Inflow group; classification from cluster analysis; all concentrations in milligrams per liter unless indicated]

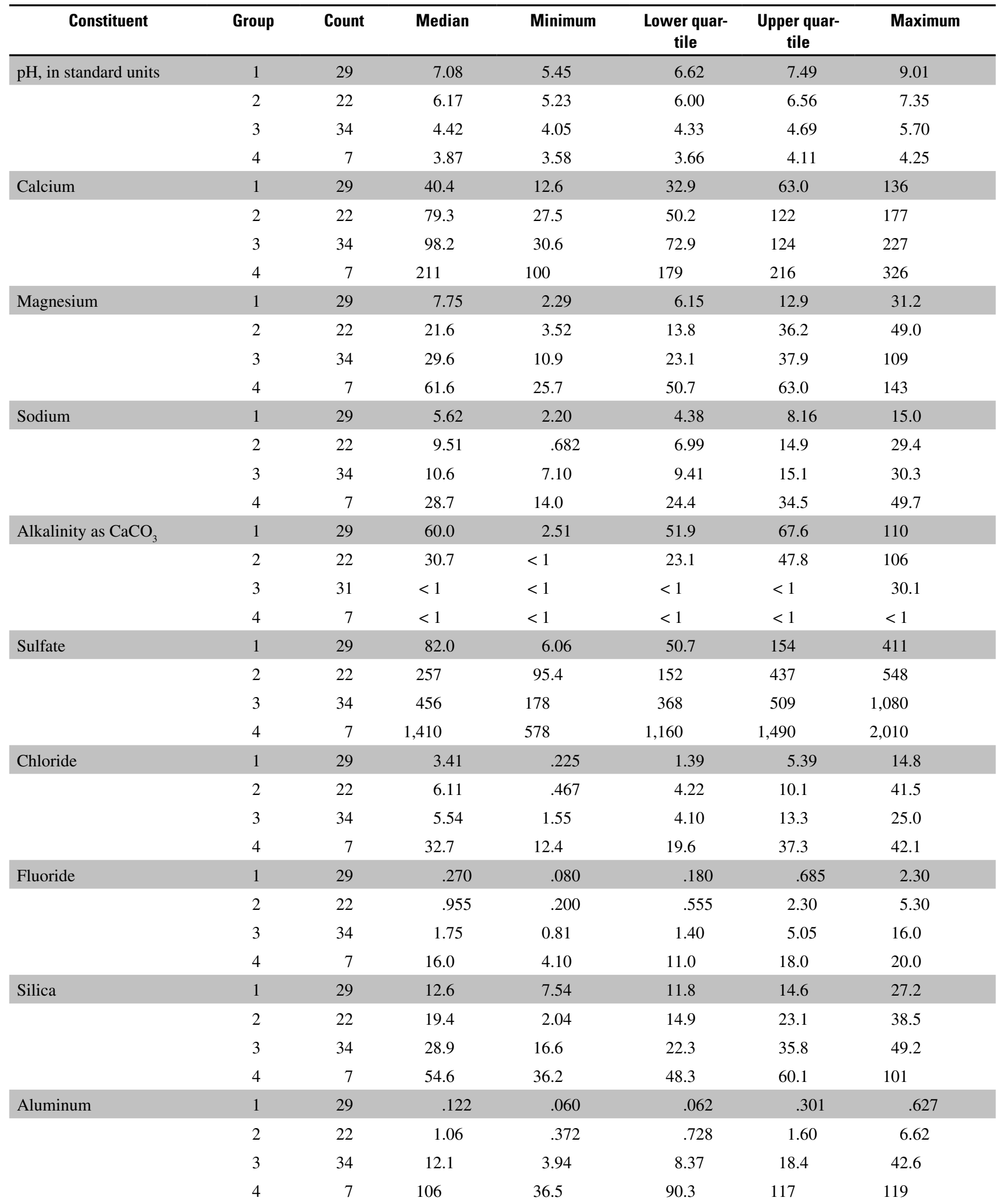


Table 2. Summary statistics for inflow groups defined by cluster analysis, Red River, New Mexico-Continued

\begin{tabular}{|c|c|c|c|c|c|c|c|}
\hline Constituent & Group & Count & Median & Minimum & $\begin{array}{l}\text { Lower quar- } \\
\text { tile }\end{array}$ & $\begin{array}{l}\text { Upper quar- } \\
\text { tile }\end{array}$ & Maximum \\
\hline \multirow[t]{4}{*}{ Cadmium } & 1 & 29 & $<.001$ & $<.001$ & $<.001$ & $<.001$ & $<.001$ \\
\hline & 2 & 22 & $<.001$ & $<.001$ & $<.001$ & .002 & .006 \\
\hline & 3 & 34 & .004 & $<.001$ & .003 & .008 & .030 \\
\hline & 4 & 7 & .021 & .008 & .017 & .024 & .026 \\
\hline \multirow[t]{4}{*}{ Copper } & 1 & 29 & $<.003$ & $<.003$ & $<.003$ & .005 & .025 \\
\hline & 2 & 22 & .007 & $<.003$ & .005 & .013 & .065 \\
\hline & 3 & 34 & .137 & .015 & .055 & .323 & .585 \\
\hline & 4 & 7 & 1.10 & .386 & 1.03 & 1.11 & 1.13 \\
\hline \multirow[t]{4}{*}{ Iron } & 1 & 29 & .122 & .004 & .035 & .379 & 5.76 \\
\hline & 2 & 22 & 3.04 & .053 & 1.02 & 6.93 & 28.3 \\
\hline & 3 & 34 & .471 & .004 & .052 & 1.87 & 5.87 \\
\hline & 4 & 5 & 27.2 & 1.13 & 3.85 & 37.1 & 41.2 \\
\hline \multirow[t]{4}{*}{ Lead } & 1 & 29 & $<.006$ & $<.006$ & $<.006$ & $<.006$ & $<.006$ \\
\hline & 2 & 22 & $<.006$ & $<.006$ & $<.006$ & .007 & .024 \\
\hline & 3 & 34 & $<.006$ & $<.006$ & $<.006$ & $<.006$ & .018 \\
\hline & 4 & 7 & $<.006$ & $<.006$ & $<.006$ & .008 & .026 \\
\hline \multirow[t]{4}{*}{ Manganese } & 1 & 29 & .017 & .001 & .007 & .073 & .443 \\
\hline & 2 & 22 & .208 & .002 & .095 & .880 & 4.22 \\
\hline & 3 & 34 & 2.25 & .352 & 1.66 & 3.06 & 23.6 \\
\hline & 4 & 7 & 14.4 & 4.86 & 13.1 & 16.1 & 16.1 \\
\hline \multirow[t]{4}{*}{ Nickel } & 1 & 29 & .003 & $<.002$ & $<.002$ & .006 & .018 \\
\hline & 2 & 22 & .032 & .003 & .020 & .094 & .215 \\
\hline & 3 & 34 & .115 & .037 & .078 & .150 & .477 \\
\hline & 4 & 7 & .417 & .135 & .347 & .445 & .782 \\
\hline \multirow[t]{4}{*}{ Strontium } & 1 & 29 & .233 & .069 & .197 & .341 & 1.61 \\
\hline & 2 & 22 & .484 & .100 & .300 & .811 & 1.51 \\
\hline & 3 & 34 & .456 & .127 & .365 & .820 & 1.25 \\
\hline & 4 & 7 & .770 & .585 & .696 & 1.03 & 1.17 \\
\hline \multirow[t]{4}{*}{ Zinc } & 1 & 29 & .014 & .005 & .005 & .039 & .122 \\
\hline & 2 & 22 & .136 & .013 & .062 & .445 & 1.56 \\
\hline & 3 & 34 & .680 & .319 & .547 & 1.41 & 4.66 \\
\hline & 4 & 7 & 3.93 & 1.31 & 3.17 & 4.22 & 4.31 \\
\hline
\end{tabular}



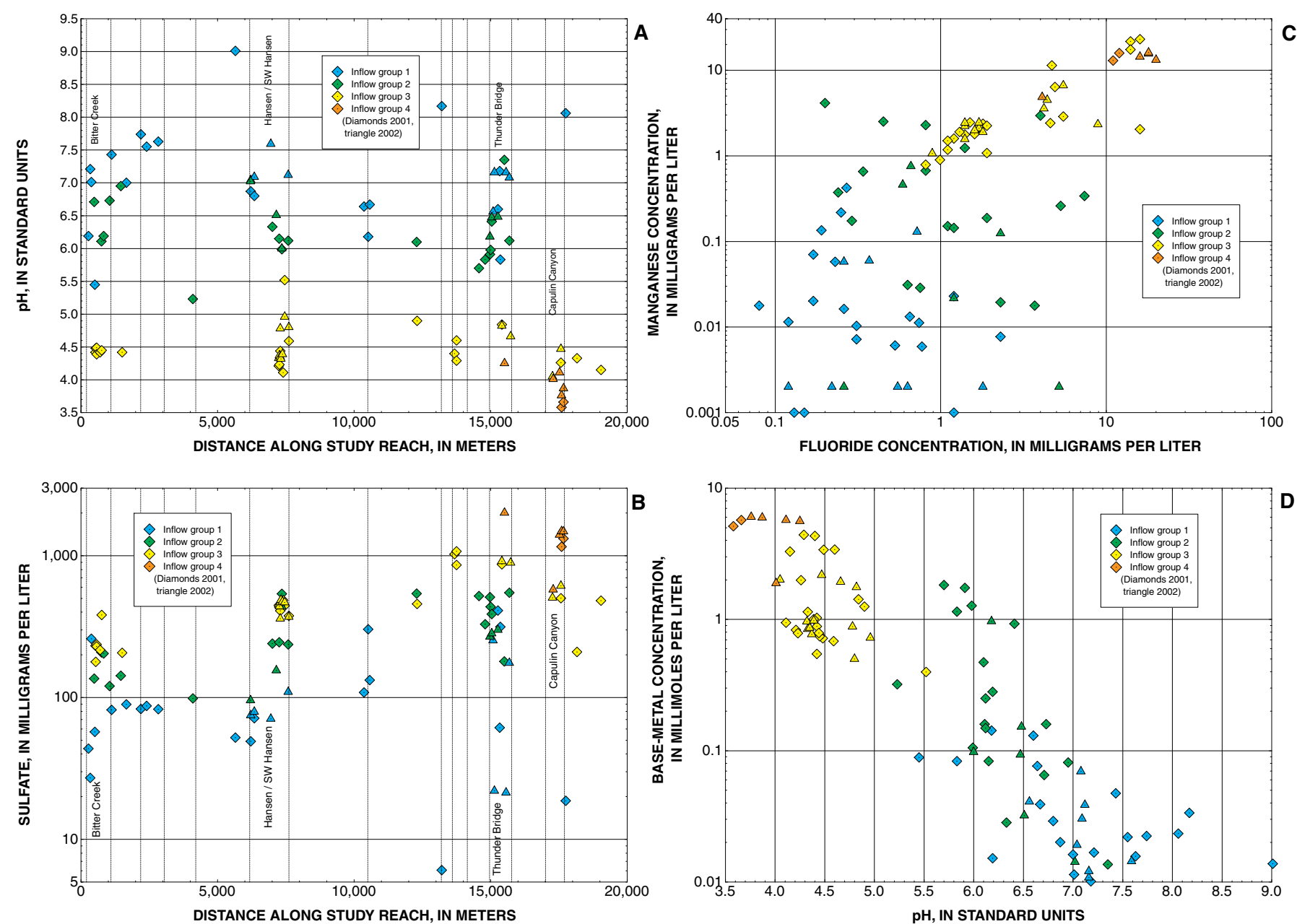

Figure 4. Variation of (A) pH and (B) sulfate concentration with distance along the study reach, (C) manganese concentration with fluoride concentration, and (D) base-metal concentration with pH for inflow samples to the Red River, New Mexico.

reach. Plumlee and others (in press) have noted that alteration minerals downstream from Columbine Creek contain greater amounts of manganese and zinc, which also is consistent with their increased concentrations in inflow water. Without a local input, solute ratios should remain constant.

The chemical character of inflow group 4 stands out from that of other inflow groups. Median concentrations of all constituents, with the exception of alkalinity, were greatest in samples from inflow group 4 (table 2). Maximum concentrations of all the metals and sulfate occurred in samples of inflow group 4, with the exception of manganese concentrations, which were highest in samples of inflow group 3 in the Cabin Springs section (table 2; fig. 4C). Inflow samples from inflow group 4 were spatially limited to one sample from the Thunder Bridge section and several samples from the Capulin Canyon section, which are both downstream from the mine area. The chemical character and spatial location of this inflow group are consistent with possible influence from mining.

\section{Stream}

Distinctions among groups of stream samples have a different implication than distinctions among groups of inflow samples. As noted, distinctions among inflows most likely result from the degree of mixing with alluvial water. Distinctions among stream groups in the Red River instead represent the chemical changes that occurred in response to inflows from the various inflow groups. Systematic changes principally occurred in the vicinity of the ground-water discharge zones (fig. 3).

Five distinct groups of stream samples were classified by cluster analysis and a summary of the variation in chemical composition among these groups is listed in table 3 . These groups principally represent spatial variation along the study reach, but also represent temporal variation between 2001 and 2002 (fig. 6). Spatially, changes in chemical character occurred at three locations in 2001 (diamond symbols). First, at $700 \mathrm{~m}$ in the upper ground-water discharge zone there was a change from stream group 1 to group 2 (see fig. 3 for 

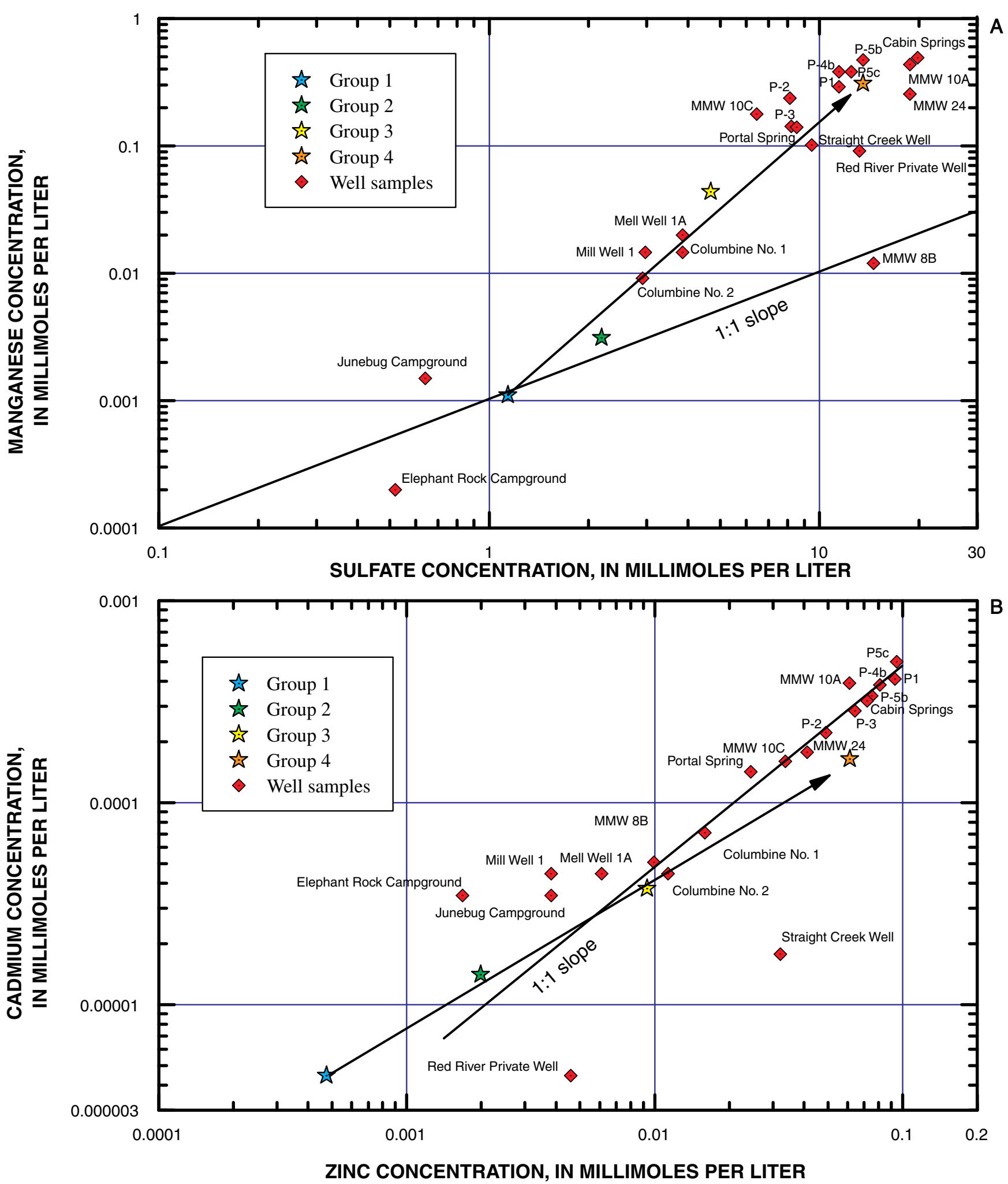

Figure 5. Variation of concentrations of $(A)$ manganese with sulfate and $(B)$ cadmium with zinc for median concentrations of inflow groups defined by cluster analysis and selected alluvial wells (LoVetere and others, 2004). 

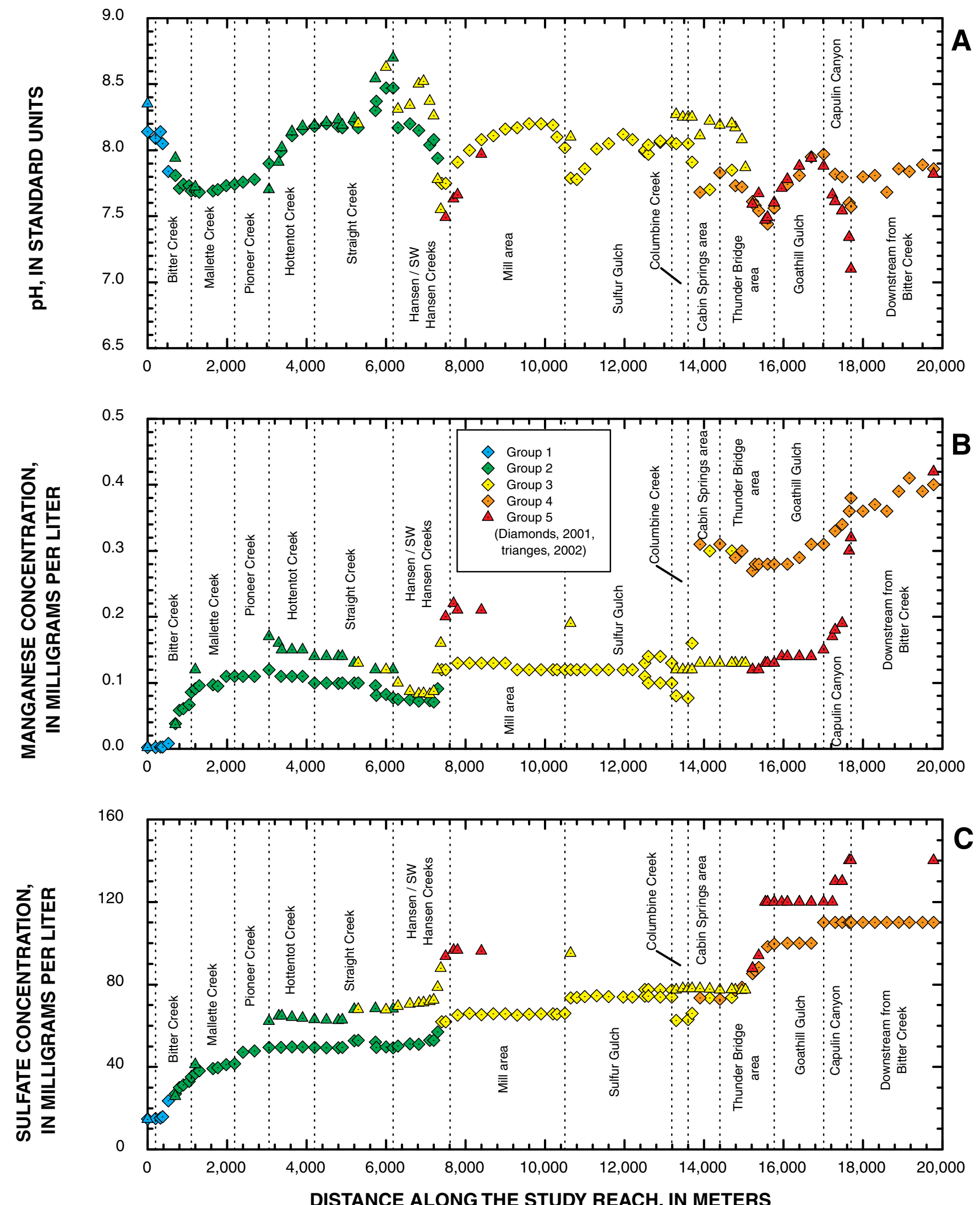

DISTANCE ALONG THE STUDY REACH, IN METERS

Figure 6. Variation of $(A) \mathrm{pH}$ and concentrations of $(B)$ manganaese and $(C)$ sulfate with distance along the study reach, Red River, New Mexico. 
Table 3. Summary of statistics for stream groups defined by cluster analysis, Red River, New Mexico [Stream group, defined by cluster analysis; all concentrations in milligrams per liter]

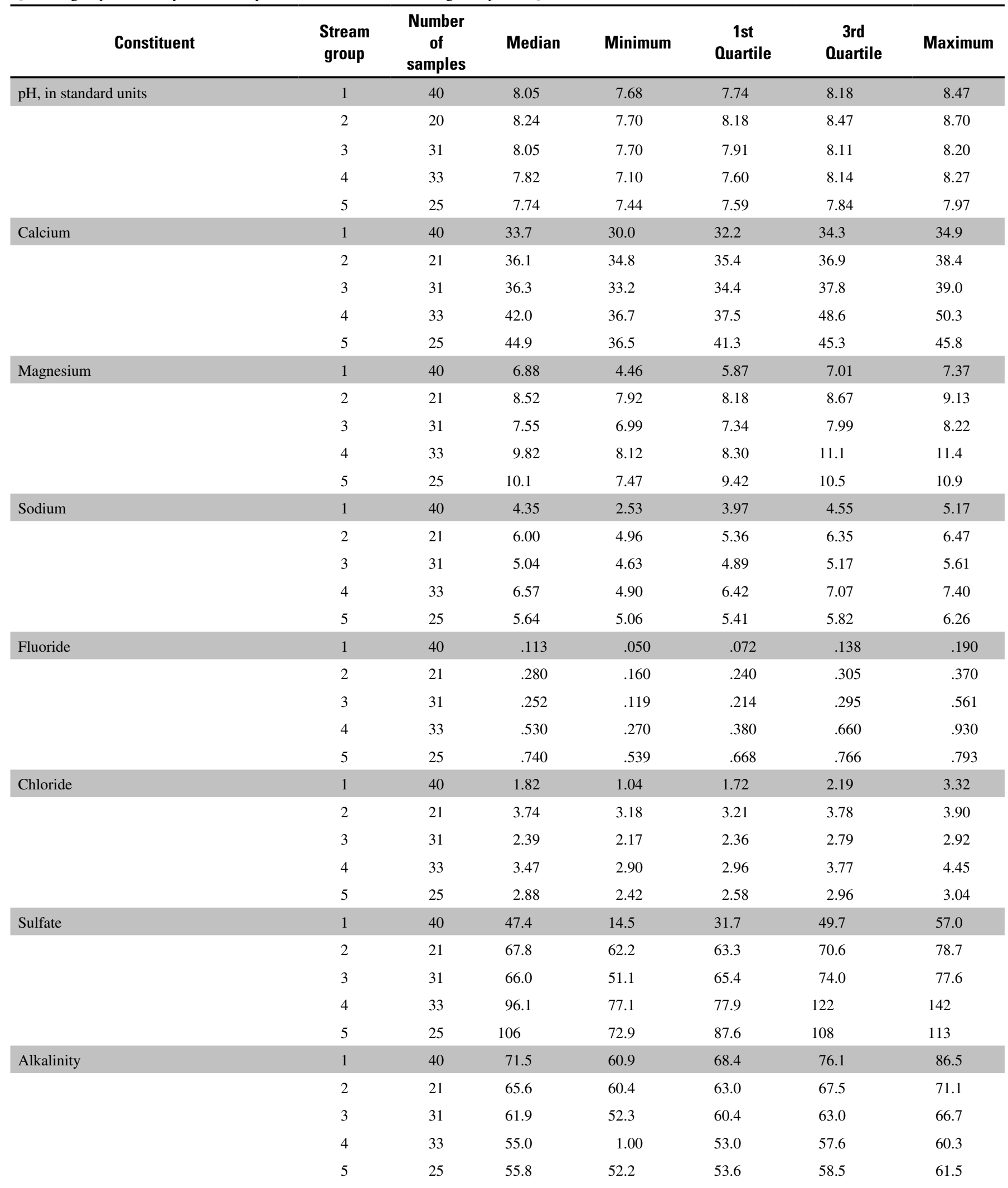


Table 3. Summary of statistics for stream groups defined by cluster analysis, Red River, New Mexico

\begin{tabular}{|c|c|c|c|c|c|c|c|}
\hline Constituent & $\begin{array}{c}\text { Stream } \\
\text { group }\end{array}$ & $\begin{array}{c}\text { Number } \\
\text { of } \\
\text { samples }\end{array}$ & Median & Minimum & $\begin{array}{c}\text { 1st } \\
\text { Quartile }\end{array}$ & $\begin{array}{c}\text { 3rd } \\
\text { Quartile }\end{array}$ & Maximum \\
\hline \multirow[t]{3}{*}{ Silica, dissolved } & 1 & 40 & 10.5 & 7.04 & 8.92 & 10.7 & 11.4 \\
\hline & 2 & 21 & 12.0 & 11.6 & 11.8 & 12.5 & 12.8 \\
\hline & 3 & 31 & 10.9 & 10.1 & 10.6 & 11.1 & 11.4 \\
\hline \multirow[t]{4}{*}{ Silica, colloidal } & 1 & 40 & $<.01$ & $<.01$ & $<.01$ & .028 & .531 \\
\hline & 2 & 21 & .385 & .025 & .179 & .729 & .860 \\
\hline & 3 & 31 & $<.01$ & $<.01$ & $<.01$ & $<.01$ & $<.01$ \\
\hline & 4 & 33 & 1.04 & $<.01$ & .720 & 1.48 & 2.29 \\
\hline \multirow{3}{*}{ Aluminum, dissolved } & 3 & 31 & .168 & .100 & .146 & .185 & .239 \\
\hline & 4 & 33 & .133 & .073 & .117 & .153 & .454 \\
\hline & 5 & 25 & .184 & .131 & .166 & .221 & .333 \\
\hline \multirow[t]{5}{*}{ Aluminum, colloidal } & 1 & 40 & .201 & 0.000 & .164 & .233 & .288 \\
\hline & 2 & 21 & .300 & .099 & .245 & .354 & .456 \\
\hline & 3 & 31 & .500 & .329 & .453 & .604 & .963 \\
\hline & 4 & 33 & .605 & .401 & .518 & .810 & 2.23 \\
\hline & 5 & 25 & 1.64 & .958 & 1.13 & 1.83 & 2.08 \\
\hline Copper, dissolved & 1 & 40 & .005 & .003 & .004 & .006 & .013 \\
\hline \multirow{3}{*}{ Copper, colloidal } & 3 & 31 & .004 & .002 & .004 & .006 & .009 \\
\hline & 4 & 33 & .004 & 0.000 & .002 & .007 & .020 \\
\hline & 5 & 25 & .011 & -.013 & .008 & .014 & .015 \\
\hline \multirow[t]{5}{*}{ Iron, dissolved } & 1 & 40 & .005 & .004 & .004 & .010 & .069 \\
\hline & 2 & 21 & .007 & .007 & .007 & .007 & .117 \\
\hline & 3 & 31 & .004 & .004 & .004 & .004 & .035 \\
\hline & 4 & 33 & .007 & .007 & .007 & .010 & .121 \\
\hline & 5 & 25 & .004 & .004 & .004 & .005 & .007 \\
\hline \multirow[t]{5}{*}{ Iron, colloidal } & 1 & 40 & .219 & .029 & .075 & .317 & .570 \\
\hline & 2 & 21 & .341 & .160 & .252 & .410 & .578 \\
\hline & 3 & 31 & .633 & .472 & .575 & .842 & 1.50 \\
\hline & 4 & 33 & .190 & .140 & .170 & .232 & .450 \\
\hline & 5 & 25 & 1.77 & 1.21 & 1.56 & 2.63 & 3.18 \\
\hline
\end{tabular}


Table 3. Summary of statistics for stream groups defined by cluster analysis, Red River, New Mexico

\begin{tabular}{|c|c|c|c|c|c|c|c|}
\hline Constituent & $\begin{array}{l}\text { Stream } \\
\text { group }\end{array}$ & $\begin{array}{c}\text { Number } \\
\text { of } \\
\text { samples }\end{array}$ & Median & Minimum & $\begin{array}{c}\text { 1st } \\
\text { Quartile }\end{array}$ & $\begin{array}{c}\text { 3rd } \\
\text { Quartile }\end{array}$ & Maximum \\
\hline \multirow[t]{3}{*}{ Manganese, dissolved } & 1 & 40 & .091 & .001 & .063 & .102 & .115 \\
\hline & 2 & 21 & .130 & .083 & .091 & .145 & .167 \\
\hline & 3 & 31 & .123 & .072 & .120 & .133 & .302 \\
\hline \multirow[t]{4}{*}{ Manganese, colloidal } & 1 & 40 & .007 & .001 & .002 & .011 & .018 \\
\hline & 2 & 21 & .010 & .002 & .006 & .013 & .029 \\
\hline & 3 & 31 & .014 & .005 & .013 & .018 & .052 \\
\hline & 4 & 33 & .016 & .001 & .010 & .022 & .032 \\
\hline \multirow{3}{*}{ Nickel, dissolved } & 3 & 31 & .005 & .002 & .005 & .005 & .007 \\
\hline & 4 & 33 & .012 & .006 & .007 & .013 & .018 \\
\hline & 5 & 25 & .015 & .007 & .013 & .016 & .019 \\
\hline \multirow[t]{5}{*}{ Strontium, dissolved } & 1 & 40 & .190 & .164 & .181 & .200 & .215 \\
\hline & 2 & 21 & .228 & .219 & .226 & .233 & .242 \\
\hline & 3 & 31 & .210 & .188 & .200 & .219 & .229 \\
\hline & 4 & 33 & .246 & .221 & .227 & .280 & .288 \\
\hline & 5 & 25 & .258 & .214 & .241 & .266 & .277 \\
\hline Zinc, dissolved & 1 & 40 & .013 & .004 & .008 & .027 & .042 \\
\hline \multirow{3}{*}{ Zinc, colloidal } & 3 & 31 & .017 & .009 & .013 & .018 & .029 \\
\hline & 4 & 33 & .018 & .005 & .014 & .023 & .086 \\
\hline & 5 & 25 & .045 & 0.000 & .039 & .050 & .059 \\
\hline
\end{tabular}


discharge zones). This first change most likely represents discharge of ground water from Bitter Creek and results in a decrease of $\mathrm{pH}$ and an increase in concentrations of manganese and sulfate by about three times (fig. 6B and C). Concentrations of other metals also increased (table 3). Second, at about 7,300 $\mathrm{m}$, in the middle ground-water discharge zone, a change from stream group 2 to group 3 occurred, again with a decrease of $\mathrm{pH}$ and an increase in concentrations of manganese and sulfate. Ground-water discharge and the subsequent change in stream chemistry at the middle ground-water discharge zone may include drainage from the hydrothermal scars in Hottentot, Straight, Hansen and southwest Hansen Creeks, all of which occur upstream from this zone. These catchments had no surface-water inflow to the Red River at their confluences at the time of synoptic sampling in 2001. Investigation has suggested that the ground-water discharge from Straight Creek does not enter directly into the Red River alluvium near the confluence, but instead bends to flow down-valley (C. Naus, U.S. Geological Survey, written commun., 2003). This middle discharge zone is the likely discharge location for this water. Finally, between 13,900 $\mathrm{m}$ and 14,400 $\mathrm{m}$ in the Cabin Springs and Thunder Bridge areas, which both include ground-water discharge zones, there was a change from stream group 3 to group 4. The same pattern of decreasing $\mathrm{pH}$ and increasing concentrations of manganese and sulfate occurred at this third location.

Temporally, chemical distinctions between samples from 2001 and 2002 occurred even though the overall spatial patterns were comparable. Generally, concentrations of manganese and sulfate were higher in 2002 (triangles) than in 2001 (diamonds; figs. 6B and C). The chemical character changed from that of stream group 1 to stream group 2 in the upper ground-water discharge zone, as in 2001 (table 3; fig. 6 ). The change from the character of group 2 to that of group 3 , however, occurred farther upstream in 2002, between 5,200 $\mathrm{m}$ and $6,300 \mathrm{~m}$, instead of between $7,295 \mathrm{~m}$ to $7,395 \mathrm{~m}$ as in 2001. A second change occurred within the middle groundwater discharge zone, between 7,377 $\mathrm{m}$ and 7,500 $\mathrm{m}$. This was a change from the chemical character of group 3 to that of group 5, which had substantially higher concentrations of most constituents than group 4 (table 3 ). As noted above, the substantial increase in manganese in the Cabin Springs section in 2001 did not occur in 2002 (fig. 6B). Instead, manganese concentration remained nearly constant through the Cabin Springs section, and so there was not a change in chemical character at $13,900 \mathrm{~m}$ as there had been in 2001. Despite the lack of change in the Cabin Springs section in 2002, a substantial change in $\mathrm{pH}$ and sulfate concentration did occur in the Thunder Bridge section as it did in 2001 (between 15,048 m and $15,221 \mathrm{~m})$, and the chemical character of the stream water changed from that of stream group 3 to that of group 5. Manganese concentration did increase in the Capulin Canyon area in 2002, even to the same level as measured in 2001 (fig. 6B). This temporal shift was similar to that which occurred in the middle ground-water discharge zone; the change resulted from higher instream concentrations during lower flow conditions.
No clear differences occurred between the inflow concentrations from 2001 and 2002, so the higher concentrations of manganese, sulfate, and base metals, as well as lower $\mathrm{pH}$ in stream, represented by stream group 5, represent the effect of less stream water receiving the same inflow concentrations.

\section{Load Profiles}

Detailed longitudinal profiles of loading along the study reach can be prepared from the results of the field-scale experiments. These profiles indicate the location of the loads entering the stream and quantify the relative size of the loads. Although the three separate injection reaches were studied on different days and storms occurred during the period of study, the combination of results from all three injections can be unified to present a profile for the entire stream. This combination was accomplished by calculating significant changes (using equation 9) for each stream segment within each injection reach. These significant changes were then summed sequentially along the upper injection reach. The resulting load at the end of the upper injection reach was then used as the starting load for the middle injection reach and the significant loads for that injection reach were added sequentially to the sum. Likewise, the sum of changes at the end of the middle injection reach was used as the starting load for the lower injection reach and the significant loads in that reach were added. Thus, loading profiles herein do not represent the absolute load, but a sequential sum of significant changes in load. With the profiles it is possible to evaluate temporal and spatial changes.

\section{Load in 2001 versus 2002}

Both similarities and differences are evident when comparing the cumulative instream load profiles of manganese and sulfate for 2001 and 2002 (fig. 7). With the exception of the Cabin Springs area, manganese load increased at all the same locations in both years. Patterns from both years indicate increases at Bitter Creek (upper ground-water discharge zone), Hansen and Southwest Hansen Creeks (middle zone), Thunder Bridge, Capulin Gulch, and downstream from Bear Creek. The difference in magnitude of manganese loading between 2001 and 2002 could be a result of drought conditions, which were more severe in 2002 than 2001, and resulted in smaller loads in 2002. Based on the cumulative instream load for each of these locations, the percentage increase for each of the principal locations of loading was comparable for both years.

The difference between 2001 and 2002 in the Cabin Springs area most likely resulted from a combinination of the removal of water from the alluvial aquifer by pumping for the mining operation and differences between antecedent conditions for the two mass-loading studies. Water levels in the alluvial aquifer at that location were below ground surface in 2002 (Kirk Vincent, U.S. Geological Survey, written commun., 2005). Pumping rates in August 2001 averaged 11.3 L/s, compared to $54 \mathrm{~L} / \mathrm{s}$ in March 2002 (Christoph Wels, 
Robertson GeoConsultants Inc, written commun., 2005). Climatically, the 2001 mass-loading studies followed a period of rain, making discharge from seeps and springs greater than in 2002, when the tracer injection followed a period of very little precipitation. Vail Engineering (2000) suggested that pumping the alluvial aquifer for mining operations results in an improvement of the water quality in the Cabin Springs area, and this observed change in manganese loading is consistent with that suggestion.

\section{Principal Locations of Mass Loading}

Load profiles from 2001 are used for the discussion of mass-loading patterns because they are continuous along the entire study reach, and, with the notable exception for Cabin Springs, the trends of profiles were comparable between 2001 and 2002. Patterns of mass loading for each constituent indicate many details, but when considered together general patterns are evident, and these general patterns are illustrated using the loading profiles of sulfate, alkalinity, fluoride, aluminum, manganese, and zinc.

\section{Sulfate}

Mass loading of sulfate provides much detail about locations of loading along the study reach (fig. 8). Similar locations for loading of sulfate are apparent in the load profile of Vail Engineering (2000), but additional discharge zones were identified in this study. In the loading profile of figure 8 , and in subsequent plots of loading, the longitudinal profile includes the dissolved load (from equation 4) and the cumulative instream load. For metals, the colloidal load (also from equation 4 using colloidal concentrations) is included. These profiles include calculations for each stream segment along the study reach, and the section locations are indicated by vertical lines on the graph. The contribution of sampled inflow (equation 6), unsampled inflow (equation 7), and mass loss (negative values of equation 5) are summed for each of the sections in figure $8 \mathrm{~B}$.

Each of the 15 sections had some loading of sulfate, but 72 percent of the sulfate load occurred in just four sections, including Bitter Creek (the upper ground-water discharge zone), Straight Creek and the Hansen Creeks (the middle ground-water discharge zone), Cabin Springs, and Thunder Bridge (both in downstream ground-water discharge zones). The Thunder Bridge section alone accounts for one third of the sulfate loading along the study reach (fig. 8B). Contribution from Hottentot Creek was small compared with the other sections where alteration scars were prominent. Both the Straight Creek and Sulfur Gulch sections had about half their loading as unsampled inflow, which could indicate groundwater inflow. Sulfate was the only major ion that did not have a substantial load at the beginning of the study reach (first bar in fig. 8B), which demonstrates the lack of source minerals upstream from the alteration scars.
Dissolved and cumulative instream loads for sulfate and most metals increased substantially in the reach of the Red River from about 7,200-8,000 m, in the general vicinity of the La Bobita campground (roughly at about 7,900 m). This section contains sediments retained behind a narrowing of the canyon by bedrock on both sides, which would retard the flow of ground water and force it to discharge to the stream (Kirk Vincent, U.S. Geological Survey, written commun., 2005). Supporting evidence for such upwelling would be water levels in the La Bobita well that matched those in the Red River and water chemistry that matched that in the Hansen well. Preliminary data indicate that the water levels are the same (C. Naus, U.S. Geological Survey, written commun., 2003). Mass ratios for dissolved constituents in the Hansen well water are compared to those in the La Bobita well water (fig. 9). Each of the solute mass ratios plots close to the line that indicates an equal mass ratio. This correspondence indicates a close similarity in water chemistry that most likely results from the mixing of ground water from the Hansen section with ground water from La Bobita.

The calculated inflow concentration (equation 8) for each of the 15 study-reach sections is compared with the median and range of sampled inflow concentrations, and to concentrations from sampled alluvial wells (LoVetere and others, 2004) in figure 10. Comparing sampled inflow concentrations to the calculated inflow concentration indicates whether sampled inflows adequately account for mass loading to the stream. For example, the median sulfate concentration of inflow samples collected between $14,958 \mathrm{~m}$ and $15,795 \mathrm{~m}$, in the Thunder Bridge area, was $410 \mathrm{mg} / \mathrm{L}$, with a range from 61 to $870 \mathrm{mg} / \mathrm{L}$ (fig. 10A). This median was 41 percent greater than the calculated inflow concentration for sulfate, which was $290 \mathrm{mg} / \mathrm{L}$. The calculated inflow concentration, however, was within the range of sampled inflow concentrations, so that the sampled inflows may be considered representative in the Thunder Bridge section. Median inflow concentrations of sulfate for the Hottentot and Straight Creek sections were 99 and $51 \mathrm{mg} / \mathrm{L}$, respectively, which was low compared to the high sulfate concentrations in the alluvial wells. This could suggest that little alluvial water enters the stream in those sections. Inflow samples from the Hansen and Southwest Hansen sections, however, had a median sulfate concentration of $409 \mathrm{mg} / \mathrm{L}$, which was substantially higher, but still lower than sulfate concentrations in water from alluvial wells. Along with the correspondence of mass ratios (fig. 9), the substantial increase in the median sulfate concentration is consistent with mixing of the higher alluvial water concentrations with more dilute water, and could signal discharge of alluvial water. The same pattern of increase for inflow samples in the Hansen Creeks area also occurred for aluminum and manganese (fig. 10B and C). The substantial increase of sulfate load in the sections from Cabin Springs through Capulin Canyon was consistent with higher sulfate concentrations in sampled inflows. Calculated inflow concentrations of sulfate were comparable to the median sample concentrations, and generally fell in the range 

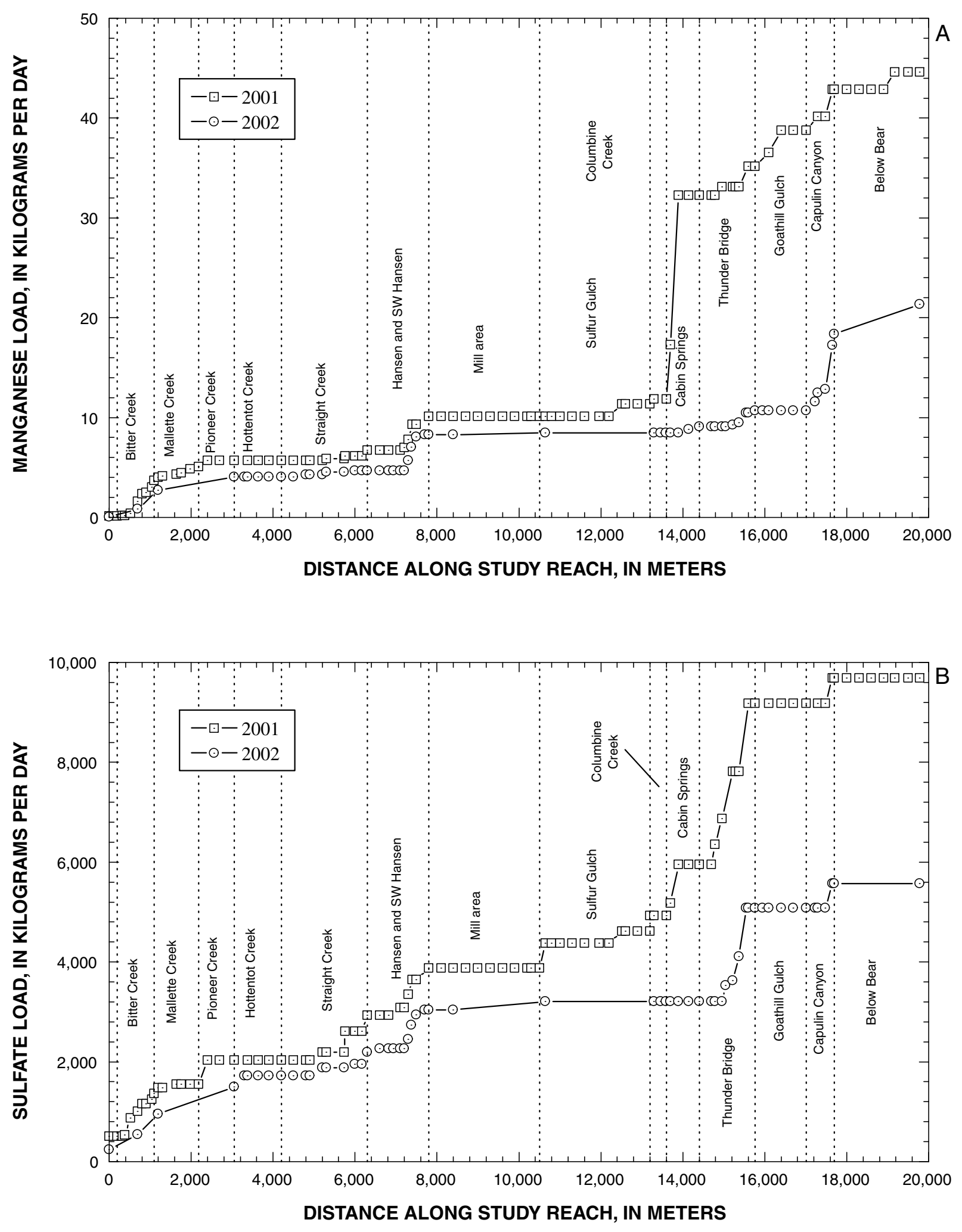

Figure 7. Variation of cumulative instream load of (A) manganese and (B) sulfate with distance along the study reach for 2001 and 2002, Red River, New Mexico. 

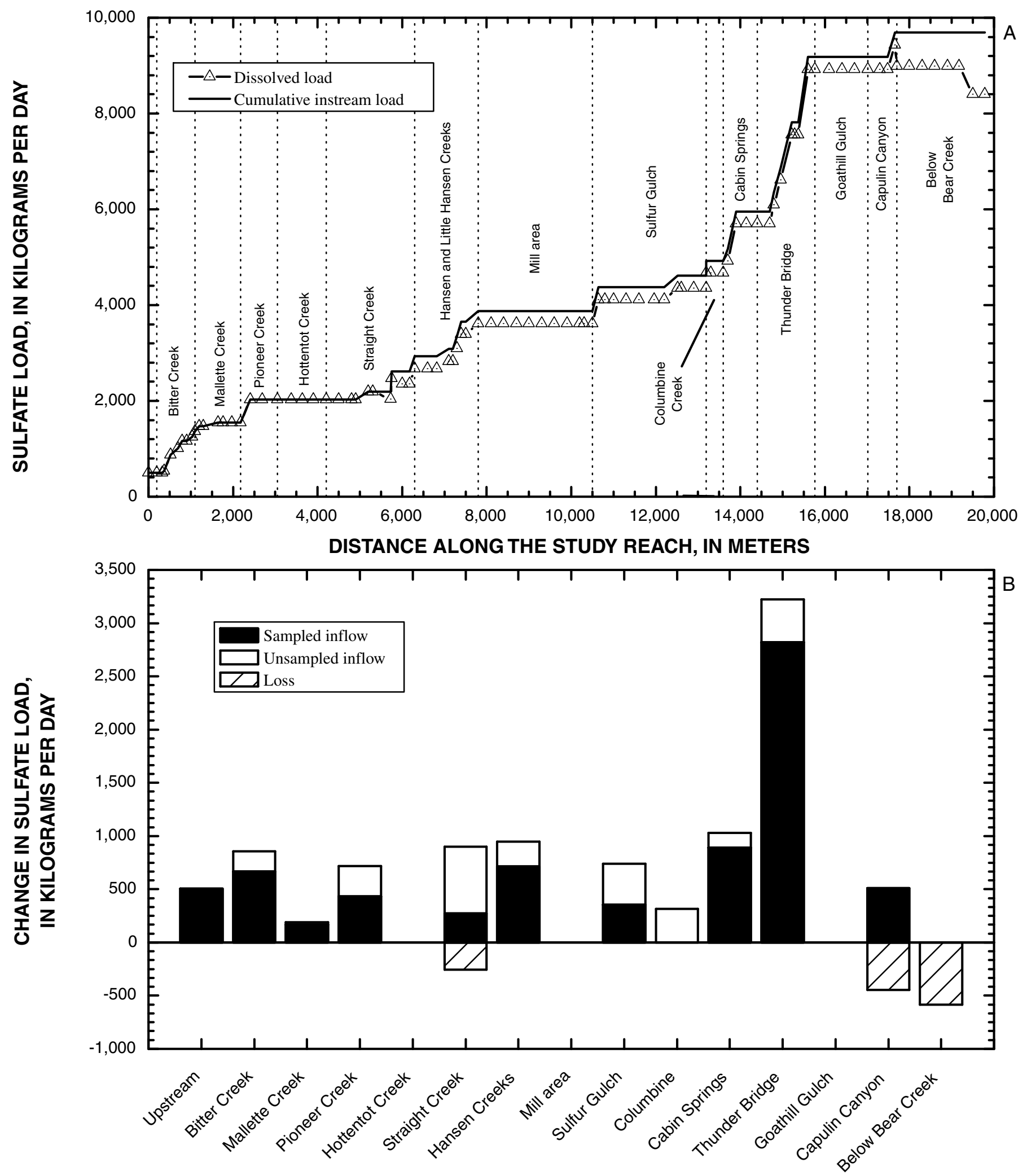

\section{SECTION}

Figure 8. Variation of (A) sulfate load with distance along the study reach and (B) change in sulfate load for individual sections along the Red River, New Mexico, August 2001. 


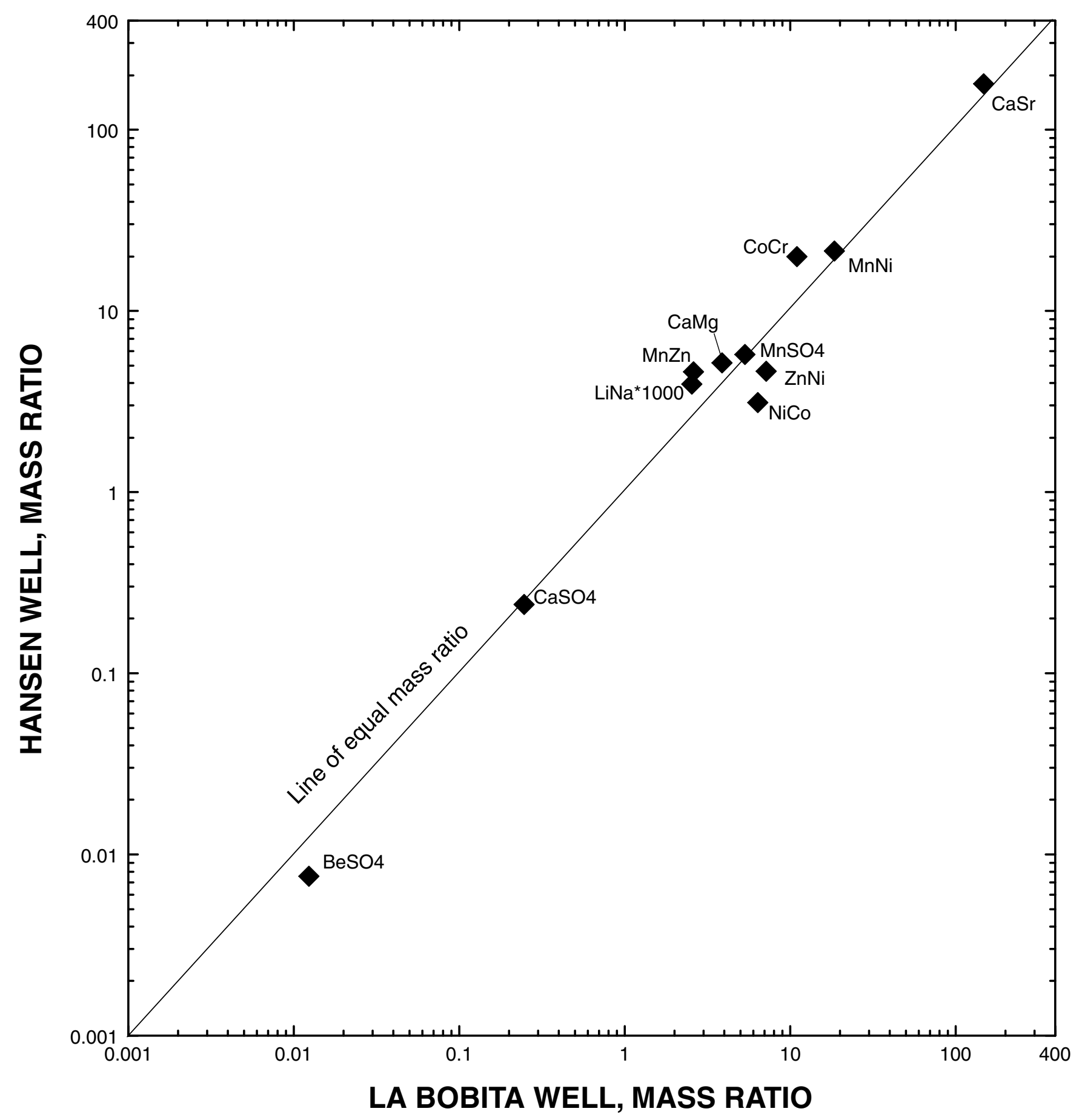

Figure 9. Comparison of mass ratios for selected solute pairs in water from La Bobita Camground well and the Hansen alluvial well, near the Red River, New Mexico (from Ball and others, 2005, fig. 12). 

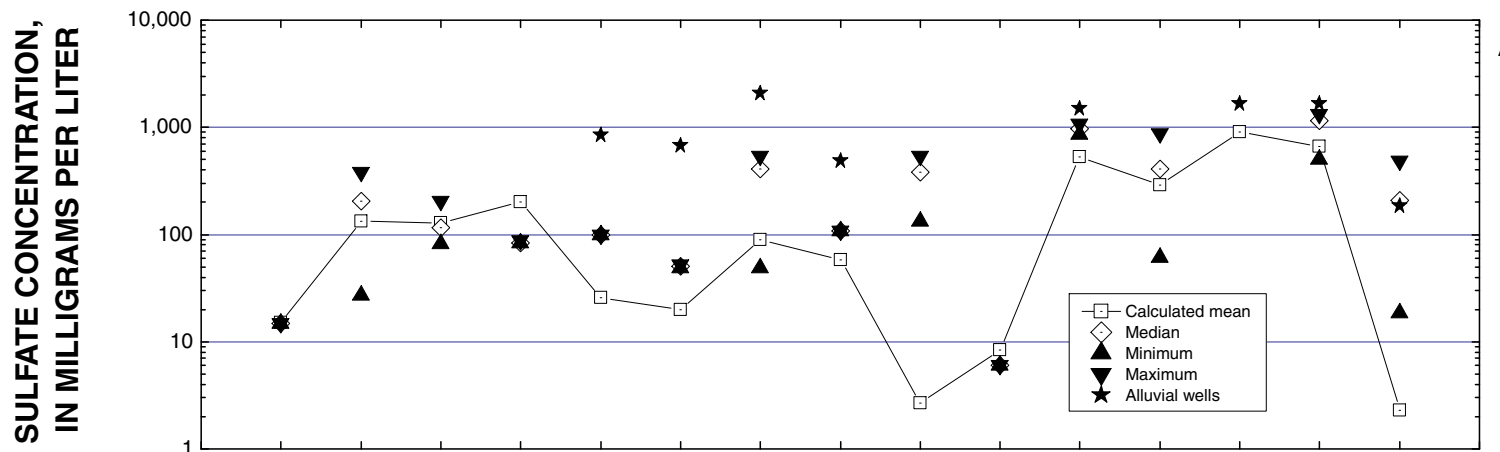

A

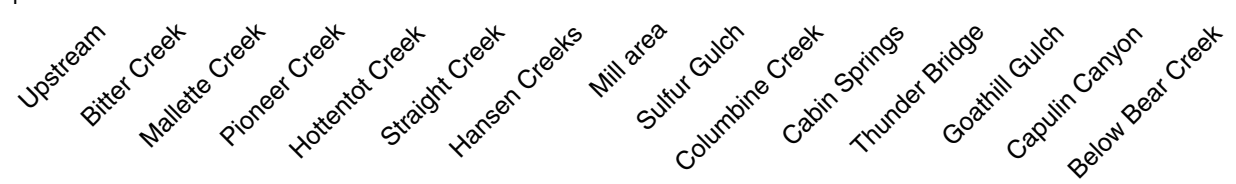

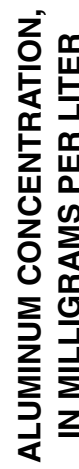
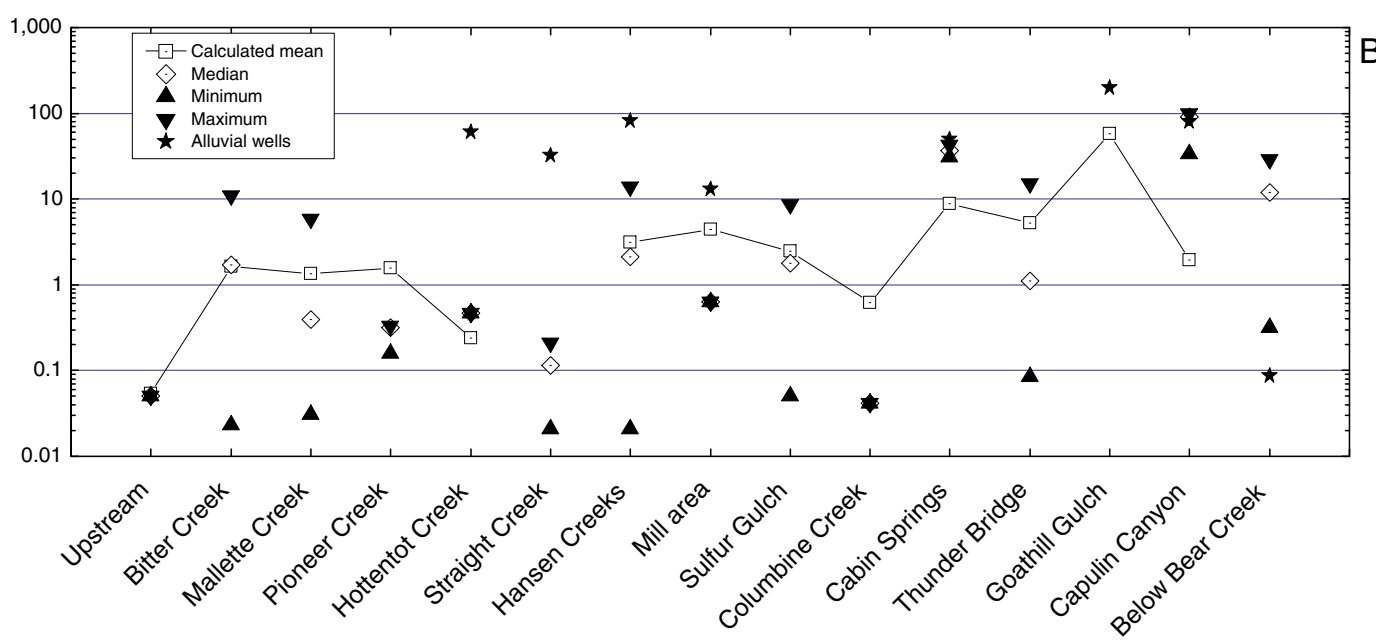

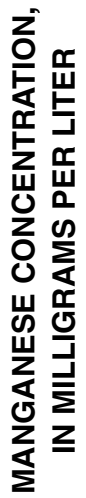

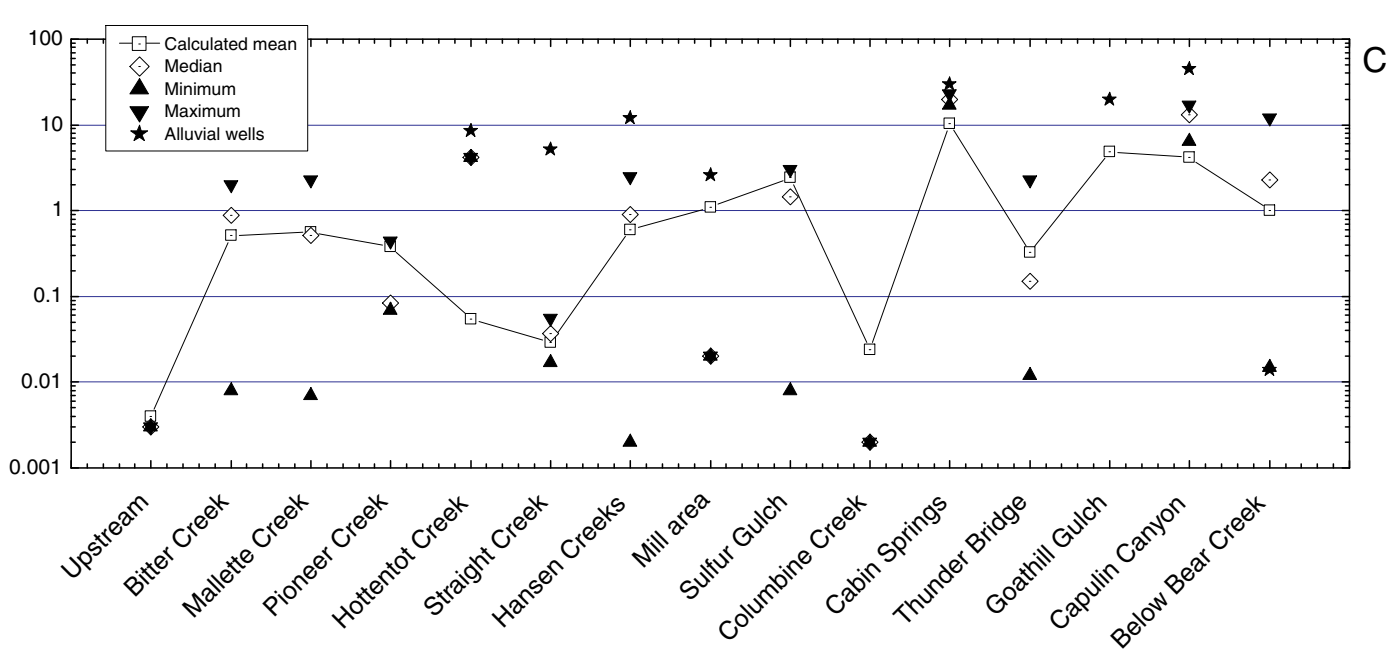

CATCHMENT

Figure 10. Relation of calculated inflow concentration and sampled alluvial well concentrations to median, minimum, and maximum inflow concentrations for (A) sulfate, (B) aluminum, and (C) manganese in sections along the Red River, New Mexico. 
of sampled inflow concentrations for each of these study-reach sections.

\section{Alkalinity}

Mass loading of alkalinity differs from that of sulfate because it occurred within sections of the study reach where the load of sulfate generally did not increase substantially. Alkalinity loading was greatest upstream from the study reach, as indicated by the load of $2,800 \mathrm{~kg} /$ day at the far left of the loading profile of alkalinity (fig. 11A). The Columbine Creek catchment also contributed a load of more than $1,500 \mathrm{~kg} /$ day (fig. 11B). Both these loads reflect the weathering of bedrock that lacks the alteration minerals found in catchments with the scars. Such bedrock weathering contributes to the loads of calcium, magnesium, chloride, silica, barium, and strontium. Loading of alkalinity was smaller from those sections affected by scars, either because they lacked the same bedrock minerals or because alkalinity was consumed in buffering acidic drainage.

\section{Fluoride}

The loading pattern of fluoride is similar to that of sulfate with most of the loading from the mine site reach, principally in the Cabin Springs and Thunder Bridge sections (fig. 12). This loading corresponds to the elevated fluoride concentrations found in inflows and wells (fig. 4C) in those areas (LoVetere and others, 2004), and upstream from Cabin Springs near Sulfur Gulch (Christoph Wels, Robertson GeoConsultants Inc, written commun., 2005). The mineralogical residence of fluoride most likely is fluorite (Plumlee and others, 2005), fluorphlogopite, and fluoride-rich sericite (Christoph Wels, Robertson GeoConsultants Inc, written commun., 2005). Among these, fluorite is likely to weather the most rapidly and would be the likely source of fluoride for this loading to the stream. The large increase in load in the Cabin Springs and Thunder Bridge sections likely comes from weathering of fluorite and a change in the fluoride to chloride ratio, particularly downstream from 13,900 m (McCleskey and others, 2003), suggests that the source of fluoride from that point on downstream differs from sources upstream from there. Some fluoride loading came from alteration scar drainage upstream from the mine site, but the additional loading in the Cabin Springs and Thunder Bridge sections was about 7 times greater than that from the upstream scar drainages (fig. 12B).

\section{Aluminum}

The loading profile for aluminum indicates that almost no aluminum load entered the study area from upstream sources (fig. 13). Instead, mass loading of aluminum principally occurred in the Hansen Creeks, Cabin Springs, Thunder Bridge, Goathill Gulch, and Capulin Canyon sections, which all correspond to ground-water discharge zones (fig. 3). Aluminum in the ground water most likely results from the dissolution of unaltered bedrock and gangue minerals by acid that is generated during pyrite oxidation (Nordstrom and Alpers, 1999). Unlike sulfate and alkalinity, aluminum loads are almost entirely in the colloidal phase in the stream (fig. 13A). The strong tendency for aluminum to form colloids has been observed in many studies (Broshears and others, 1996; Davis, 1988; Kimball and others, 1995; Nordstrom and Ball, 1986). As this colloidal material is trapped in the biofilm on cobbles and strained on the bed during hyporheic exchange (Worman and others, 2002), the streambed gains a characteristic white color. Mass loss of aluminum is particularly important in the areas of Capulin Gulch and downstream from Bear Creek (fig. 13B). The loads indicated in figure 13B for Capulin Canyon and below Bear are minimum loads because of the substantial loss of aluminum that occurs to the streambed in those sections. Formation of colloidal aluminum hydroxides is physically toxic to fish (Besser and others, 2001; Witters and others, 1996).

Aluminum concentrations in water from alluvial wells were higher than calculated inflow concentrations of aluminum (fig. 10B). The median concentration in water from alluvial wells was $58 \mathrm{mg} / \mathrm{L}$ and the median of calculated inflow concentrations was $2.9 \mathrm{mg} / \mathrm{L}$. Only the calculated inflow concentrations for Cabin Springs and Goathill Gulch were greater than $10 \mathrm{mg} / \mathrm{L}$. Such a difference most likely reflects the loss of aluminum through precipitation of amorphous aluminum hydroxides that rapidly form at the high $\mathrm{pH}$ of the stream water once dissolved aluminum enters the stream (Broshears and others, 1996). Upstream from Capulin Canyon the streambed becomes coated with aluminum hydroxide and this likely indicates the beginning of the ground-water discharge zone (fig. 3). Half of the calculated concentrations, however, were within the range of sampled inflow concentrations.

\section{Manganese}

Manganese is derived from the acid weathering of gangue minerals, principally rhodocrosite and high-manganese carbonate. Thus, manganese loading (fig. 14) occurred at many of the same locations as aluminum loading (fig. 13). Once manganese was released to the stream, it mostly occurred as dissolved rather than colloidal manganese (fig. $14 \mathrm{~A})$, which is consistent with the behavior of manganese observed in other streams affected by acid rock drainage (Brown and Glynn, 2003; Davis and others, 1991; Kimball and others, 1995; Laxen and others, 1984). Without a substantial loss of manganese load, the calculated inflow concentrations are closer to concentrations sampled in wells than they were for aluminum (fig. 10C). The greatest distinction of manganese loading in 2001 was the substantial load from the Cabin Springs area (fig. 14B). This area included not only Cabin Springs but also seeps from manganocrete stream banks just downstream from Cabin Springs. This substantial load did not occur in 2002, as noted above, but the large increase in manganese load in the Capulin Canyon section did occur in both years (fig. 

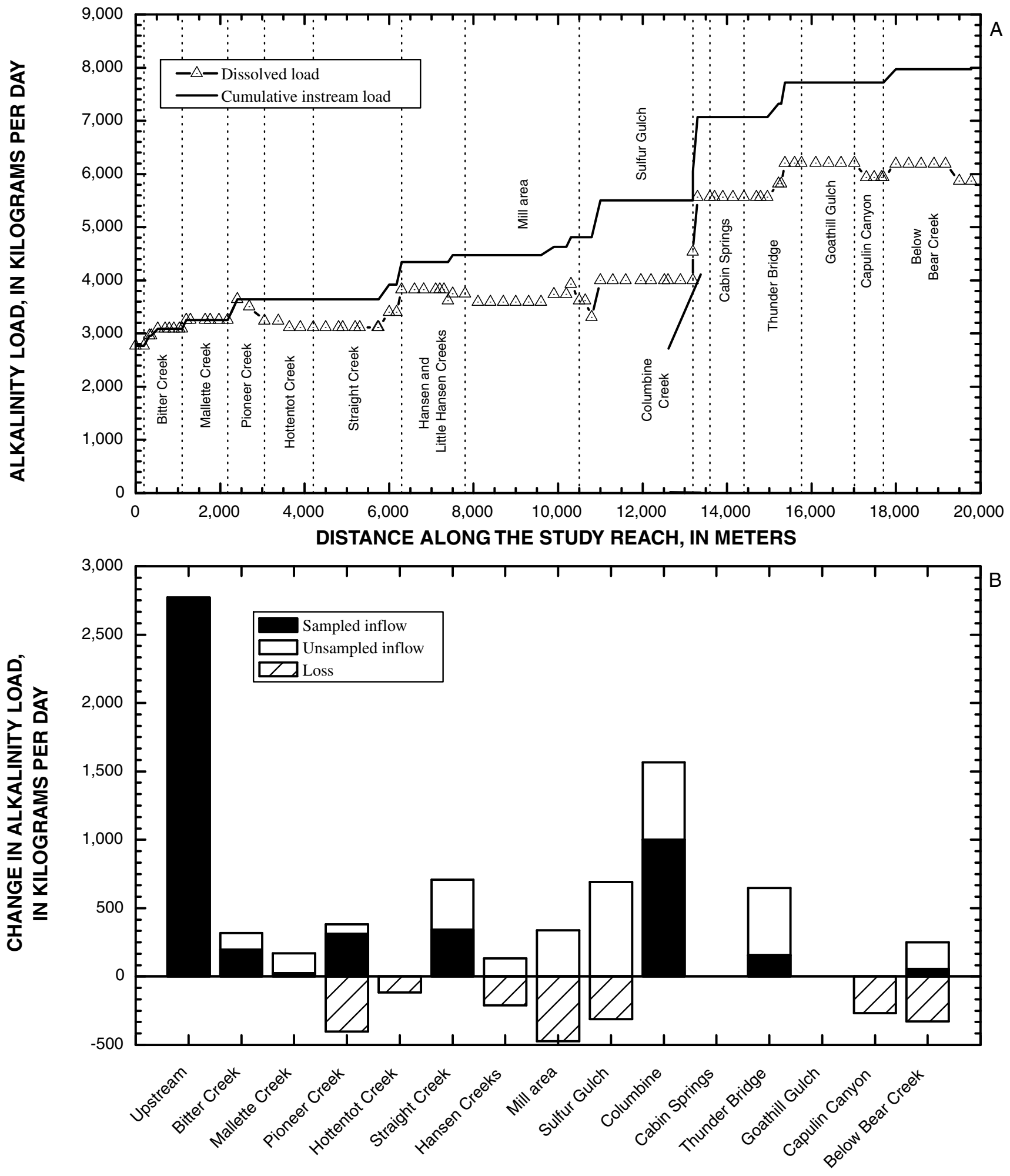

SECTION

Figure 11. Variation of $(A)$ alkalinity load with distance along the study reach and $(B)$ change in alkalinity load for individual sections along the Red River, New Mexico, August 2001. 

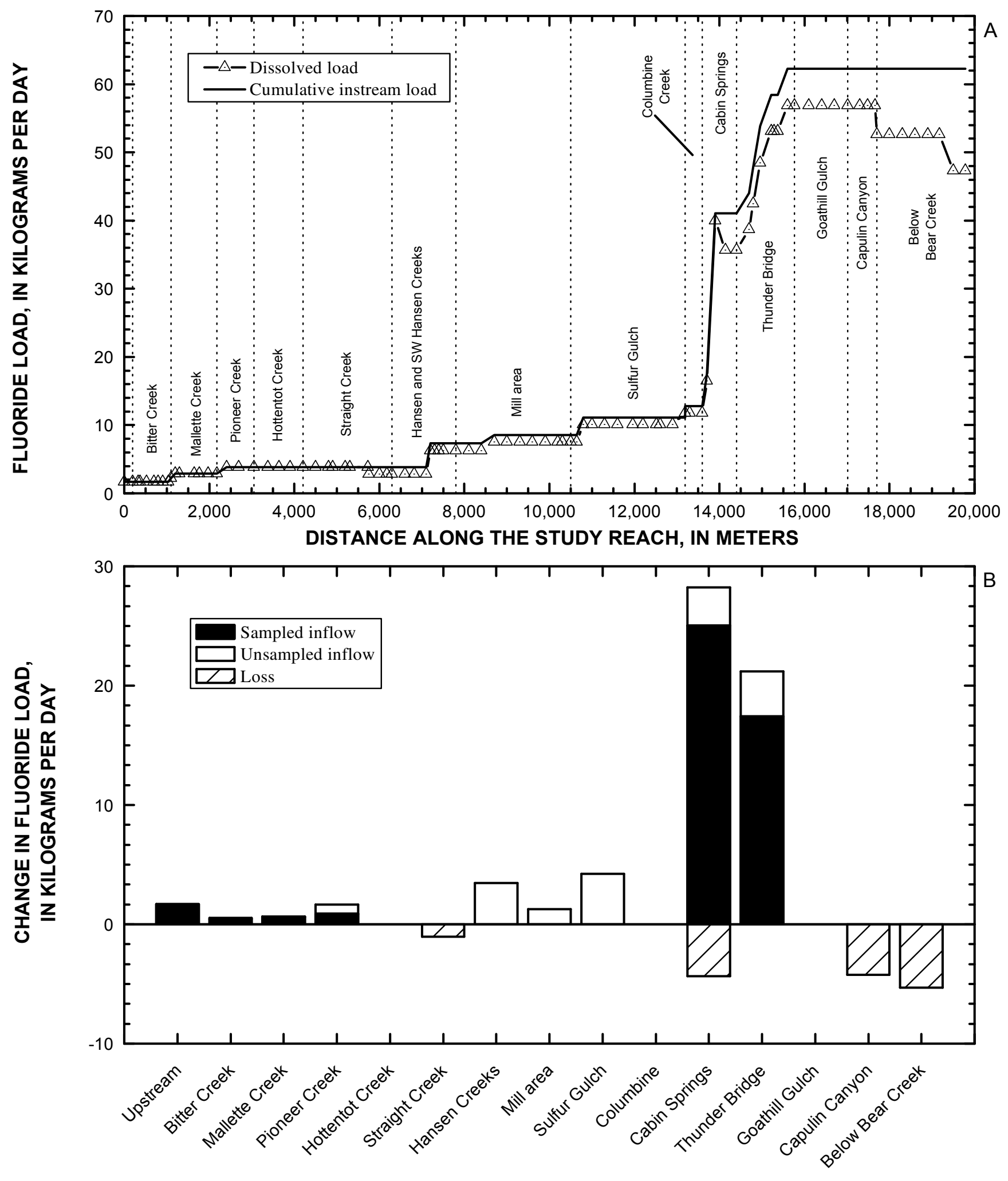

SECTION

Figure 12. Variation of (A) fluoride load with distance along the study reach and (B) change in fluoride load for individual sections along the Red River, New Mexico, August 2001. 

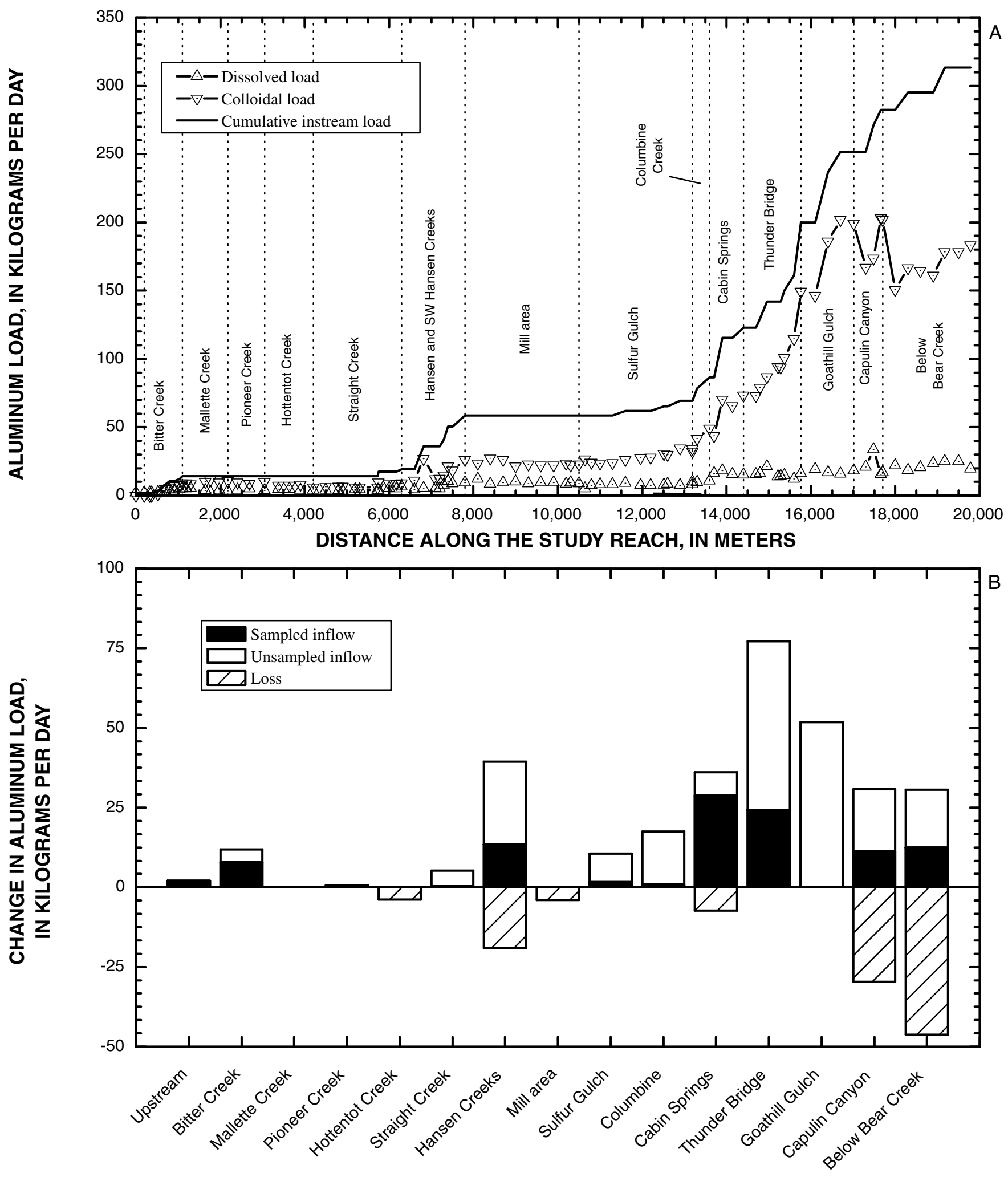

SECTION

Figure 13. Variation of (A) aluminum load with distance along the study reach and (B) change in aluminum load for individual sections along the Red River, New Mexico, August 2001. 

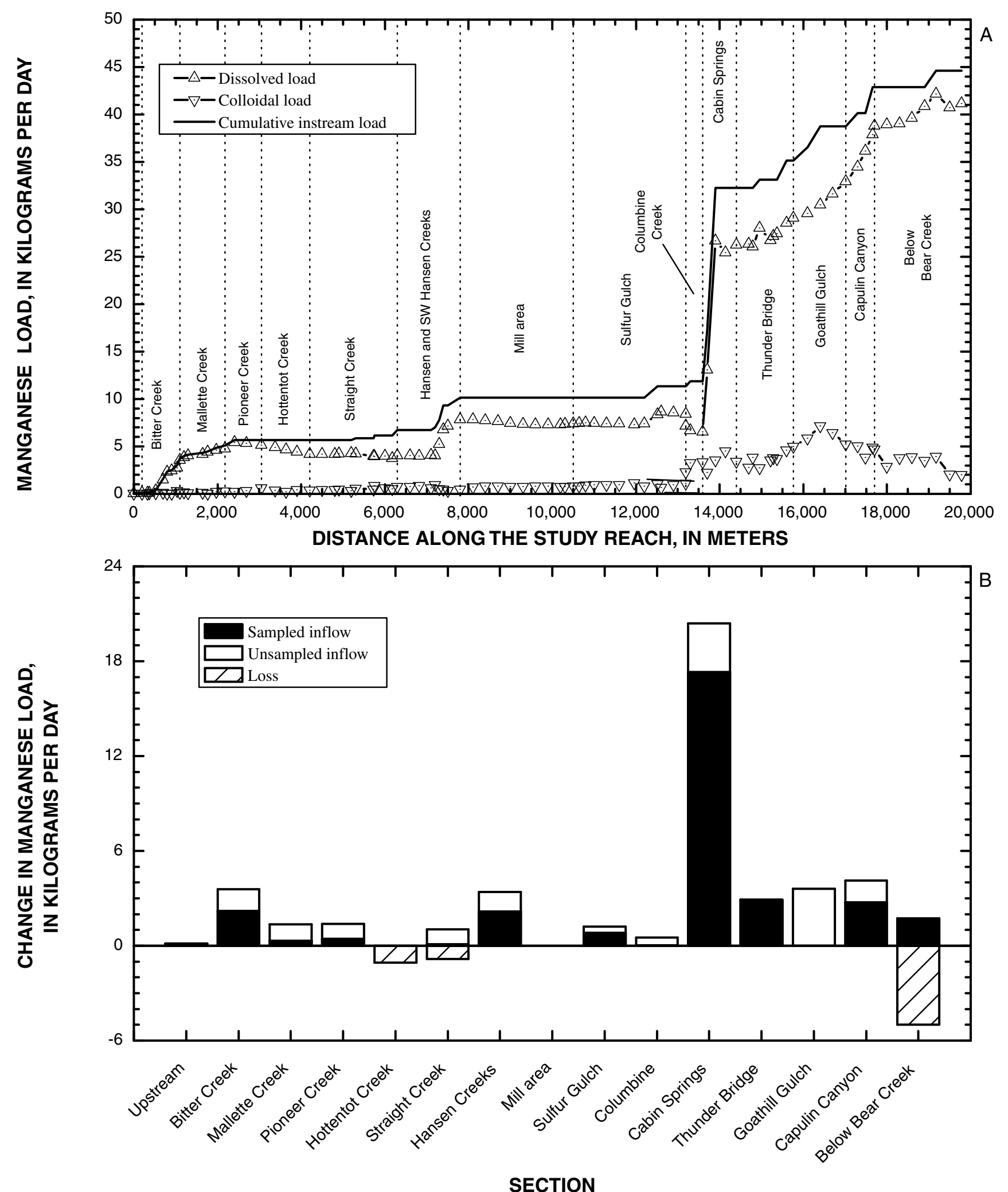

Figure 14. Variation of (A) manganese load with distance along the study reach and (B) change in manganese load for individual sections along the Red River, New Mexico, August 2001. 

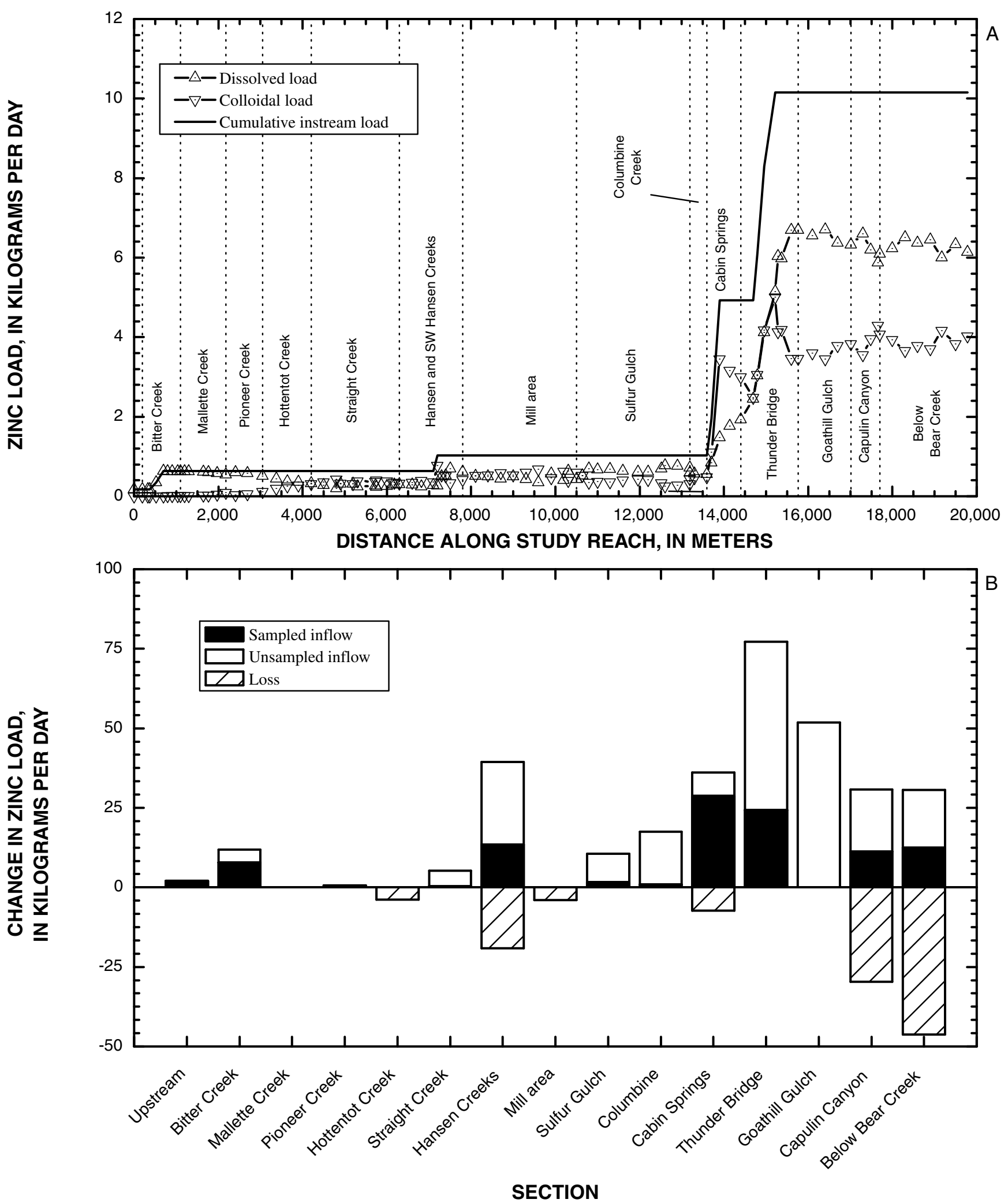

Figure 15. Variation of $(A)$ zinc load with distance along the study reach and $(B)$ change in zinc load for individual sections along the Red River, New Mexico, August 2001. 
7). Loading of manganese from ground-water discharge zones downstream from Columbine Creek was almost three times greater than loading from all the sections upstream from Columbine Creek. Part of the greater manganese (and zinc, fig. 15) loading could result from an increase in the manganese and zinc content of alteration and gangue minerals in these downstream sections (Plumlee and others, 2005).

\section{Zinc}

The pattern of zinc loading (fig. 15), while similar to that of manganese (fig. 14), differed in two respects. First, the sharp increase in manganese at Cabin Springs did not occur with zinc. Second, downstream from Cabin Springs, the loading of zinc was more gradual and widespread (fig. 15A) than that of manganese. Differences in these two patterns may represent spatial differences in the mineralogy of alteration zones; some zones likely had greater amounts of manganesebearing minerals than others (Plumlee and others, 2005). These differences in loading patterns also imply that multiple sources contribute to the loading of manganese and zinc along the study reach.

\section{Implications for Mined versus Unmined Sections}

Because mass loading principally occurred at the groundwater discharge zones rather than at the outlets of individual study-reach sections, the comparison between mined and unmined sections is not simple. Loading from the middle ground-water discharge zone likely represents the combined loading from Hottentot, Straight, Hansen, and southwest Hansen Creeks, all of which are unmined sections with alteration scars. Inflow samples of water from this zone included several from inflow group 3, but none from inflow group 4. Water in the Thunder Bridge and Capulin Canyon sections, on the other hand, included several samples from inflow group 4. The quantity of metal loading in these lower ground-water discharge zones is much greater than from the middle zone. Thus, distinctions in chemistry and loading quantity occurred between the middle and lower ground-water discharge zones. Data from these mass-loading studies cannot distinguish the exact causes of the differences between these discharge zones, but the increase in loading and the change in chemical character are consistent with a possible effect of mining. Inflow chemistry and loading in sections that could potentially be affected by mining clearly differ from that of sections upstream that only are affected by unmined scars.

\section{Summary and Conclusions}

Application of tracer-injection and synoptic-sampling methods in field-scale experiments has quantified the chemical variation of stream and inflow samples and the mass loading along a 20-km reach of the Red River, New Mexico. Detailed synoptic sampling indicated that inflows to the Red River did not coincide with the topographic outlets of most of the tributary catchments along the study reach. Instead, inflows mostly occurred at ground-water discharge zones, including an upstream zone near the town of Red River (324 m - 1,640 $\mathrm{m})$, a middle zone near Hansen and southwest Hansen Creeks $(6,300 \mathrm{~m}-7,500 \mathrm{~m})$, and five downstream zones extending from Portal and Cabin Springs all the way to Bear Creek. Classification of inflow and stream samples by cluster analysis indicated distinct chemical differences among the inflow samples. Four groups of inflow samples represented distinct chemical compositions that may represent the extent of mixing with alluvial aquifer water and, to some extent, the interaction of water with alteration mineral assemblages that may vary in composition along the study reach. Samples that had the greatest extent of mixing with alluvial aquifer water or interaction with alteration minerals (inflow group 4) only occurred in ground-water discharge zones in the Thunder Bridge and Capulin Canyon sections, suggesting a chemical distinction between inflows upstream and downstream from the mine. Among stream samples, five chemical signatures represented both temporal and spatial differences. Temporally, there were differences among stream samples collected at the same locations in 2001 and 2002, most likely because of lower streamflow in 2002 and changes in pumping from the alluvial aquifer by the mine operations. Spatially, there were three locations where the chemical character of stream water changed substantially. The first change occurred at the upper ground-water discharge zone, the second at the middle ground-water discharge zone, and the location of the third change was between Cabin Springs and the Thunder Bridge area (between 13,900 $\mathrm{m}$ and $14,790 \mathrm{~m}$ in 2001 and at 15,221 $\mathrm{m}$ in 2002). Changes in the chemical character at the Cabin Springs area only occurred in 2001 because pumping of the alluvial aquifer water in 2002 and the lower streamflow from drought conditions diminished the discharge. Changes in the Thunder Bridge and Capulin Canyon sections occurred in both years.

These changes in chemical character closely correspond to the profiles of mass loading that indicate the importance of metal and sulfate loading at the ground-water discharge zones. The upper discharge zone likely represents the input of Bitter Creek where there was some historical mining. The middle ground-water discharge zone could represent discharge from the Hottentot and Straight Creek sections in addition to the Hansen and southwest Hansen sections, where the zone occurs. Finally, the substantial loads entering the Red River in the downstream ground-water discharge zones most likely represent input from sections starting at the Sulfur Gulch section on downstream. Loading in the Thunder Bridge section was the greatest among all the sections in the study reach for most of the metals and sulfate. The greater loads and distinct inflow chemistry, in part, correspond to variations in alteration type and regional mineralogy, but also may represent a greater extent of mixing with water in the alluvial aquifer. Locations of emerging alluvial ground water, and thus mass loading to the stream, mostly correspond to geomorphic controls on the 
alluvial aquifer (Kirk Vincent, U.S. Geological Survey, written commun., 2005).

Ground-water discharge from the middle zone principally represents drainage from unmined sections along the study reach. The chemical character of discharge from the Cabin Springs, Thunder Bridge, and Capulin Canyon sections differed from the upper and middle discharge zones. This upstream-downstream distinction could indicate a difference between drainage from mined and unmined areas. Although regional variation in alteration mineralogy has been observed, the upstream-downstream difference in chemistry combined with the large increase in the quantity of metal loading downstream is consistent with a mining impact.

\section{References Cited}

Ball, J.W., Runkel, R.L., and Nordstrom, D.K., 2005, Questa baseline and pre-mining ground-water quality investigation. 12. Geochemical and reactive-transport modeling based on low-flow and snowmelt tracer studies for the Red River, New Mexico: U.S. Geological Survey Scientific Investigations Report 2005-5149, 68 p.

Barnard, W.R., and Nordstrom, D.K., 1982, Fluoride in precipitation. I. Methodology with the fluoride ion-sensitive electrode: Atmospheric Environment, v. 16, p. 99-103.

Barringer, J.L., and Johnsson, P.A., 1989, Theoretical considerations and a simple method for measuring alkalinity and acidity in low-pH waters by gran titration: U.S. Geological Survey Water-Resources Investigations Report 89-4029, $35 \mathrm{p}$.

Bencala, K.E., and McKnight, D.M., 1987, Identifying instream variability: Sampling iron in an acidic stream., in Averett, R.C., and McKnight, D.M., eds., Chemical Quality of Water and the Hydrologic Cycle: Chelsea, Michigan, Lewis Publishers, Inc., p. 255-269.

Bencala, K.E., McKnight, D.M., and Zellweger, G.W., 1990, Characterization of transport in an acidic and metal-rich mountain stream based on a lithium tracer injection and simulations of transient storage: Water Resources Research, v. 26, p. 989-1000.

Besser, J.M., Brumbaugh, W.G., May, T.W., Church, S.E., and Kimball, B.A., 2001, Bioavailability of metals in stream food webs and hazards to brook trout (Salvelinus fontinalis) in the upper Animas River watershed, Colorado: Archive of Environmental Contamination and Toxicology, v. 40, p. 48-59.

Brinton, T.I., Antweiler, R.C., and Taylor, H.E., 1996, Method for the determination of dissolved chloride, nitrate, and sulfate in natural water using ion chromatography: U.S. Geological Survey Open-File Report 95-426A, 16 p.
Broshears, R.E., Bencala, K.E., Kimball, B.A., and McKnight, D.M., 1993, Tracer-dilution experiments and solute-transport simulations for a mountain stream, Saint Kevin Gulch, Colorado: Denver, Colorado, U.S. Geological Survey WaterResources Investigations Report 92-4081, 18 p.

Broshears, R.E., Runkel, R.L., Kimball, B.A., Bencala, K.E., and McKnight, D.M., 1996, Reactive solute transport in an acidic stream: Experimental $\mathrm{pH}$ increase and simulation of controls on $\mathrm{pH}$, aluminum, and iron: Environmental Science \& Technology, v. 30, no. 10, p. 3016-3024.

Brown, J.G., and Glynn, P.D., 2003, Kinetic dissolution of carbonates and Mn oxides in acidic water: Measurement of in situ field rates and reactive transport modeling: Applied Geochemistry, v. 18, no. 8, p. 1225-1239.

Carpenter, R.H., 1968, Geology and ore deposits of the Questa molybdenum mine area, Taos County, New Mexico, in Granton-Sales, J.D., eds., Ore deposits of the United States, 1933-1967: American Institute of Mining Engineers, p. 1328-1350.

Davis, A., 1988, Modeling the fate and transport of $\mathrm{Al}$ and $\mathrm{Zn}$ downstream from an acid mine discharge in Clear Creek, Colorado: Eos, v. 69, p. 370.

Davis, A., Olsen, R.L., and Walker, D.R., 1991, Distribution of metals between water and entrained sediment in streams impacted by acid mine discharge, Clear Creek, Colorado, U.S.A.: Applied Geochemistry, v. 6, p. 333-348.

Friedman, L.C., and Erdmann, D.E., 1982, Quality assurance practices for the chemical and biological analyses of water and fluvial sediments: U.S. Geological Survey Techniques of Water-Resources Investigations book 5, chap. A6, 181 p.

Gale, V.G., and Thompson, A.J.B., 2001, Reconnaissance study of waste rock mineralogy: Questa, New Mexico, Petrography, PIMA spectral analysis and Rietveld Analysis, PetraScience Consultants Inc., 31 p.

Grauch, V.J.S., and Keller, G.R., 2004, Gravity and aeromagnetic expression of tectonic and volcanic elements of the southern San Luis basin, New Mexico and Colorado, in Brister, B.S., Bauer, P.W., Read, A.S., and Lueth, V.W., eds., Geology of the Taos Region: New Mexico Geological Society Guidebook, v. 55, p. 230-243.

Jarrett, R.D., 1992, Hydraulics of mountain rivers, in Yen, B.C., eds., Channel flow resistance centennial of Manning's and Kuichling's rational formula: Littleton, Colorado, Water Resources Publications, p. 287-298.

Kaufman, L., and Rousseeuw, P.J., 1990, Finding groups in data: An introduction to cluster analysis: New York, Wiley, $368 \mathrm{p}$. 
Kilpatrick, F.A., and Cobb, E.D., 1985, Measurement of discharge using tracers: U.S. Geological Survey Techniques of Water-Resources Investigations book 3, chap. A16, 27 p.

Kimball, B.A., Callender, E., and Axtmann, E.V., 1995, Effects of colloids on metal transport in a river receiving acid mine drainage, upper Arkansas River, Colorado, U.S.A.: Applied Geochemistry, v. 10, p. 285-306.

Kimball, B.A., Nimick, D.A., Gerner, L.J., and Runkel, R.L., 1999, Quantification of metal loading in Fisher Creek by tracer injection and synoptic sampling, Park County, Montana, August 1997: U.S. Geological Survey WaterResources Investigations Report 99-4119, 40 p.

Kimball, B.A., Runkel, R.L., and Walton-Day, K., 2003, Use of field-scale experiments and reactive solute-transport modelling to evaluate remediation alternatives in streams affected by acid mine drainage, in Jambor, J.L., Blowes, D.W., and Ritchie, A.I.M., eds., Environmental aspects of mine wastes: Vancouver, British Columbia, Mineralogical Association of Canada, p. 261-282.

Kimball, B.A., Runkel, R.L., Walton-Day, K., and Bencala, K.E., 2002, Assessment of metal loads in watersheds affected by acid mine drainage by using tracer injection and synoptic sampling: Cement Creek, Colorado, USA: Applied Geochemistry, v. 17, no. 9, p. 1183-1207.

Kluth, C.F., and Schaftenaar, C.H., 1994, Depth and geometry of the northern Rio Grande rift in the San Luis Basin, southcentral Colorado: Geological Society of America Special Paper 291, 37 p.

Knight, P.J., 1990, The flora of the Sangre de Cristo Mountains, New Mexico, in Bauer, P.W., Lucas, S.G., Mawer, C.K., and McIntosh, W.C., eds., Tectonic development of the southern Sangre de Cristo Mountains, New Mexico: p. 94-95.

Laxen, D.P.H., Davison, W., and Woof, C., 1984, Manganese chemistry in rivers and streams: Geochimica et Cosmochimica Acta, v. 48, p. 2107-2111.

Lichte, F.E., Goligntly, D.W., and Lamothe, P.J., 1987, Inductively coupled plasma-atomic emission spectrometry: U.S. Geological Survey Bulletin 1770, 10 p.

Lipman, P.W., 1981, Volcano-tectonic setting of tertiary ore deposits, southern Rocky Mountains: Arizona Geological Society Digest, v. 14, p. 199-213.

Lipman, P.W., and Reed, J.C., Jr., 1989, Geologic map of the Latir Volcanic Field and adjacent areas, northern New Mexico: U.S. Geological Survey Map I-1907.

Livo, K.E., and Clark, R.N., 2002, Mapped minerals at Questa, New Mexico, using airborne visibleinfrared imaging: U.S. Geological Survey Open-File Report 02-0026, 10 p.
LoVetere, S.H., Nordstrom, D.K., Maest, A.S., and Naus, C.A., 2004, Questa baseline and pre-mining ground-water quality investigation. 3. Historical ground-water quality for the Red River Valley, New Mexico: U.S. Geological Survey Water-Resources Investigatioins Report 03-4186, 50 p.

Ludington, S., Plumlee, G.S., Caine, J.S., Bove, D.J., Holloway, J.M., and Livo, E., 2004, Questa baseline and pre-mining ground-water quality investigation. 10. Geologic influences on ground and surface waters in the lower Red River watershed, New Mexico: U.S. Geological Survey Scientific Investigations Report 2004-5245, 25 p.

Mathsoft, I., 1999, S-Plus 2000: Modern statistics and advanced graphics: Seattle, Washington, Mathsoft, Inc., 582 p.

McCleskey, R.B., Nordstrom, D.K., Steiger, J.I., Kimball, B.A., and Verplanck, P.L., 2003, Questa baseline and premining ground-water quality investigation. 2. Low-flow (2001) and snowmelt (2002) synoptic/tracer water chemistry for the Red River, New Mexico, U.S. Geological Survey Open-File Report 03-148, 57 p.

McKinnon, T.E., 2002, Sources and seasonal variability of metal and arsenic concentrations in the surface water of the Clark Fork River basin, Montana: University of Montana, unpublished Master's thesis.

Meyer, J.W., and Foland, K.A., 1991, Magmatic-tectonic interaction during early Rio Grande Rift extansion at Questa, New Mexico: Geological Society of America Bulletin, v. 103, p. 993-1006.

Meyer, J.W., and Leonardson, R.W., 1990, Tectonic, hydrothermal and geomorphic controls on alteration scar formation near Questa, New Mexico: New Mexico Geological Society Guidebook, v. 41: p. 417-422.

Naus, C.A., McCleskey, R.B., Nordstrom, D.K., Donohoe, L.C., Hunt, A.G., Paillet, F.L., Morin, R.H., and Verplanck, P.L., 2005, Questa baseline and pre-mining ground-water quality investigation. 5. Well installation, water-level data, and surface- and ground-water geochemistry in the Straight Creek drainage basin, Red River Valley, New Mexico, 200103: U.S. Geological Survey Scientific Investigations Report 2005-5088, $220 \mathrm{p}$.

Nordstrom, D.K., and Alpers, C.N., 1999, Geochemistry of acid mine waters, in Plumlee, G.S., and Logsdon, M.J., eds., The environmental geochemistry of mineral deposits Part A: Processes, techniques, and health issues: Littleton, Colo., Society of Economic Geologists, p. 133-160.

Nordstrom, D.K., and Ball, J.W., 1986, The geochemical behavior of aluminum in acidified surface waters: Science, v. 232 , p. $54-56$. 
Plumlee, G.S., Lowers, H., Koenig, A., and Ludington, S., in press, Questa baseline and pre-mining ground-water quality investigation. 13. Mineral microscopy and chemistry of mined and unmined porphyry molybdenum mineralization along the Red River, New Mexico: Implications for groundand surface-water quality.: U.S. Geological Survey OpenFile Report 2005-1442.

Rantz, S.E., 1982, Measurement and computation of streamflow: Volume 1. Measurement of stage and discharge: U.S. Geological Survey Water-Supply Paper 2175, 200 p.

Rehrig, W.A., 1969, Fracturing and its effects on molybdenum mineralization at Questa, New Mexico: University of Arizona, unpublished Ph.D. thesis.

Robertson GeoConsultants, Inc., 2001, Progress report on task 1.4 of background study - Characterization of surface water of non-mining scar affected watersheds, memo from Chrisoph Wels to Dave Shoemaker: Molycorp Inc., Questa Division, $11 \mathrm{p}$.

Runkel, R.L., Bencala, K.E., Broshears, R.E., and Chapra, S.C., 1996a, Reactive solute transport in streams 1. Development of an equilibrium -based model: Water Resources Research, v. 32, no. 2, p. 409-418.

Runkel, R.L., and Kimball, B.A., 2002, Evaluating remedial alternatives for an acid mine drainage stream: Application of a reactive transport model: Environmental Science \& Technology, v. 36, no. 5, p. 1093-1101.

Runkel, R.L., McKnight, D.M., Bencala, K.E., and Chapra, S.C., 1996b, Reactive solute transport in streams 2. Simulation of a pH modification experiment: Water Resources Research, v. 32, no. 2, p. 419-430.

Schilling, J.H., 1956, Geology of the Questa molybdenum mine area, Taos County, New Mexico: New Mexico Bureau of Mines and Mineral Resources Bulletin 51, 87 p.

Schilling, J.H., 1990, A history of the Questa molybdenum mines, Taos County, New Mexico, in New Mexico Geological Society Guidebook, 41st Field Conference, southern Sangre de Cristo Mountains, New Mexico : New Mexico Geological Society, p. 381-386.

Smolka, L.R., and Tague, D.F., 1989, Intensive water quality survey of the middle Red River, Taos County, New Mexico, September 12 - October 25, 1988: New Mexico Health and Environment Department, 87 p.

South Pass Resources Inc., 1995, Progress report of the geology, hydrology and water quality of mine area, Molycorp Facility, Taos County, New Mexico: Scottsdale, Arizona, South Pass Resources, Inc., 19 p.

Steffen, Robertson, and Kirsten, 1995, Questa molybdenum mine geochemical assessment: Steffen, Robertson, and Kirsten, 10 p.
Stookey, L.L., 1970, FerroZine - A new spectrophotometric reagent for iron: Analytical Chemistry, v. 42, p. 779-781.

Tate, C.M., Broshears, R.E., and McKnight, D.M., 1995, Phosphate dynamics in an acidic mountain stream: Interactions involving algal uptake, sorption by iron oxide, and photoreduction: Limnology and Oceanography, v. 40, no. 5, p. $938-946$.

Taylor, J.R., 1997, An introduction to error analysis: The study of uncertainties in physical measurements, 2nd edition: Sausalito, California, University Science Books, 327 p.

To, T.B., Nordstrom, D.K., Cunningham, K.M., Ball, J.W., and McCleskey, R.B., 1998, A new method for the direct determination of dissolved $\mathrm{Fe}$ (III) concentration in acid mine waters: Environmental Science \& Technology, v. 33, no. 5, p. 807-813.

U.S. Environmental Protection Agency, 2005, Molycorp, Inc. Questa, New Mexico, accessed on November 7, 2005, at http://www.epa.gov/earth1r6/6sf/pdffiles/0600806.pdf

U.S. Geological Survey, 1998, Science for watershed decisions on abandoned mine lands - A review of preliminary results, Denver, Colorado, February 4-5, 1998: U.S. Geological Survey Open-File Report 98-296, 71 p.

U.S. Geological Survey, 2000, Interim report on the scientific investigations in the Animas River watershed, Colorado to facilitate remediation decisions by the U.S. Bureau of Land Management and the U.S. Forest SErvice, March 29, 2000 Meeting, Denver, Colo.: U.S. Geological Survey Open-File Report 00-245, 36 p.

U.S. Geological Survey, 2005, Streamflow for the Nation, accessed on October 1, 2006, at http://nwis.waterdata.usgs. gov/usa/nwis/discharge

URS, 2001, Molycorp Questa Mine site-wide comprehensive hydrologic characterization report: Denver, Colorado, URS, $95 \mathrm{p}$.

Vail Engineering, Inc., 2000, Analysis of acid rock drainage in the middle reach of the Red River, Taos County, New Mexico - Interim Report, Vail Engineering, Inc., 37 p.

Ward, J.R., and Harr, C.A., 1990, Methods for collection and processing of surface-water and bed-material samples for physical and chemical analyses: U.S. Geological Survey Open-File Report 90-140, 71 p.

Wells, S.G., Kelson, K.I., and Menges, C.M., 1987, Quaternary evolution of fluvial systems in the northern Rio Grande rift, New Mexico and Colorado, in Menges, C.M., Enzel, Y., and Harrison, B., eds., Quaternary tectonics, landform evolution, soil chronologies, and glacial deposits - northern Rio Grande rift of New Mexico: Friends of the Pleistocene, p. 55-69. 
Witters, H.E., Van Puymbroeck, S., Stouthart, A.J.H.X., and Bonga, S.E.W., 1996, Physicochemical changes of aluminum in mixing zones: Mortality and physiological disturbances in brown trout (Salmo Trutta L.): Environmental Toxicology and Chemistry, v. 15, no. 6, p. 986-996.

Worman, A., Packman, A.I., Johansson, H., and Jonsson, K., 2002, Effect of flow-induced exchange in hyporheic zones on longitudinal transport of solutes in streams and rivers: Water Resources Research, v. 83, no. 1, p. 2-1-215.

Zellweger, G.W., 1994, Testing and comparison of four ionic tracers to measure stream flow loss by multiple tracer injection: Hydrological Processes, v. 8, p. 155-165.

Zellweger, G.W., Avanzino, R.J., and Bencala, K.E., 1989, Comparison of tracer-dilution and current-meter discharge measurements in a small gravel-bed stream, Little Lost Man Creek, California, U.S. Geological Survey Water-Resources Investigations Report 89-4150, 20 p.

\section{Appendix}

A brief description of the calculations for partitioning around medoids is given in the software manual for S-Plus (Mathsoft, 1999), and the method is fully described in Kaufman and Rousseeuw (1990). Goodness of fit for a particular sample in a particular cluster is described by the calculation of a silhouette value that lies between -1 and 1 . The silhouette value is a measure of how well a particular sample fits within its cluster compared to how well it fits into the nearest neighbor cluster. A silhouette value near 1 means that the object is well classified, a value near zero means the object lies between two clusters, and a value near -1 means that the object is badly classified. For stream and inflow samples, silhouette values are illustrated in figure 16 .

According to the silhouette values, none of the inflow samples were badly classified. The most negative value was -0.1325 , and only 12 of 92 inflow samples had values within plus or minus 0.1325 of zero (fig. 16B). These 12 samples might be considered to fall between clusters, but without more negative silhouette values those samples should not be classified in a different cluster. It is of note that two samples from the Cabin Springs section are among those samples with negative silhouette values in figure 16A, "between" inflow groups 3 and 4. Otherwise, the samples were well classified. Similarly, for stream samples, only 17 of 152 samples had silhouette values that were within plus or minus 0.1688 of zero, with -0.1688 being the most negative silhouette value. No silhouette values were sufficiently negative to consider classification of any stream samples into a different cluster. Therefore, the results are considered acceptable for the discussion of inflow and stream groups.

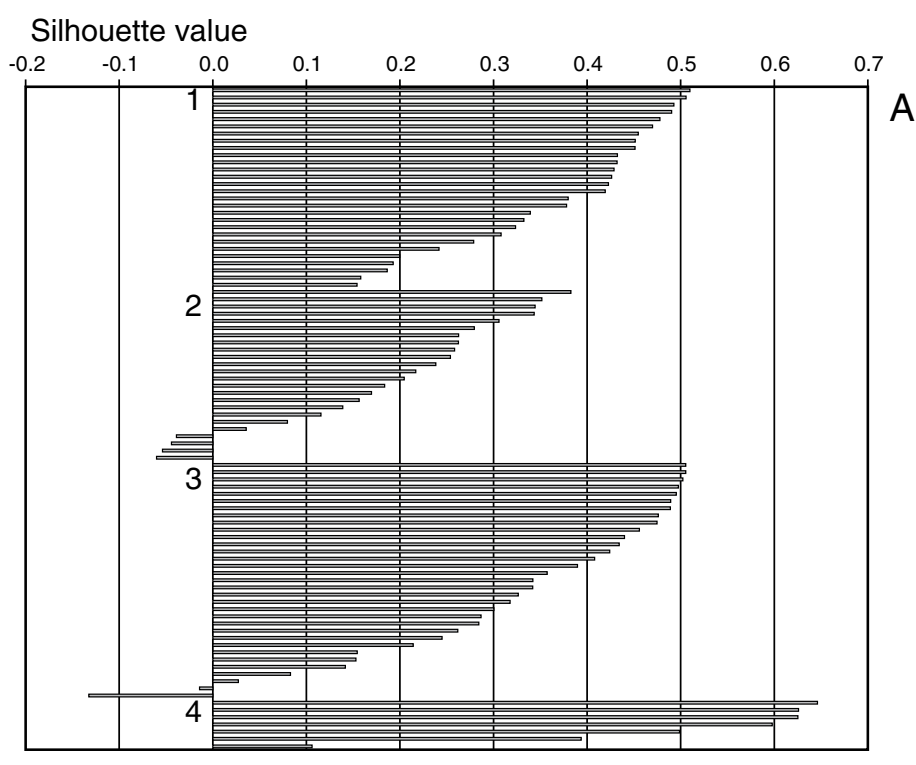

Silhouette value

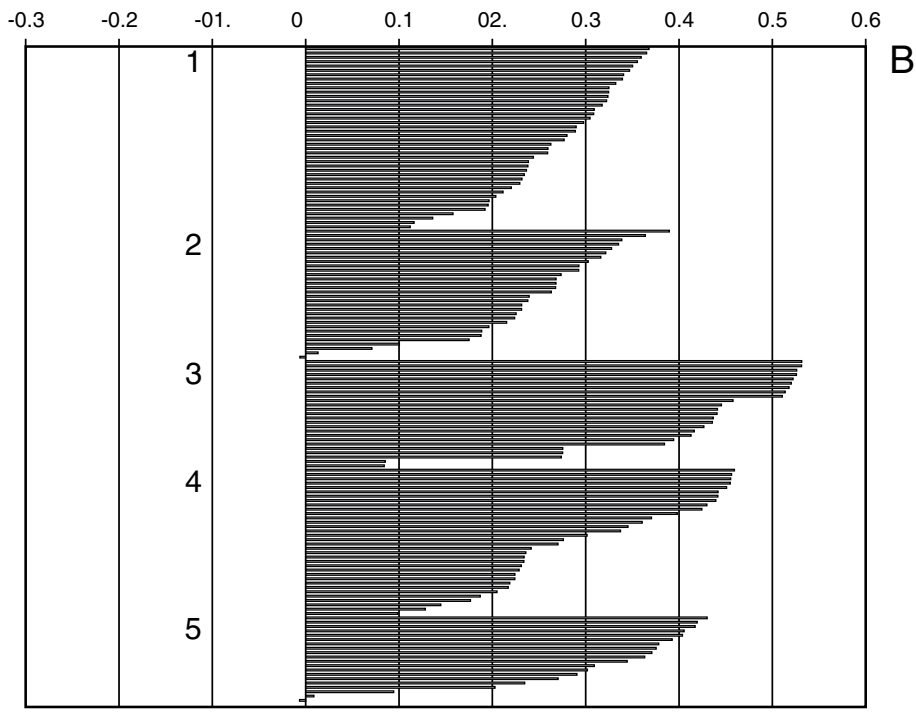

Figure 16. Silhouette values for (A) inflow clusters and (B) stream clusters. Values near zero indicate a sample in between clusters. Only samples with values near minus one are poorly classified. 
Table 1. Downstream distance, source, cluster analysis group, description, sample identification, pH, and estimated discharge for synoptic samples, Red River, New Mexico

[Source: S, stream; RBI, right bank inflow; LBI, left bank inflow; pH, in standard units; NS, not sampled]

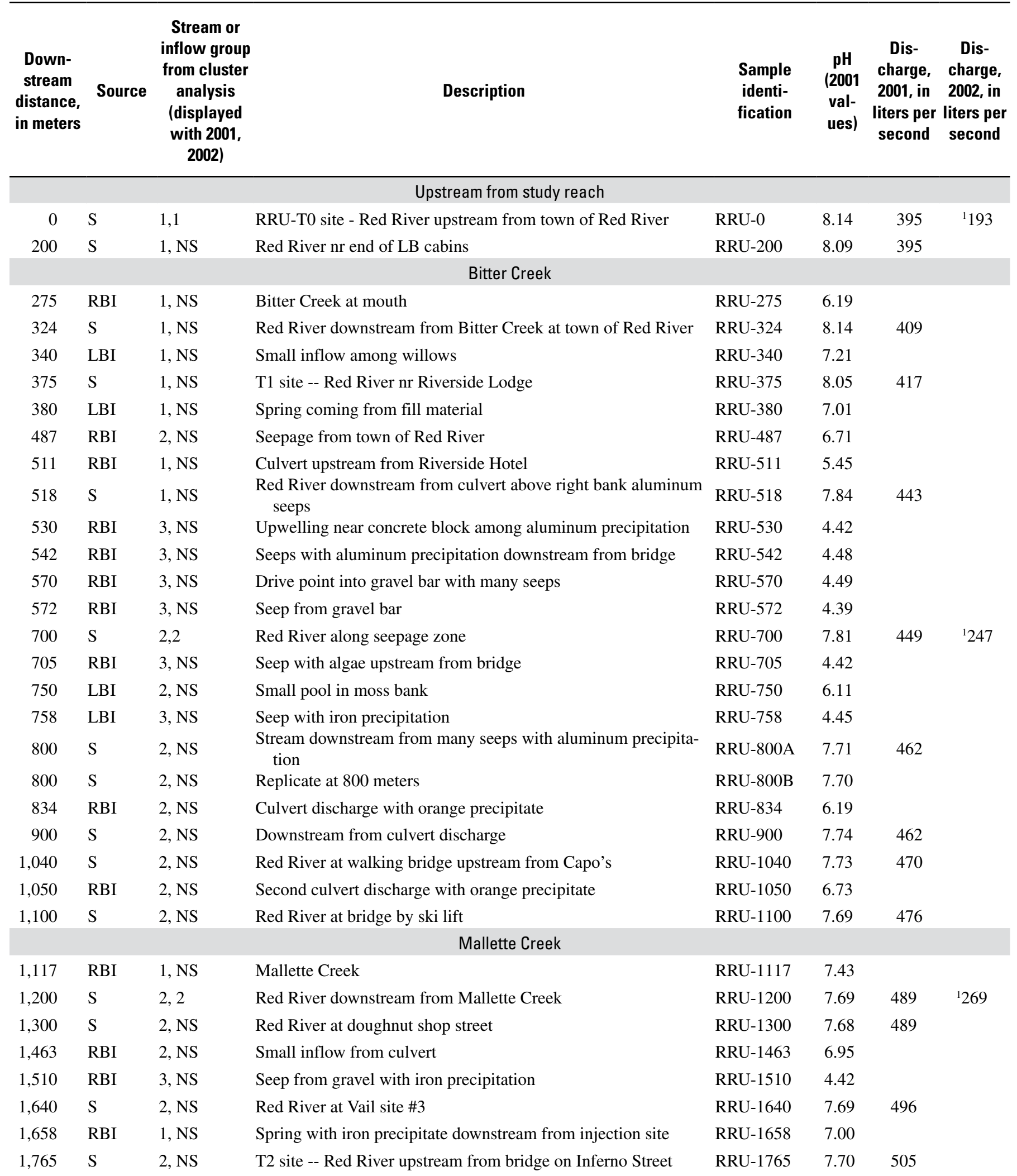


Table 1. Downstream distance, source, cluster analysis group, description, sample identification, $\mathrm{pH}$, and estimated discharge for synoptic samples, Red River, New Mexico—Continued

\begin{tabular}{|c|c|c|c|c|c|c|c|}
\hline 1,975 & $\mathrm{~S}$ & $2, \mathrm{NS}$ & Stream at bridge to large grey apartments & RRU-1975 & 7.73 & 505 & \\
\hline 2,184 & $\mathrm{~S}$ & $2, \mathrm{NS}$ & Red River upstream from Pioneer Creek & RRU-2184 & 7.74 & 505 & \\
\hline \multicolumn{8}{|c|}{ Pioneer Creek } \\
\hline 2,195 & LBI & $1, \mathrm{NS}$ & Pioneer Creek at mouth after diversion & RRU-2195 & 7.74 & & \\
\hline 2,830 & RBI & $1, \mathrm{NS}$ & Pipe discharge returned from campground lake & RRU-2830 & 7.63 & & \\
\hline 3,052 & $S$ & 2,2 & Red River upstream from Hottentot Creek & RRU-3052A & 7.90 & 532 & ${ }^{1} 278$ \\
\hline 3,052 & $\mathrm{~S}$ & 2,2 & Replicate at 3,052 meters & RRU-3052B & 7.78 & & \\
\hline \multicolumn{8}{|c|}{ Hottentot Creek } \\
\hline 3,300 & $\mathrm{~S}$ & $\mathrm{NS}, 2$ & Red River downstream from Hottentot Creek & RRH-3300 & 7.91 & & 307 \\
\hline 3,350 & $\mathrm{~S}$ & 2,2 & T3 site - Red River downstream from Hottentot Creek & RRU-3350A & 7.99 & 518 & 307 \\
\hline 3,350 & $\mathrm{~S}$ & 2,2 & Replicate at 3,350 meters & RRU-3350B & 7.99 & & \\
\hline 3,638 & $\mathrm{~S}$ & 2,2 & Red River at Junebug Campground & RRU-3638 & 8.11 & 503 & 307 \\
\hline 3,900 & $\mathrm{~S}$ & 2,2 & Red River nr Junebug Campground entrance & RRU-3900 & 8.16 & 490 & 307 \\
\hline 5,200 & $\mathrm{~S}$ & 2,2 & Red River upstream from walking bridge to Fawn Lakes & RRU-5200 & 8.21 & 487 & 325 \\
\hline 5,300 & $\mathrm{~S}$ & 2,3 & T4 site -- Red River upstream from Fawn Lakes diversion & RRU-5300 & 8.17 & 492 & 330 \\
\hline 5,652 & LBI & $1, \mathrm{NS}$ & Fawn Lakes return flow & RRU-5652 & 9.01 & & \\
\hline 5,735 & S & 2,2 & $\begin{array}{l}\text { Red River downstream from Fawn Lakes return flow (end of up- } \\
\text { per injection reach) }\end{array}$ & RRU-5735 & 8.30 & 492 & ${ }^{1} 219$ \\
\hline 5,735 & $\mathrm{~S}$ & 2,2 & $\begin{array}{l}\text { Red River downstream from Fawn Lakes return flow (start of } \\
\text { middle injection reach) }\end{array}$ & RRM-5735 & 8.37 & & \\
\hline 6,000 & $\mathrm{~S}$ & 2,3 & T1 Site - Red River near Fawn Lakes campground & RRM-6000 & 8.47 & 562 & 234 \\
\hline 6,175 & $\mathrm{~S}$ & 2,2 & Red River upstream from right bank inflow & RRM-6175 & 8.47 & 562 & 234 \\
\hline 6,209 & LBI & $\mathrm{NS}, 2$ & Seep with algae, opposite toe of Hansen debris flow & RRF-6209 & 7.02 & & \\
\hline 6,214 & RBI & 1,1 & Seep draining toe of Hansen fan & RRM-6214 & 6.87 & & \\
\hline 6,300 & $\mathrm{~S}$ & 2,3 & Red River upstream from Hansen Creek inflows & RRM-6300 & 8.17 & 627 & 269 \\
\hline \multicolumn{8}{|c|}{ Hansen and southwest Hansen Creeks } \\
\hline 6,343 & LBI & 1,1 & Draining upstream of altered cliffs on left bank & RRM-6343 & 6.80 & & \\
\hline 6,600 & $\mathrm{~S}$ & 2,3 & Red River near end of altered zone on left bank & RRM-6600 & 8.20 & 631 & 276 \\
\hline 6,819 & S & 2,3 & Red River between Hansen and southwest Hansen flows & RRM-6819 & 8.15 & 641 & 276 \\
\hline 6,940 & $\mathrm{~S}$ & NS,3 & Red River between culvert and Little Hansen & RRF-6940 & 8.52 & & 278 \\
\hline
\end{tabular}


Table 1. Downstream distance, source, cluster analysis group, description, sample identification, $\mathrm{pH}$, and estimated discharge for synoptic samples, Red River, New Mexico-Continued

\begin{tabular}{|c|c|c|c|c|c|c|c|}
\hline $\begin{array}{c}\text { Down- } \\
\text { stream } \\
\text { distance, } \\
\text { in meters }\end{array}$ & Source & $\begin{array}{l}\text { Stream or } \\
\text { inflow group } \\
\text { from cluster } \\
\text { analysis } \\
\text { (displayed } \\
\text { with 2001, } \\
\text { 2002) }\end{array}$ & Description & $\begin{array}{l}\text { Sample } \\
\text { identi- } \\
\text { fication }\end{array}$ & $\begin{array}{c}\text { pH } \\
\text { (2001 } \\
\text { val- } \\
\text { ues) }\end{array}$ & $\begin{array}{l}\text { Dis- } \\
\text { charge, } \\
\text { 2001, in } \\
\text { liters per } \\
\text { second }\end{array}$ & $\begin{array}{l}\text { Dis- } \\
\text { charge, } \\
\text { 2002, in } \\
\text { liters per } \\
\text { second }\end{array}$ \\
\hline 6,948 & RBI & NS, 1 & Seep at start of large debris flow of southwest Hansen & RRF-6948 & 7.59 & & \\
\hline 7,010 & RBI & $1, \mathrm{NS}$ & Seeps from downstream side of southwest Hansen flow & RRM-7010 & 6.33 & & \\
\hline 7,100 & $\mathrm{~S}$ & 2,3 & Red River downstream from southwest Hansen debris flow & RRM-7100 & 8.04 & 653 & 283 \\
\hline 7,150 & RBI & $\mathrm{NS}, 2$ & Seep with iron precipitate & RRF-7150 & 6.51 & & \\
\hline 7,200 & $\mathrm{~S}$ & 2,3 & $\begin{array}{l}\text { Red River downstream from southwest Hansen debris flow for } \\
\text { mixing }\end{array}$ & RRM-7200 & 8.08 & 658 & 288 \\
\hline 7,270 & RBI & 3,3 & Small spring along right bank & RRM-7270 & 4.23 & & \\
\hline 7,295 & $\mathrm{~S}$ & 2,3 & Red River downstream from grassy spring on right bank & RRM-7295 & 7.94 & 666 & 293 \\
\hline 7,297 & RBI & NS, 3 & Seep with algae from bank & RRF-7297 & & & \\
\hline 7,300 & LBI & 3,3 & Small ditch draining left bank & RRM-7300 & 4.44 & & \\
\hline 7,352 & RBI & 2,2 & Small drainage with iron stain & RRM-7352 & 5.99 & & \\
\hline 7,383 & LBI & NS, 3 & Seep with filamentous algae and aluminum precipitation & RRF-7383 & 4.39 & & \\
\hline 7,377 & S & $\mathrm{NS}, 4$ & Red River downstrem from acidic inflows & RRF-7377 & 7.55 & & 300 \\
\hline 7,395 & $\mathrm{~S}$ & 3,3 & Red River separating inflows in narrowed canyon & RRM-7395 & 7.75 & 668 & 300 \\
\hline 7,400 & LBI & $3, \mathrm{NS}$ & Small seep on left bank & RRM-7400 & 4.11 & & \\
\hline 7,800 & $\mathrm{~S}$ & 3,5 & T2 Site -- Red River at bend near highway & RRM-7800 & 7.91 & 684 & 310 \\
\hline \multicolumn{8}{|c|}{ Mill area } \\
\hline 8,100 & $\mathrm{~S}$ & $3, \mathrm{NS}$ & Red River downstream from large dead fallen tree & RRM-8100 & 8.00 & 684 & \\
\hline 8,400 & $\mathrm{~S}$ & 3,5 & Red River around end of cliffs on right bank & RRM-8400 & 8.08 & 687 & 314 \\
\hline 8,700 & $\mathrm{~S}$ & $3, \mathrm{NS}$ & Red River close to highway & RRM-8700 & 8.11 & 691 & \\
\hline 9,000 & $\mathrm{~S}$ & $3, \mathrm{NS}$ & Red River near riprap along highway & RRM-9000 & 8.16 & 691 & \\
\hline 9,300 & $\mathrm{~S}$ & 3, NS & Red River along straight reach upstream from mill property & RRM-9300 & 8.17 & 691 & \\
\hline 9,600 & S & $3, \mathrm{NS}$ & Red River upstream from mill diversion & RRM-9600 & 8.20 & 691 & \\
\hline 9,900 & $\mathrm{~S}$ & $3, \mathrm{NS}$ & Red River downstream from mill diversion & RRM-9900 & 8.20 & 691 & \\
\hline 10,200 & $\mathrm{~S}$ & 3, NS & Red River nr mill water tank & RRM-10200 & 8.19 & 691 & \\
\hline 10,300 & S & $3, \mathrm{NS}$ & T3 Site -- Red River at bedrock outcrop & RRM-10300 & 8.10 & 691 & \\
\hline 10,360 & RBI & $1, \mathrm{NS}$ & Seep near downstream end of mill yard & RRM-10360 & 6.64 & & \\
\hline 10,500 & $\mathrm{~S}$ & 3, NS & Red River nr triple power pole way up right bank cliffs & RRM-10500 & 8.02 & 697 & \\
\hline \multicolumn{8}{|c|}{ Sulphur Gulch } \\
\hline 10,519 & RBI & $1, \mathrm{NS}$ & Seepage with pond full of algae & RRM-10519 & 6.18 & & \\
\hline 10,572 & LBI & $1, \mathrm{NS}$ & Seepage from along road and Chambers Creek & RRM-10572 & 6.67 & & \\
\hline
\end{tabular}


Table 1. Downstream distance, source, cluster analysis group, description, sample identification, $\mathrm{pH}$, and estimated discharge for synoptic samples, Red River, New Mexico—Continued

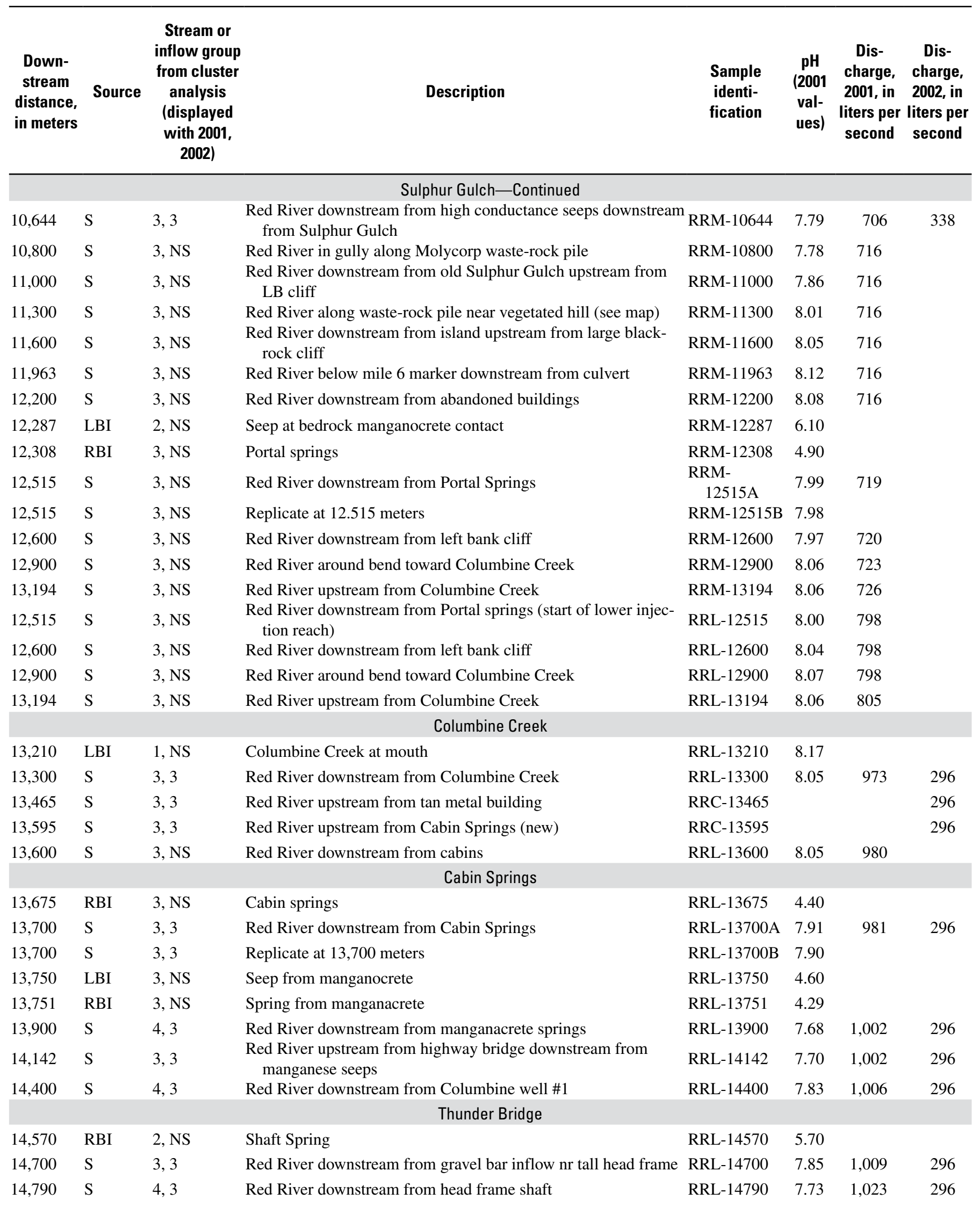


Table 1. Downstream distance, source, cluster analysis group, description, sample identification, $\mathrm{pH}$, and estimated discharge for synoptic samples, Red River, New Mexico-Continued

\begin{tabular}{|c|c|c|c|c|c|c|c|}
\hline $\begin{array}{l}\text { Down- } \\
\text { stream } \\
\text { distance, } \\
\text { in meters }\end{array}$ & Source & $\begin{array}{l}\text { Stream or } \\
\text { inflow group } \\
\text { from cluster } \\
\text { analysis } \\
\text { (displayed } \\
\text { with 2001, } \\
\text { 2002) }\end{array}$ & Description & $\begin{array}{l}\text { Sample } \\
\text { identi- } \\
\text { fication }\end{array}$ & $\begin{array}{c}\text { pH } \\
\text { (2001 } \\
\text { val- } \\
\text { ues) }\end{array}$ & $\begin{array}{c}\text { Dis- } \\
\text { charge, } \\
\text { 2001, in } \\
\text { liters per } \\
\text { second }\end{array}$ & $\begin{array}{l}\text { Dis- } \\
\text { charge, } \\
\text { 2002, in } \\
\text { liters per } \\
\text { second }\end{array}$ \\
\hline 14,800 & RBI & 2, NS & Spring drains willows along left bank & RRL-14800 & 5.83 & & \\
\hline 14,958 & $\mathrm{~S}$ & 4,3 & Red River upstream from spring in willows & RRL-14958 & 7.72 & 1079 & 296 \\
\hline 14,973 & RBI & 2,2 & Draining gravel bar and spring & RRL-14973 & 5.91 & & \\
\hline 15,000 & LBI & 2, NS & Pit in gravel bar & RRL-15000 & 5.98 & & \\
\hline 15,044 & RBI & 2,2 & Spring upstream from Thunder Bridge & RRL-15044 & 6.41 & & \\
\hline 15,221 & S & 4,5 & Red River downstream from Thunder bridge & RRL-15221 & 7.61 & 1,125 & 314 \\
\hline 15,264 & RBI & 1,2 & Seep near start of fan from Goathill Gulch & RRL-15264 & 6.60 & & \\
\hline 15,295 & S & $4, \mathrm{NS}$ & Red River upstream from left bank beaver pond discharge & RRL-15295 & 7.58 & 1,136 & \\
\hline 15,331 & LBI & $1, \mathrm{NS}$ & Discharge from beaver pond & RRL-15331 & 7.18 & & \\
\hline 15,356 & RBI & $1, \mathrm{NS}$ & Small channel of flow from flood plain & RRL-15356 & & & \\
\hline 15,373 & $\mathrm{~S}$ & 4,5 & $\begin{array}{l}\text { Red River downstream from LB beaver pond upstream from } \\
\text { spring } 39\end{array}$ & RRL-15373 & 7.54 & 1,143 & 353 \\
\hline 15,408 & RBI & 3,3 & Spring No. 39 & RRL-15408 & 4.84 & & \\
\hline 15,500 & LBI & 2, NS & Pond in alluvium on left bank & RRL-ALVM & 7.35 & & \\
\hline 15,507 & RBI & NS, 4 & Small spring with filimentous algae & RRC-15507 & 4.25 & & \\
\hline \multicolumn{8}{|c|}{ Capulin Canyon } \\
\hline 17,230 & $\mathrm{~S}$ & 4,5 & Red River nr start of aluminum precipitation zone & RRC-17230 & & & 399 \\
\hline 17,270 & RBI & NS, 3 & Seep with aluminum precipitate & RRC-17270 & 4.05 & & \\
\hline 17,288 & LBI & $\mathrm{NS}, 4$ & Seep from sand with iron staining & RRC-17288 & 4.01 & & \\
\hline 17,300 & S & 4,5 & Red River upstream from small right bank culvert under road & RRL-17300 & 7.82 & 1,214 & 403 \\
\hline 17,480 & $\mathrm{~S}$ & 4,5 & T3 site -- Red River at Vail site 13 & RRL-17480A & 7.80 & 1,216 & 407 \\
\hline 17,480 & $\mathrm{~S}$ & 4,5 & Replicate at 17,480 meters & RRL-17480B & 7.80 & & \\
\hline 17,525 & RBI & NS, 4 & From well in French Drain area & RRC-17525 & 4.11 & & \\
\hline 17,574 & RBI & 3,3 & Discharge from French Drain & RRL-17574 & 4.26 & & \\
\hline 17,595 & RBI & 4,4 & Seep No. 13 with filamentous algae stringers & RRL-17595 & 3.58 & & \\
\hline 17,655 & S & 4,5 & Red River upstream from Capulin Gulch culvert & RRL-17655 & 7.60 & 1,222 & 421 \\
\hline 17,670 & RBI & 4,4 & Pooled seep downstream from engineered Capulin Gulch & RRL-17670 & 3.66 & & \\
\hline 17,700 & S & 4,5 & Red River upstream from Bear Creek inflows & RRL-17700A & 7.57 & 1,223 & 421 \\
\hline 17,700 & $\mathrm{~S}$ & 4,5 & Replicate at 17,700 meters & RRL-17700B & 7.57 & & \\
\hline
\end{tabular}


Table 1. Downstream distance, source, cluster analysis group, description, sample identification, $\mathrm{pH}$, and estimated discharge for synoptic samples, Red River, New Mexico-Continued

\begin{tabular}{|c|c|c|c|c|c|c|}
\hline $\begin{array}{l}\text { Down- } \\
\text { stream } \\
\text { distance, } \\
\text { in meters }\end{array}$ & Source & $\begin{array}{c}\text { Stream or } \\
\text { inflow group } \\
\text { from cluster } \\
\text { analysis } \\
\text { (displayed } \\
\text { with 2001, } \\
\text { 2002) }\end{array}$ & Description & $\begin{array}{l}\text { Sample } \\
\text { identi- } \\
\text { fication }\end{array}$ & $\begin{array}{l}\text { pH } \\
(2001 \\
\text { val- } \\
\text { ues })\end{array}$ & 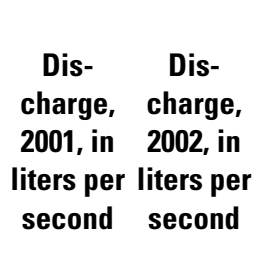 \\
\hline \multicolumn{7}{|c|}{ Downstream from Bear Creek } \\
\hline 17,749 & LBI & $1, \mathrm{NS}$ & Bear Creek at mouth & RRL-17749 & 8.06 & \\
\hline 18,000 & $\mathrm{~S}$ & $4, \mathrm{NS}$ & Red River downstream from Bear Creek inflows & RRL-18000 & 7.80 & 1,233 \\
\hline 18,160 & RBI & $3, \mathrm{NS}$ & Seeps along right bank & RRL-18160 & 4.33 & \\
\hline 18,300 & S & $4, \mathrm{NS}$ & Red River nr Vail site $14 \mathrm{a}$ & RRL-18300 & 7.81 & 1,235 \\
\hline 18,600 & S & $4, \mathrm{NS}$ & Red River downstream from peaks on both sides of canyon & RRL-18600 & 7.68 & 1,235 \\
\hline 18,900 & $S$ & $4, \mathrm{NS}$ & Red River at large RB climbing cliff nr mouth of canyon & RRL-18900 & 7.86 & 1,238 \\
\hline 19,040 & RBI & 3. NS & Pond draining to stream with filamentous algae & RRL-19040 & 4.15 & \\
\hline 19,170 & S & $4, \mathrm{NS}$ & Red River upstream from large diversion structure & RRL-19170 & 7.84 & 1,242 \\
\hline 19,500 & S & $4, \mathrm{NS}$ & Red River nr Forest Service yard & RRL-19500 & 7.89 & 1,181 \\
\hline 19,780 & $S$ & 4,5 & $\begin{array}{l}\text { T4 site -- Red River at U.S. Geological Survey gaging station } \\
08265000\end{array}$ & RRL-19780 & 7.86 & 1,181 \\
\hline
\end{tabular}

${ }^{1}$ Values from velocity-area discharge measurements, not tracer dilution. 


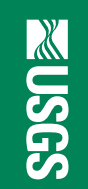

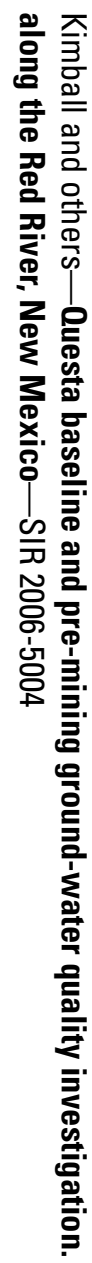

జ

을

言

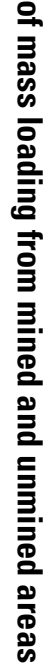

